\title{
Site-Specific Critical Loads of Acid Deposition on Soils in the Edmonton 83H West Map Sheet, Alberta
}

\author{
Salim A. Abboud and Larry W. Turchenek
}

Prepared by:

Alberta Research Council

Edmonton, Alberta

Prepared for:

Environmental Assurance Division

Alberta Environment

February 2009 
ISBN: 978-0-7785-8122-2 (Printed Edition)

ISBN: 978-0-7785-8123-9 (On-line Edition)

www.environment.gov.ab.ca

\section{Disclaimer}

This study was funded by Alberta Environment. Mention of trade names or commercial products does not constitute endorsement or recommendation for use. The author, not the publisher, is responsible for the conclusions and opinions expressed.

This report should be cited as:

Abboud, S.A., and L. Turchenek, 2009. Site Specific Critical Loads of Acid Deposition on Soils in the Edmonton 83H West Map Sheet, Alberta. Prepared by Alberta Research Council for Alberta Environment, Land Monitoring Team.

Edmonton, Alberta. 63 pp, appendices and map.

Any comments, questions or suggestions regarding the content of this document may be directed to:

Land Policy \& Technology Section Environmental Assurance Division Alberta Environment $10^{\text {th }}$ Floor, Oxbridge Place $9820-106$ Street

Edmonton, Alberta T5K 2J6

Fax: (780) 422-4192

For copies of this report, contact:

Alberta Environment Information Centre Main Floor, Oxbridge Place 9820-106 Street

Edmonton, Alberta T5K 2J6

Phone: (780) 427-2700

Email: env.infocent@gov.ab.ca 


\section{TABLE OF CONTENTS}

1.0 INTRODUCTION

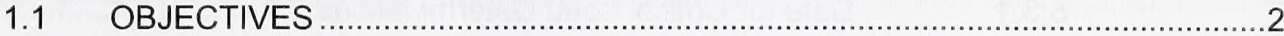

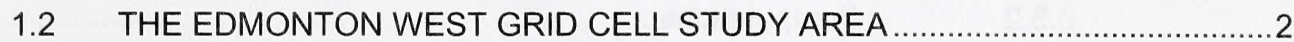

1.3 APPROACH TO CRITICAL LOAD DETERMINATION .....................................

2.0 CRITICAL LOADS AND APPROACHES TO THEIR DERIVATION …..........................

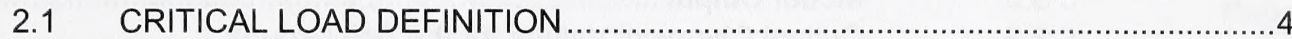

2.2 CRITICAL CHEMICAL CRITERIA AND CRITICAL CHEMICAL VALUES ............4

2.2.1 $\quad$ Soil $\mathrm{pH}$.............................................................................. 4

2.2.2 Calcium to Aluminum and Base Cation to Aluminum Ratios .........6

2.2.3 Base Saturation Percentage ....................................................

2.2.4 Acid Neutralizing Capacity (ANC) of Aquatic Systems ................. 9

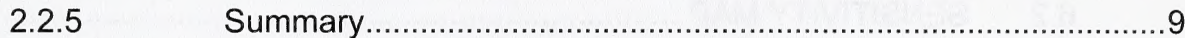

2.3 EMPIRICAL METHOD FOR DERIVATION OF CRITICAL LOADS ....................10

2.4 USE OF MODELS TO DERIVE CRITICAL LOADS .........................................10

2.4.1 Steady State Mass Balance (SSMB) Model ...............................11

2.4.2 Alberta Research Council (ARC) Model .....................................12

2.5 SURFACE WATER ACIDIFICATION MODELS ...............................................

2.6 MODELS USED TO DERIVE CRITICAL LOADS FOR SOILS IN THE EDMONTON WEST STUDY AREA …................................................................... 12

3.0 DATA ACQUISITION AND COMPILATION METHODS

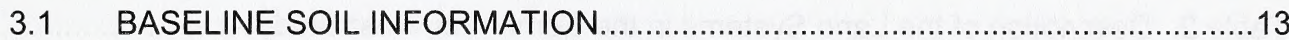

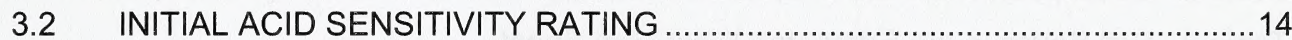

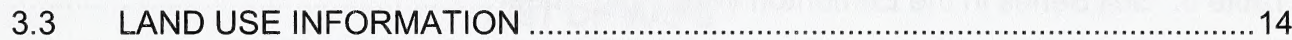

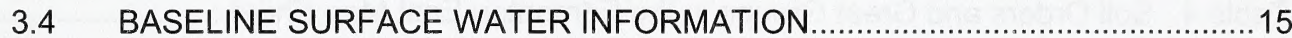

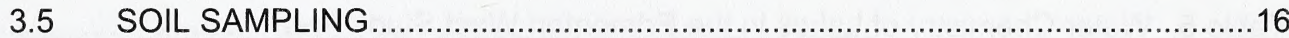

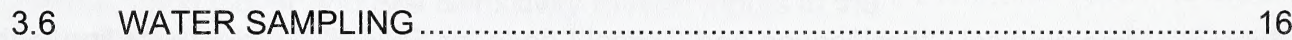

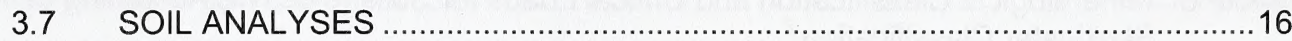

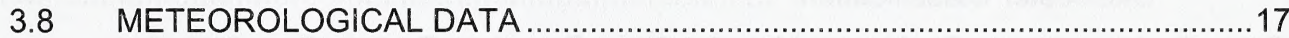

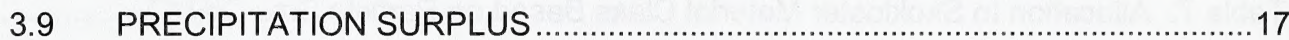

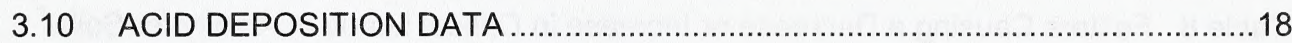

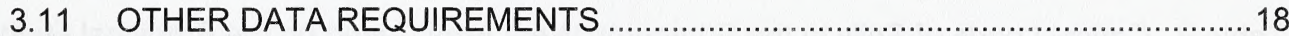

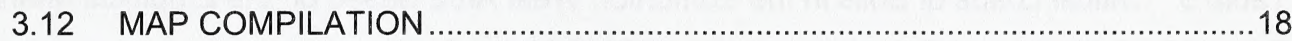

4.0 OVERVIEW OF SOILS AND SURFACE WATERS IN THE STUDY AREA …..............19

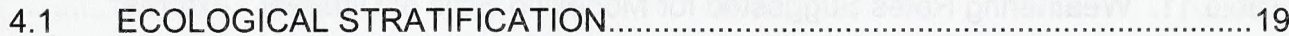

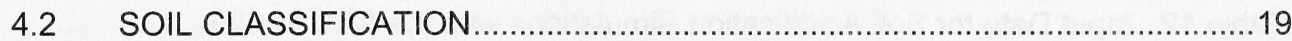

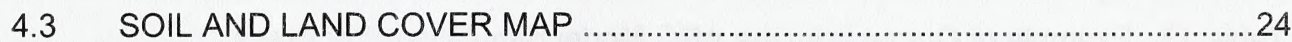

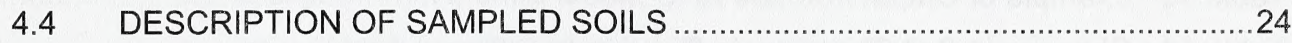

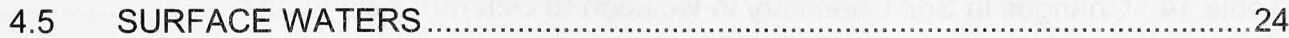

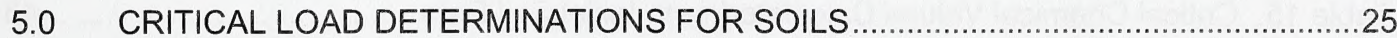

5.1 EMPIRICAL METHOD

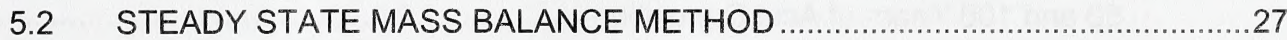

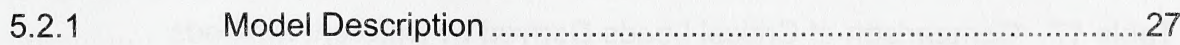


5.2.2 Data for Critical Load Calculations.........................................28

5.2.3 Critical Load Calculations …………........................................

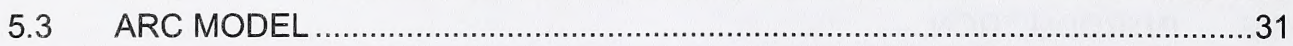

5.3.1 Data for Critical Load Determinations …....................................31

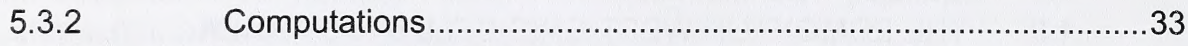

5.3.3 Changes to the ARC Model ……..............................................

5.3.4 Model Execution and Data Outputs ............................................ 38

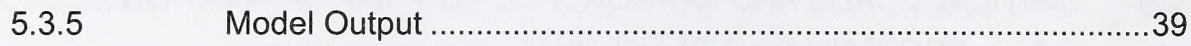

5.3.6 Critical Chemical Values for the Soil Groups ............................43

5.3.7 Critical Load Derivation..........................................................4 44

5.4 COMPARISON OF METHODS OF CRITICAL LOAD DERIVATION ..................46

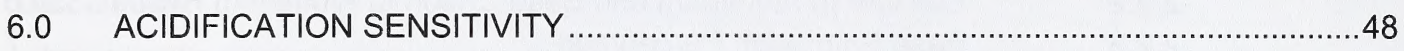

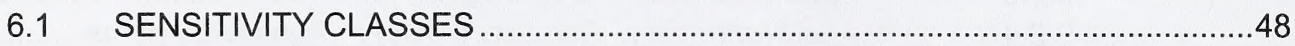

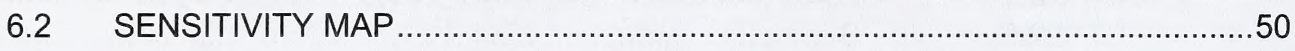

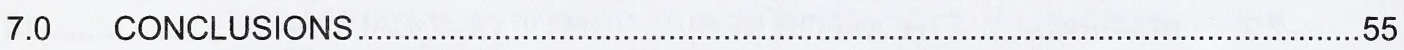

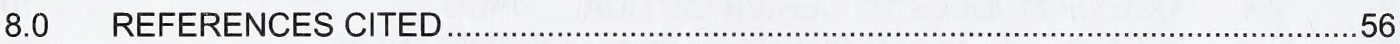

\section{LIST OF TABLES}

Page

Table 1. Proposed Indicators and Thresholds of Stress in Forest and Grassland Ecosystems ..9

Table 2. Description of the Land Systems in the Edmonton West Study Area ..........................20

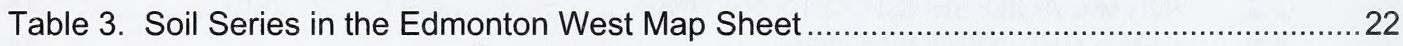

Table 4. Soil Orders and Great Groups in the Edmonton East Map Sheet ...............................2 23

Table 5. Water Chemistry of Lakes in the Edmonton West Study Area .................................... 25

Table 6. Mineralogical Classification and Critical Loads for Soils $(0-0.5 \mathrm{~m})$ According to the

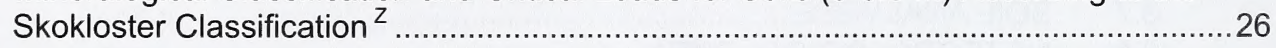

Table 7. Allocation to Skokloster Material Class Based on Particle Size Class ${ }^{z}$........................26

Table 8. Factors Causing a Decrease or Increase in Critical Loads of Acidity for Soils ${ }^{z}$..........26

Table 9. Critical Loads of Soils in the Edmonton West Area Based on the Empirical Method...27

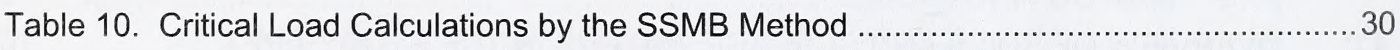

Table 11. Weathering Rates Suggested for Modelling Soils of Different Textures ${ }^{\mathrm{Z}}$.................... 32

Table 12. Input Data for Soil Acidification Simulations with the ARC Model..............................35

Table 13. Example of Output from the ARC Model Simulation Processes …….......................... 38

Table 14. Changes in Soil Chemistry in Relation to Different Acid Inputs ................................. 39

Table 15. Critical Chemical Values Calculated from Initial Soil Data .......................................4 43

Table 16. ARC Model Predictions of Critical Loads for Critical Chemical Values Reached after 50 and 100 Years of Acid Deposition ..................................................................... 45

Table 17. Comparison of Critical Loads Derived by Different Methods .....................................46 
Table 18. Critical Loads and Derived Sensitivity Classes 49

Table 19. Acidification Sensitivity of Land Systems in the Edmonton West Grid Cell. 51

Table 20. Land System Acidification Sensitivity Categories 54

\section{LIST OF FIGURES}

Page

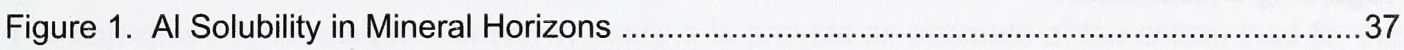

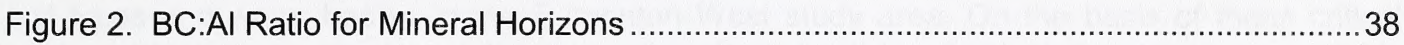

Figure 3. Example of Soil Chemistry Changes Over Time ..................................................42

\section{LIST OF APPENDICES}

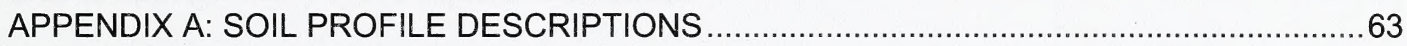

APPENDIX B: SOIL CHEMICAL DATA

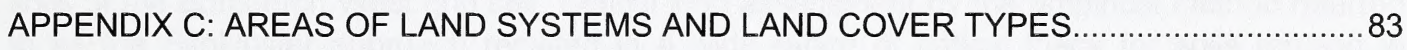

APPENDIX D: LAND AREA ESTIMATION OF SENSITIVITY CLASSES …..............................8

\section{LIST OF MAPS}

Land Systems, Land Cover and Soil Sensitivity to Acid Inputs in the Edmonton West map sheet 


\section{ACKNOWLEDGEMENTS}

This project was undertaken at the request and through the funding provided through the Land Monitoring Team of Alberta Environment. Support in the form of data and information was provided by Environment Canada, Atmospheric Environment Service, Environmental Quality Section, and the Prairie Farm Rehabilitation Administration. Thanks are extended to members of the Clean Air Strategic Alliance's Target Loading Subgroup, and to the many contacts in North America and Europe, for providing reports, reprints, contacts and other information regarding critical loads. 


\section{EXECUTIVE SUMMARY}

The Alberta Acid Deposition Management Framework stipulates that Alberta Environment is responsible for conducting an evaluation of the acid deposition monitoring data in the province, as well as conducting an evaluation of receptor sensitivity. The present study addresses the latter of these two requirements with respect to potentially acid sensitive soils in the Edmonton NTS $83 \mathrm{H}$ West Half map sheet. This map sheet extends from $113^{\circ} \mathrm{W}$ longitude to $114^{\circ} \mathrm{W}$ longitude, and from $53^{\circ} \mathrm{N}$ latitude to $54^{\circ} \mathrm{N}$ latitude.

The objective of this receptor sensitivity study is to provide an estimate of the critical load for the soil types and water bodies in the Edmonton West study area. On the basis of these critical loads estimates, a recommendation regarding the sensitivity of the study area as a whole is provided. The categories Sensitive, Moderate Sensitivity, and Low Sensitivity are applied herein to soils, where the term Sensitive is equivalent to 'High Sensitivity' and Moderate Sensitivity is equivalent to 'Medium Sensitivity' used in some publications.

This area is herein referred to as the Edmonton West grid cell. The areal extent of the study area is approximately 7,376 square kilometres.

Three sensitivity assessment and modelling approaches were applied in examination of the soils of the Edmonton West grid cell. Critical load assessment by the empirical method referred to as the Skokloster approach resulted in a wide range of critical loads for soils ranging in texture from sands to clays. The method is not specifically applied to soil series, but to textural groupings of soils. This approach indicated critical loads as follows: very coarse textured soils 0.2-0.5 kmol ha-1 $\mathrm{yr}^{-1}$; moderately coarse textured soils - 0.5-1.0 $\mathrm{kmol} \mathrm{ha}^{-1} \mathrm{yr}^{-1}$; medium to moderately fine textured soils $-1.0-2.0 \mathrm{kmol} \mathrm{ha}^{-1} \mathrm{yr}^{-1}$; fine textured soils $>2.0 \mathrm{kmol} \mathrm{ha}^{-1} \mathrm{yr}^{-1}$.

The Steady State Mass Balance (SSMB) approach treats the soil as a single compartment to a $0.75 \mathrm{~m}$ depth. The SSMB assessment resulted in relatively high critical loads, as follows: very coarse textured soils - $0.6-0.7 \mathrm{kmol} \mathrm{ha}^{-1} \mathrm{yr}^{-1}$; moderately coarse to medium textured soils - 1.0 $1.6 \mathrm{kmol} \mathrm{ha}^{-1} \mathrm{yr}^{-1}$; medium to moderately fine textured soils $-2.9 \mathrm{kmol} \mathrm{ha}^{-1} \mathrm{yr}^{-1}$; and fine textured soils - $5.6 \mathrm{kmol} \mathrm{ha}^{-1} \mathrm{yr}^{-1}$.

The ARC model utilizes the buffering capacity of soils due to cation exchange as well as to weathering, and assesses changes in soil chemistry over time. The modelling results were expressed as critical loads, which were subsequently applied in deriving sensitivity classes of soils. Two soil series (Primula and Nestow) were determined to be Moderately Sensitive to acid deposition. These same soil series were determined to be potentially Highly Sensitive in a similar study of the Edmonton East Grid Cell, and it is therefore considered that some areas of Highly Sensitive soils occur in the Edmonton West Grid Cell as well. Both these soils are Brunisols developed on very coarse (sandy) materials. Soils of coarse to moderately coarse texture (sand to loamy sand; Helliwell and Mundare soil series) showed Moderate Sensitivity in some soil samples, and Low Sensitivity in others. The differences in sensitivity within the same soil series are thought to be related to the amount of organic matter in the A horizon. The north part of the Edmonton West grid cell is located in a transition area between Chernozemic soils to the south and forested Brunisolic and Luvisolic soils to the north. It is likely that those soils with 
relatively low amounts of organic matter are the most Highly Sensitive to acid deposition. All other soils in the grid cell, being of finer texture and having A horizons rich in organic matter, were rated based on the basis of previous studies as being of Low Sensitivity.

Acidification sensitivity categories of soils examined in this study were compared to sensitivity classes in mapping carried out by Holowaychuk and Fessenden (1987). In the HolowaychukFessenden mapping, the Cooking Lake moraine (i.e., the Islet Upland Land System) was identified as having soils with potentially Moderate Sensitivity, and the Graminia Plain was categorized as being of High Sensitivity. All other soils were categorized as being of Low Sensitivity to acidification. The ARC modelling results suggest that the predominantly Luvisolic soils of the Islet Upland have Low Sensitivity to acidification. Other differences between the Holowaychuk-Fessenden mapping and the ARC model results pertain to the sandy Brunisolic soils of areas such as Redwater Plain, Eldorena Plain and Halfway Lake Dunefield, in the north part of the Edmonton West grid cell. These are mapped as being of Low Sensitivity in the Holowaychuk-Fessenden map. In the current study, some of the soils that characterize these Land Systems were indicated as being Sensitive or of Moderate Sensitivity according to the ARC model.

A map depicting the Land Systems, land cover and soil sensitivity to acid inputs in the Edmonton West map sheet was developed based on the soil sensitivity assessment and on land cover information. Proportions of soil series within Land Systems were estimated from information provided in AGRASID, and from this, the proportions of soils in Moderate to Sensitive (Nestow and Primula), Moderate to Low (Helliwell and Mundare), and Low (all other soils) acidification sensitivity categories were derived. The assignment of Sensitive, Moderate and Low Sensitivity categories was applied only to lands classified as having grassland, tree or shrub cover, on the basis of land use mapping by the Prairie Farm Rehabilitation Administration in 1993-1995. Wetlands, including peatlands, were considered to be of Low Sensitivity. Cultivated soils were not rated, nor were lands categorized as 'Other Lands'. Two sensitivity map units were developed: Low Sensitivity and Low-Moderate-Sensitive Mix.

Portions of three land systems in the Edmonton $83 \mathrm{H}$ West Half grid cell were characterized as having a component of Sensitive and Moderately Sensitive soils. These are the Eldorena Plain, Redwater Plain, and Halfway Lake Dunefield. Other Land Systems likely have small components of Sensitive and Moderately Sensitive soils, but of too low extent to enable mapping at the scale applied in this assessment. Sensitive soils account for $0.65 \%$ and Moderately Sensitive soils account for $2.3 \%$ of the entire grid cell area. As defined in the Acid Deposition Management Framework (Clean Air Strategic Alliance and Alberta Environment 1999), this finding does not support the assignment of this grid cell to a Sensitive or Moderate Sensitivity rating. 


\subsection{INTRODUCTION}

The Acid Deposition Management Framework for the long-term, provincial management of acid deposition was implemented in December, 1999 (Clean Air Strategic Alliance and Alberta Environment 1999). This framework is based upon the current understanding of the levels of acid deposition and the sensitivity of soil and water receptors in the province. Development of this framework included significant stakeholder consultation through Alberta's Clean Air Strategic Alliance.

Critical loads are the foundation of the framework. A critical load is a property of the receptor (soil, water), and is defined as the amount of acid input that can be received by the receptor that will not cause chemical changes leading to long-term harmful change to the receptor.

The province of Alberta is divided into grid cells measuring $1^{\circ}$ latitude $\times 1^{\circ}$ longitude, and each grid cell is categorized as being Sensitive, Moderately Sensitive or of Low Sensitivity to acid deposition based upon soil and water sensitivity databases. A Sensitive cell is defined as a cell within which $5 \%$ or more of the area is categorized as being Sensitive, and to such cells, a critical load of $0.25 \mathrm{kmol} \mathrm{H}^{+} \mathrm{ha}^{-1} \mathrm{yr}^{-1}$ is applied. A Moderately Sensitive cell is defined as a cell within which less than $5 \%$ of the area is categorized as Sensitive, but where the total of Sensitive and Moderately Sensitive areas equals or exceeds $5 \%$ of the cell area. To these Moderately Sensitive cells, a critical load of $0.50 \mathrm{kmol} \mathrm{H}^{+} \mathrm{ha}^{-1} \mathrm{yr}^{-1}$ is applied. The remainder of the grid cells are classified as being of Low Sensitivity to acid deposition and are assigned a critical load of $1.00 \mathrm{kmol} \mathrm{H}^{+} \mathrm{ha}^{-1} \mathrm{yr}^{-1}$.

In addition to critical loads, grid cells have also been assigned target and monitoring loads. Target loads are based upon the critical loads, with the added proviso that target loads be an expression of society's values - in the Alberta framework, target loads are set at $90 \%$ of the critical loads $\left(0.22,0.45\right.$ and $0.90 \mathrm{kmol} \mathrm{H}^{+} \mathrm{ha}^{-1} \mathrm{yr}^{-1}$ for the three sensitivity classes). These target loads are also the environmental objectives as defined in provincial environmental legislation. By establishing target loads below the critical loads, provincial stakeholders and Alberta Environment have established a system of preventing an increase in deposition to the level believed harmful (the critical load). An exceedance of a target load will initiate processes to reduce emissions such that deposition in the exceedance cell is reduced to or below the target load for that cell.

Monitoring loads are also assigned to the sensitivity classes; these are set at $70 \%$ of the critical loads. Exceedance of this load initiates studies of receptor sensitivity and monitoring of deposition - the results of such studies are used to revise the initial assignments of cell sensitivity (and therefore the assigned numerical loads). If the studies confirm model prediction and sensitivity, the cell is watched more closely to ensure that deposition does not increase to the point of a target load exceedance.

The REgional Lagrangian Acid Deposition (RELAD) model (Cheng and Angle 1996; Cheng et al. 1995, 1997) has been used to estimate the amount of acid deposition in Alberta. There are no grid cells currently receiving acid deposition in excess of their assigned critical or target 
loads. However, soils in some parts of the province may be sensitive to levels of acid deposition less than the monitoring load $\left(0.17 \mathrm{kmol} \mathrm{H}^{+} \mathrm{ha}^{-1} \mathrm{yr}^{-1}\right)$ for sensitive ecosystems.

\subsection{OBJECTIVES}

As stipulated in the Alberta Acid Deposition Management Framework, Alberta Environment is responsible for conducting an evaluation of the acid deposition monitoring data in the province, as well as conducting an evaluation of receptor sensitivity. The present study addresses the latter of these two requirements for the Edmonton West map sheet (NTS 83H West Half).

The objective of this receptor sensitivity study is to provide an estimate of the critical load for the soil types and water bodies present in the Edmonton West study area. On the basis of these critical loads estimates, a recommendation regarding the sensitivity of the study area as a whole is provided.

\subsection{THE EDMONTON WEST GRID CELL STUDY AREA}

The study area in this project is the West Half of Map Sheet $83 \mathrm{H}$, located in central Alberta. The boundaries are:

- $113^{\circ} \mathrm{W}$ longitude - east side

- $53^{\circ} \mathrm{N}$ latitude - south side

- $114^{\circ} \mathrm{W}$ longitude - west side, and

- $54^{\circ} \mathrm{N}$ latitude - north side

This area is herein referred to as the Edmonton West study area. All of the City of Edmonton is located within this area. Landmarks and/or towns located at or near the four corners of the grid cell are Pigeon Lake in the southwest, Busby in the northwest, Val Soucy/Redwater River in the northeast, and Bittern Lake in the southeast. Expected areas with Sensitive and Moderate Sensitive soils are the Brunisolic soils in the Devon and Redwater sandy areas, Chernozemic soils in the Peace Hills sandy area in the Millet/Wetaskiwin area, and Luvisolic soils developed on glacial till in the Cooking Lake, Pigeon Lake and Calahoo areas. The areal extent of the study area is approximately 7,376 square kilometres.

\subsection{APPROACH TO CRITICAL LOAD DETERMINATION}

In order to determine the appropriate critical load for the study area, it is necessary to determine the soil types and land uses, to chemically analyze samples collected from the various soil types and water bodies present within the study area, and to estimate the site-specific critical load for each sample using a mathematical receptor model. The approach follows the critical loads determination for the Provost-Esther area reported by Turchenek and Abboud (2001) and for the Edmonton West area (Abboud and Turchenek, 2009).

Critical loads are essentially a measure of the buffering capacity of the system. The buffering capacity can be altered by processes other than deposition of acidic substances from the atmosphere. Agricultural and range management practices may have a large impact on soil chemistry and, therefore, make it difficult to assess the relatively small impacts of acid deposition on soils used for agriculture (crop production) or for livestock grazing. For this 
reason, the emphasis of this project was on soil and water systems that are not, or are minimally, affected by intensive farming and/or range management practices.

The study included a number of components as follows:

- Compilation of available data on soil types, land uses and aquatic systems within the defined area, and generate a map showing this information.

- Collect samples of soil and water to determine the critical load for each soil type/land use/aquatic unit.

- Conduct laboratory analysis of the soil and water samples to obtain model input data.

- Using the ARC and Steady State Mass Balance models, and the laboratory data, estimate the critical load for each sample. Provide an estimate of the critical load for each soil type/land use/aquatic unit, and express in terms of acidification sensitivity categories.

- Generate a map showing the soil acidification sensitivity categories. 


\section{$2.1 \quad$ CRITICAL LOAD DEFINITION}

The term 'critical load' is defined in Alberta as 'the highest load that will not cause chemical changes leading to long-term harmful effects on the most sensitive ecological systems' (Clean Air Strategic Alliance and Alberta Environment 1999). The critical load represents the level of sustained deposition of a substance that will not cause long-term harmful change to an ecosystem. It is thus a property of the ecosystem. The concept of critical loads has been adopted in various countries, especially those of the European Union, as a method for development and implementation of control strategies for air pollutants. Critical load approaches and mapping programs are most extensively developed in Europe, and are described in publications by Downing et al. (1993), Task Force on Mapping (1996), and Posch et al. (1995 1997, 2003). The applicability of critical loads in Alberta has been discussed in Maynard (1996) and Schindler (1996). Based upon these two reports, critical loads have become the foundation of Alberta's Acid Deposition Management Framework (Clean Air Strategic Alliance and Alberta Environment 1999).

\subsection{CRITICAL CHEMICAL CRITERIA AND CRITICAL CHEMICAL VALUES}

The process to establish critical loads depends upon the selection of critical chemical criteria. For soils, these criteria are chemical parameters such as $\mathrm{pH}$, base saturation, aluminum (Al) concentration in soil solution, base cation $(B C)$ concentration in soil solution, and the ratio of $B C$ to Al concentrations. Any or all of these may be selected, and critical loads based upon the inputs chosen may be derived. For water the process is similar, with acid neutralizing capacity (ANC) being the most common critical chemical criterion used.

For each critical chemical criterion, critical chemical values must be established (Sverdrup et al. 1990). Critical chemical values are frequently referred to as thresholds. The criteria selected for this study and the rationale for each selection, and the critical chemical values (thresholds) assigned to each criterion, are discussed below.

\subsubsection{Soil $\mathrm{pH}$}

Soil $\mathrm{pH}$ is defined as the $\mathrm{pH}$ of a solution in equilibrium with soil. It is determined by means of a glass, quinhydrone, or other suitable electrode or indicator usually using distilled water or a salt solution at a specified soil-solution ratio. Various methods can be used to measure soil $\mathrm{pH}$; those particularly relevant in acid deposition impact evaluations are as follows:

$$
\begin{aligned}
& \mathrm{pH}\left(\mathrm{H}_{2} \mathrm{O}\right) \text { - } \quad \text { a soil sample is made into a paste with distilled water, and the } \mathrm{pH} \text { measured } \\
& \text { by insertion of an electrode into the paste; } \\
& \mathrm{pH}\left(\mathrm{CaCl}_{2}\right) \text { - a soil sample is mixed in } 0.01 \mathrm{M} \mathrm{CaCl}_{2} \text { at a 1:2 soil:solution ratio (w:v), and } \\
& \text { the } \mathrm{pH} \text { is measured with a glass electrode dipped into the solution; } \\
& \mathrm{pH} \text { (paste) - a saturated paste of soil in water is filtered, and the } \mathrm{pH} \text { of the filtrate is } \\
& \text { measured with a glass electrode; and, } \\
& \mathrm{pH} \text { (solution) - soil solution is extracted in situ, and the } \mathrm{pH} \text { of the solution is measured with a } \\
& \text { glass electrode. }
\end{aligned}
$$


Theoretically, the $\mathrm{pH}$ (solution) measure provides the most realistic indication of the $\mathrm{pH}$ environment of plant roots. However, $\mathrm{pH}$ (solution) is the most difficult to obtain due to the need for in situ extraction equipment and due to the time required to obtain sample for the $\mathrm{pH}$ measurement.

The closest estimates of the $\mathrm{pH}$ of solution in situ, particularly for soils having low soluble ion content, as reflected by low electrical conductivity are provided by $\mathrm{pH}\left(\mathrm{H}_{2} \mathrm{O}\right)$ and $\mathrm{pH}$ (solution) (Hendershot et al. 1993). However, accuracy and reproducibility by these methods are difficult to attain because of various factors that can affect the measurement, including soil:solution ratio, position of the measuring electrode, drying of soil, $\mathrm{CO}_{2}$ concentration, and others. The value obtained may thus not reflect the actual $\mathrm{pH}$ of soil solution; however, close estimates of the $\mathrm{pH}$ in the root environment can be obtained by controlling some factors, particularly the soil:water ratio (e.g., 1:2 weight:volume).

The $\mathrm{pH}$ of soil sample suspended in $0.01 \mathrm{M} \mathrm{CaCl}_{2}$ solution at a fixed soil:solution ratio is a commonly used method to characterize soil $\mathrm{pH}$. This method has several advantages over $\mathrm{pH}\left(\mathrm{H}_{2} \mathrm{O}\right)$, among them being reproducibility even with dried soil samples. The salt solution generally results in a $\mathrm{pH}$ value about 0.5 units lower than that determined in water. Thus, it underestimates the soil solution $\mathrm{pH}$, although it has also been considered to more accurately estimate the $\mathrm{pH}$ at the surfaces of soil particles because the weak salt solution simulates the soil electrolyte concentration adjacent to these surfaces. $\mathrm{pH}\left(\mathrm{CaCl}_{2}\right)$ expresses a relationship between hydrogen and other cations in the soil solution (Bache 1980). Thus, it is responsive to changes in the concentrations of base cations relative to hydrogen, and as such can be useful in monitoring because it would decrease as base cations are lost from soils. Miewes et al. (1986) also noted that $\mathrm{pH}\left(\mathrm{CaCl}_{2}\right)$ is the more appropriate $\mathrm{pH}$ measure for characterizing the buffer range of a soil. Measurement of $\mathrm{pH}\left(\mathrm{CaCl}_{2}\right)$ is most commonly applied at a 1:2 soil:solution ratio (Kalra and Maynard 1991). The $\mathrm{pH}\left(\mathrm{CaCl}_{2}\right)$ and $\mathrm{pH}\left(\mathrm{H}_{2} \mathrm{O}\right)$ measures are most commonly used in research and reported in the literature. Different soil acidification models use different $\mathrm{pH}$ measures. Consequently, it is important to indicate which measure is used.

Ulrich et al. (1984) suggested that a soil $\mathrm{pH}\left(\mathrm{H}_{2} \mathrm{O}\right)$ of 4.0 to 4.2 posed a high risk of damage to forest ecosystems, and that there was some risk at $\mathrm{pH}\left(\mathrm{H}_{2} \mathrm{O}\right)$ values greater than 4.2. Low soil $\mathrm{pH}$ is typical of forest soils, but is relatively uncommon in grassland soils. Chernozemic soil pH values are typically in the range of 5.6 to 7.7 (Turchenek et al. 1987). Soils in the range of $\mathrm{pH}\left(\mathrm{H}_{2} \mathrm{O}\right) 5.6$ to 6.0 are sufficiently acidic to cause serious loss in yields of most crops in Alberta (Penney et al. 1977; Hoyt et al. 1981). Turchenek and Abboud (2001), in determining critical loads for the predominantly Chernozemic soils of the Esther area, suggested that the critical chemical value for $\mathrm{pH}$ (4.0 to 4.2) for forest soils is not appropriate for application to grassland soils. Furthermore, the typical range in Chernozemic soil pH values would also suggest that the forest soil criteria are not appropriate for Chernozemic soils under native grassland. Because $\mathrm{pH}$ values below 5.6 represent the lower limit of $\mathrm{pH}$ values associated with Chernozemic soils (and grassland soils in general), and a reduction in pH below 5.6 could trigger changes in microbiological and plant species composition, the critical chemical value for $\mathrm{pH}\left(\mathrm{H}_{2} \mathrm{O}\right)$ of $\mathrm{pH} 5.6$ is applied. This is equivalent to a $\mathrm{pH}\left(\mathrm{CaCl}_{2}\right)$ of about 5.0. 


\subsubsection{Calcium to Aluminum and Base Cation to Aluminum Ratios}

Different threshold levels of $\mathrm{Al}^{3+}$ related to plant health have been suggested (Bloom and Grigal 1985; Ulrich et al. 1984; Levine and Ciolkosz 1988); however, Cronan and Grigal (1995) indicated that although total concentration of $\mathrm{Al}$ in soil solution might appear to be the most straightforward index of potential Al toxicity to plants, this measure usually fails to be closely related to plant health. This may be due to the differential toxicity of the various Al species and to the ameliorative effects of other ions in solution. Reported Al toxicity thresholds for trees have a wide range, from $<40 \mu \mathrm{mol} \mathrm{L}{ }^{-1}$ to $>3,000 \mu \mathrm{mol} \mathrm{L}{ }^{-1}$. However, toxicity has been shown within a much narrower range in terms of the Ca:Al molar ratio (range of 0.2 to 2.5), and risk thresholds are therefore indicated in terms of this latter measure.

Cronan and Grigal (1995) reviewed Ca:Al ratios and other properties as indicators of stress in forest ecosystems and suggested a multiple assessment approach for determining the probability of suffering Al stress. The suggested threshold Ca:Al molar ratio of 1 is commonly applied in setting critical loads for forest soils in European countries (Warfvinge and Sverdrup 1992; de Vries 1993; Task Force on Modelling and Mapping 2004). Little information is available with respect to the significance of $\mathrm{Ca}$ :Al ratios in grassland soils, although the same critical chemical value ( $\mathrm{Ca}: \mathrm{Al}$ of 1 ) has been applied to various types of ecosystems in critical load determinations in Europe (Posch et al. 1997). In some countries, the BC:Al ratio is applied instead of $\mathrm{Ca}: \mathrm{Al}$ because of work showing that $\mathrm{BC}$ :Al correlates more strongly with plant root or shoot damage than Ca:Al. The term ' $B C$ ' in this expression refers to the sum of the molar concentrations of the cations $\mathrm{Ca}, \mathrm{Mg}$ and $\mathrm{K}$.

Sverdrup and Warfvinge (1993) presented a data compilation from the literature showing response curves of growth of seedlings of various tree and ground vegetation species in relation to the $\mathrm{BC}: \mathrm{Al}$ ratio. The $\mathrm{BC}: \mathrm{Al}$ ratios at which growth of various grass species was negatively affected ranged widely from 0.3 to 300 . Of the species listed, only Kentucky bluegrass (Poa pratensis), an introduced species, is found in Alberta grasslands. This species is listed as having a critical $\mathrm{BC}: \mathrm{Al}$ ratio of 250 . Some grasses of the same genus as those found in Alberta (Festuca, Bromus, Agrostis), and some Carices, have ratios ranging from 1 to 45 . Only species of the Poa genus have BC:Al ratios of 250 or greater, while the maximum ratio for all other species is 45 . Sensitivity of species of the Festuca, Poa and Bromus genus to $\mathrm{pH}$ and $\mathrm{Al}$ has also been found by Edmeades et al. (1991).

In the absence of research specific to grasslands in western Canada, it is difficult to select an appropriate $\mathrm{BC}: \mathrm{Al}$ ratio that would be protective of all species. The ratio applied to forest soils of 1.0 appears to be low for grass species. The median value for the range of grasses reported by Sverdrup and Warfininge (1993) is about 10. A critical value of 45 had previously been selected in a study of sensitivity of soils in the Provost-Esther grid cell (Turchenek and Abboud 2001). Most of the soils examined in the Edmonton West grid cell occur in the northern part of the study area where Chernozems are transitional to Brunisolic and Luvisolic, forested soils. A transitional BC:Al ratio might, therefore, be more appropriate for these soils. The grass species median range of 10 (Sverdrup and Warfvinge 1993) is thus suggested as the critical chemical value for Chernozemic soils in the Edmonton West grid cell. However, for purposes of comparison with this suggested critical chemical value for $\mathrm{BC}$ :Al, the examination of critical loads in this study includes derivations of critical loads using ratios of $1,10,45$ and 250. 


\subsubsection{Base Saturation Percentage}

Soil percent base saturation was identified by Cronan and Grigal (1995) and by Miewes et al. (1986) as important in evaluating potential acidification stress on forest ecosystems. While there are various methods of measuring base saturation, the method relevant to threshold limits is based on percent of 'effective cation exchange capacity'. Effective cation exchange capacity (CEC) is defined as the CEC that occurs at field $\mathrm{pH}$, as opposed to CEC measured at a specified $\mathrm{pH}$ (i.e., using a $\mathrm{pH}$ buffered extractant). Effective CEC is measured by extraction of exchangeable cations using a neutral, unbuffered saturating solution such as $\mathrm{NaCl}, \mathrm{KCl}, \mathrm{BaCl}_{2}$ or $\mathrm{NH}_{4} \mathrm{Cl}$. The effective $\mathrm{CEC}$ quantifies the number of negatively charged sites with which cations are associated; the major cations in most soils are $\mathrm{Ca}, \mathrm{Mg}, \mathrm{K}, \mathrm{Na}, \mathrm{Al}, \mathrm{Fe}, \mathrm{Mn}$ and $\mathrm{H}$. Thus;

$$
\begin{aligned}
& \mathrm{CEC}=\mathrm{Ca}+\mathrm{Mg}+\mathrm{K}+\mathrm{Na}+\mathrm{Al}+\mathrm{Fe}+\mathrm{Mn}+\mathrm{H}(\text { expressed as cmoles charge per } \mathrm{kg}) \\
& \text { Base Sat } \%=(\mathrm{Ca}+\mathrm{Mg}+\mathrm{K}+\mathrm{Na}) \times 100 /(\mathrm{Ca}+\mathrm{Mg}+\mathrm{K}+\mathrm{Na}+\mathrm{Al}+\mathrm{Fe}+\mathrm{Mn}+\mathrm{H})
\end{aligned}
$$

$\mathrm{Ca}, \mathrm{Mg}, \mathrm{K}$ and $\mathrm{Na}$ are categorized as basic cations because the reaction between an exchangeable cation and free $\mathrm{H}^{+}$derived from dissociation of water results in generation of hydroxyl $\left(\mathrm{OH}^{-}\right)$. Al, Fe and $\mathrm{Mn}$, on the other hand are categorized as acidic cations, as they react and tie up $\mathrm{OH}^{-}$from $\mathrm{H}_{2} \mathrm{O}$, resulting in release of an equivalent amount $\mathrm{H}^{+}$(McBride 1994).

The measurement of CEC and base saturation according to equations (1) and (2) rely on measurement of each of the individual cations. An independent measure of CEC can also be obtained. When unbuffered $\mathrm{NH}_{4} \mathrm{Cl}$, or other neutral salt solution, is passed through a soil sample, $\mathrm{NH}_{4}{ }^{+}$displaces the exchangeable cations. $\mathrm{The} \mathrm{NH}_{4}{ }^{+}$on the exchange complex is then replaced by $\mathrm{Na}$ by passing a $\mathrm{NaCl}$ solution through the sample, and the amount of $\mathrm{NH}_{4}{ }^{+}$is measured, the quantity of $\mathrm{NH}_{4}{ }^{+}$being equal to the CEC. Base saturation is then calculated as:

$$
\text { Base Sat } \%=(\mathrm{Ca}+\mathrm{Mg}+\mathrm{K}+\mathrm{Na}) \times 100 /(\mathrm{CEC})
$$

Base saturation can also be calculated from an independent estimate of the portion of the exchange attributable to acid cations ( $\mathrm{Al}, \mathrm{Fe}, \mathrm{Mn}$ and $\mathrm{H}$ ). This measure is referred to as the Exchangeable Titrateable Acidity (ETA). Base saturation is then calculated as:

$$
\text { Base Sat } \%=(\mathrm{Ca}+\mathrm{Mg}+\mathrm{K}+\mathrm{Na}) \times 100 /(\mathrm{Ca}+\mathrm{Mg}+\mathrm{K}+\mathrm{Na})+\mathrm{ETA}
$$

All of the above approaches theoretically provide the same base saturation value, although they seldom do so in practice. Different methods are applied in different institutions and countries. The protocol of the UNECE International Cooperative Programme on Integrated Monitoring (UNECE Convention on Long-Range Transboundary Air Pollution 2006) applies methodology according to equation (4) above, although the other approaches are used in other programs (e.g., Miewes et al. 1986). Cation exchange capacity values applied in dynamic modelling of critical loads in Europe are based on measurement in a solution buffered at pH 6.5 (Task Force on Modelling and Mapping 2004). Thus, methodologies differ between monitoring and modelling applications, and it is important that the specific methods be specified. 
For forest ecosystems, a threshold base saturation reduction to a level of $5 \%$ (a critical chemical value of $5 \%$ base saturation) was suggested by Ulrich et al. (1984), while a reduction to $15 \%$ was recommended as a threshold by Cronan and Grigal (1995) on the basis of work by Cronan and Schofield (1990). These threshold values refer to base saturation calculations based on 'effective cation exchange capacity'; that is, cations measured in an extract from a soil sample equilibrated with a neutral salt solution rather than a buffered solution (i.e., Equation 1). A base saturation value of $10 \%$, based on neutral salt exchangeable cation determination, is commonly applied as a critical value in modelling of soil chemistry effects.

Low base saturation is a characteristic of forest soils, and forest soils typically have relatively low $\mathrm{pH}$ values. Grassland soils, however, are characterized by relatively high base saturation and $\mathrm{pH}$ values. Chernozemic soils are the most common grassland soils, with Solonetzic and Vertisolic soils being common associates. A Chernozemic ' $A$ ' horizon is diagnostic for the Chernozemic Order of soils in Canada (Soil Classification Working Group 1998). Among the criteria associated with a Chernozemic A horizon is a base saturation greater than $80 \%$ and dominance of exchangeable $\mathrm{Ca}^{2+}$ on the exchange complex (other criteria apply to Chernozemic soils, but they are not associated with acidification). This $80 \%$ base saturation level is based on measurement by the 'neutral salt' method.

On the Canadian Prairies there is a gradual change in the nature of surface soil horizons from grassland soils in the south to forested soils in the north, where leached (Ae) horizons become more prevalent. A leached Ae horizon is indicative of loss of base cations and decreased $\mathrm{pH}$ in this horizon. There is thus a relationship between vegetation and the type of surface soil, the implication being that vegetation changes as $\mathrm{pH}$ and base saturation decrease. Climate, however, is another major factor that prevents grasslands on the dry prairie from converting to forest vegetation if they become acidified. It might be hypothesized, however, that prairie vegetation assemblages would change in response to acidification, such that more acid tolerant species may become more prevalent. On this basis, therefore, a base saturation of $80 \%$ appears to be an applicable threshold limit for acidification of grassland soils.

As noted above, the $80 \%$ base saturation criterion for Chernozemic soils is based on measurement by the 'neutral salt' method, and an equivalent value based on a 'buffered' CEC measurement is not provided in the Canadian System of Soil Taxonomy (Soil Classification Working Group 1998). In 'Soil Taxonomy' (United States Natural Resources Conservation Service, 1999), the system of soil classification applied in the United States, a base saturation of at least $50 \%$, determined by the ammonium acetate buffered method, is a criterion for definition of a mollic epipedon. The mollic epipedon is similar in definition to the Chernozemic A horizon, which is diagnostic of Chernozemic soils in the Canadian system of soil classification. Consequently, since the ARC model utilizes the base saturation based on a $\mathrm{pH} 7.0$ buffered extraction procedure, a base saturation of $50 \%$ based on an ammonium acetate measurement of CEC could be adopted as a critical chemical value for Chernozemic soils. This is applied together with the $\mathrm{pH}\left(\mathrm{H}_{2} \mathrm{O}\right)$ criterion (Section 2.2.1) as an indicator of acidification effects in this report. Further discussion about application of base saturation to critical load determination is provided in Section 5.3.6. 


\subsubsection{Acid Neutralizing Capacity (ANC) of Aquatic Systems}

Acid neutralizing capacity (ANC) is the ability of a solution to neutralize inputs of strong acid to a pre-selected equivalence. It is calculated as:

$$
[\mathrm{ANC}]=[\mathrm{BC}]-[\mathrm{AN}]=\left[\mathrm{HCO}_{3}^{-}\right]=\left[\mathrm{A}^{-}\right]-\left[\mathrm{H}^{+}\right]-\left[\mathrm{Al}^{\mathrm{n}+}\right]
$$

where, $[B C]$ is the base cation concentration, $[A N]$ is the strong acid anion concentration, $\left[\mathrm{HCO}^{3-}\right]$ is the bicarbonate concentration, $\left[\mathrm{A}^{-}\right]$is the organic anion concentration and $\left[\mathrm{A}^{n+}\right]$ is the sum of all inorganic Al ions. A threshold (critical chemical value) for ANC of $20 \mu \mathrm{eq} \mathrm{L}^{-1}$ has been applied in Scandinavia as a critical chemical value for fish in surface waters (Henriksen et al. 1990), although different ANC values specific to different receptors have also been suggested (Henriksen et al. 1995). The threshold is applied in models used to determine critical loads for surface water bodies; e.g., the Steady State Water Chemistry model and the First-Order Acidity Balance model (Task Force on Mapping 1996).

\subsubsection{Summary}

The threshold or critical chemical value refers to the value of a critical chemical criterion or combination of criteria (e.g. ratios) above or below which no harmful response in a biological indicator is expected to occur. The critical chemical values pertinent to grassland soils and to surface waters that are used in this study are given in Table 1.

\section{Table 1. Proposed Indicators and Thresholds of Stress in Forest and Grassland Ecosystems}

\begin{tabular}{|c|c|}
\hline Critical Chemical Criteria (Indicators) & Critical Chemical Values (Thresholds) \\
\hline \multicolumn{2}{|l|}{ Soils } \\
\hline $\mathrm{pH}\left(\mathrm{CaCl}_{2}\right)-$ Forest Soils ${ }^{2}$ & 3.5 \\
\hline $\mathrm{pH}\left(\mathrm{H}_{2} \mathrm{O}\right)-$ Forest Soils ${ }^{\mathrm{Z}}$ & 4.2 \\
\hline $\mathrm{pH}\left(\mathrm{CaCl}_{2}\right)$ - Grassland Soils ${ }^{Y}$ & 5.0 \\
\hline $\mathrm{pH}\left(\mathrm{H}_{2} \mathrm{O}\right)-$ Grassland Soils $^{\mathrm{Y}}$ & 5.6 \\
\hline Base saturation percentage - Forest Soils ${ }^{x}$ & $<15 \%$ of effective CEC \\
\hline Base saturation percentage - Grassland Soils ${ }^{Y}$ & $<80 \%$ of effective CEC \\
\hline BC:Al ratio - Forest Soils ${ }^{x}$ & $\begin{array}{c}1.0(50 \% \text { risk }) \\
0.5(75 \% \text { risk) } \\
0.2(95-100 \% \text { risk })\end{array}$ \\
\hline BC:Al ratio - Grassland Soils ${ }^{Y}$ & 10 \\
\hline \multicolumn{2}{|l|}{ Surface Water } \\
\hline $\mathrm{ANC}^{\mathrm{W}}$ & $20 \mu \mathrm{eq} \mathrm{L^{-1 }}$ \\
\hline
\end{tabular}

After Uirich et al. (1984)

$\checkmark$ After Turchenek and Abboud (2001)

$\times$ After Cronan and Grigal (1995)

w After Task Force on Mapping (1996) 


\subsection{EMPIRICAL METHOD FOR DERIVATION OF CRITICAL LOADS}

Empirical methods of critical load derivation are based mainly on observation of responses of ecosystem components to acid deposition. In the case of soils, it has been suggested that a basic principle underlying a critical load is that the total input of hydrogen ions to the soil must not exceed the alkalinity produced by the weathering of soil minerals (Nilsson 1986). At a workshop in Skokloster, Sweden, it was concluded that the rate of chemical weathering is the single most important factor governing the soils ability to buffer incoming acidity, and therefore critical loads, for forest soils (Nilsson and Grennfelt 1988).

This mineralogical approach (the Skokloster approach) was adopted with some modifications for critical load determination of soils in the U.K. (Hornung et al. 1995). Texture, drainage, soil thickness and other factors were considered in deriving critical loads in the U.K. Details of the application of this mineralogical approach to the Edmonton West study area are presented in Section 5.1 .

\subsection{USE OF MODELS TO DERIVE CRITICAL LOADS}

Numerous models have been developed to examine soil acidification and to derive critical loads. Modelling approaches comprise two main categories referred to as 'steady-state methods' and 'dynamic modelling'. Within each category, there are varying degrees of sophistication ranging from simple calculations to complex mathematical constructs. The most complex are integrated forest soil models that link soil processes to other processes such as vegetation growth, hydrology and nutrient cycling.

Steady-state models calculate deposition levels that avoid harmful effects to ecosystems that are in steady-state (Task Force on Mapping 1996). Processes such as cation exchange and sulphate adsorption have a finite time scale and therefore cannot be included in steady-state models. Therefore, steady-state models are mainly used for calculation of critical loads over very long periods of time. Two types of steady-state models have been developed for soils. One-layer models, such as the Steady State Mass Balance (SSMB) model consider the soil as a single layer, whereas the multi-layer models consider chemical conditions in different soil layers or horizons. The one-layer SSMB model has been the most commonly applied tool for derivation of critical loads of soils in Europe (Task Force on Mapping 1996).

Dynamic models are a family of more complex models that use various calculations to simulate changes in soil solution or water chemistry due to acid deposition over time. Examples are the MAGIC, SAFE, VSD and SMART models, which have been developed in Europe (UNECE Convention on Long-Range Transboundary Air Pollution 2006), and the ARC model, applied in this report. Calculations of critical loads using these models is not as straightforward as with steady-state models because of the temporal aspect; i.e., it is necessary to determine the acceptability or non-acceptability of chemical changes in soils or waters in relation to a predetermined period of time. Another reason for non-usage is the need for much data required to run some of the dynamic models. Consequently, dynamic models have not been used to a great extent in determining critical loads. However, these models are useful in scenario analysis; i.e., for assessing effects of given deposition levels over a selected period of time, and for determining the effects of different emission abatement strategies. 
Dynamic models are used to calculate the acidification process for an ecosystem through time. Dynamic models, as compared to steady-state models, require more input data of which several parameters are more difficult to obtain. Since an assessment of the time periods involved in acidification responses and recovery from acidification can be made with these models, they are the best tools available for addressing time-dependent scenarios and the impact of episodic events on ecosystems. Several of these models are research tools, and are not available for evaluation and application in Alberta at the present time.

The gradual change with time in the acidification state of the system in response to some change in deposition is calculated with dynamic models. Critical loads can be calculated from different deposition scenarios, and the results can be compared to the critical chemical values (thresholds) for several different critical chemical criteria (e.g., ion exchange, weathering of soil minerals, uptake and cycling of base cations and nitrogen by plants, and soil solution equilibrium chemistry) in the system simultaneously. They use integrated mass balances for substances and differential equations for the rates of different processes. The time-dependent scenarios are obtained by numerical integration of the model subroutines advancing in small time-steps.

Various assumptions are made in the equations within the dynamic models. It is generally assumed that the CEC is constant over time and that a certain ion exchange equilibrium applies (Gapon or Gaines-Thomas exchange equation), and aluminum is assumed to be in continuous equilibrium with a mineral of the same composition as gibbsite (de Vries 1991). Some models assume sulphate adsorption to be negligible or at steady-state, while others have sulphate adsorption as a major process.

Some soil models are subroutines of more complex models used for impact studies and critical load determinations for aquatic systems. Sverdrup et al. (1990) suggested that several models be examined before choosing a model for soil evaluations and critical load calculations. The models differ somewhat in their basic principles, and have different limitations connected to their use and to the interpretation of their results. Such factors must be carefully studied before a model is chosen for a specific type of system.

The availability of data is a major consideration in determining the method to be used for critical load determination. This factor generally limits the methods to empirical methods or to steadystate and the simpler dynamic modelling approaches.

\subsubsection{Steady State Mass Balance (SSMB) Model}

The Steady State Mass Balance model is calculated manually and can be used for quick evaluation of scenarios involving relatively higher and lower levels of acid deposition and neutralizing capacities to arrive at critical loads. This is a one-layer model wherein only a specified thickness of the soil profile can be considered. Details are presented in Section 5.2.1.

Critical load determination by the SSMB model is directly dependent on the weathering rate, which is the major long-term source of alkalinity that neutralizes acidity in the soil system and the major source of base cations for replacing those removed by leaching. Thus, confidence in 
the critical load determined by this method depends on the level of confidence in the model input value for the weathering rate. Most estimations of weathering rate are based on correlations of experimentally determined weathering rates with soil type, mineralogy, base cation content or texture. Others are based on computations using soil mineralogy, wherein quantitative data for the complete suite of minerals present in a soil are required. The approach has been widely used in Europe to provide a weathering term for input into the SSMB equation (Task Force on Mapping 1996).

Another approach to estimating weathering is based on an estimation of mineralogy from total chemical analysis of soil by use of the UPPSALA model which performs a stepwise allocation of elements ( $\mathrm{Ca}, \mathrm{Mg}$ etc.) to different soil minerals. Minimal data needed by the UPPSALA model for converting elemental contents to mineralogy are levels of total $\mathrm{Na}, \mathrm{K}, \mathrm{Ca}, \mathrm{Mg}, \mathrm{P}, \mathrm{Al}, \mathrm{Si}$ and Fe (Sverdrup 1990).

The SSMB approach is applicable in Alberta in terms of the three criteria of simplicity, availability and applicability in critical load derivation. Critical loads can easily be calculated for an individual soil, or a large number of computations can be made within a spreadsheet. The SSMB model was applied to the Edmonton West study area using a weathering rate estimated from information in the literature as described in Section 5.2.2.

\subsubsection{Alberta Research Council (ARC) Model}

The ARC model is derived from Bloom and Grigal (1985) and incorporates empirical relationships for cation exchange and $\mathrm{pH}$ based on Alberta soil properties. The model has been described by Abboud and Turchenek (1990) and Turchenek and Abboud (1988), and is described in part in Section 6 of this report.

\subsection{SURFACE WATER ACIDIFICATION MODELS}

The determination of critical loads of acidity to surface waters was an initial objective in determining critical loads in the Edmonton West study area. However, the high salinity of lakes in the region results in very low acidification sensitivity. Thus, there was no concerted effort made in determining the critical loads to surface waters in this area.

\subsection{MODELS USED TO DERIVE CRITICAL LOADS FOR SOILS IN THE EDMONTON WEST STUDY AREA}

The SSMB and ARC models were previously applied to determination of critical loads in the Provost-Esther area (Turchenek and Abboud 2001) and the Edmonton East study area (Abboud and Turchenek 2008). An empirical method was also applied, in which critical loads were based on the Skokloster method. 
Information about the distribution and properties of soils in the Edmonton West study area is available from soil survey reports and from the AGRASID database (Alberta Soil Information Centre 2007). The AGRASID database provides soil survey coverage for the agricultural regions of Alberta, along with descriptions of soil series, including typical soil chemical attributes. Soil distribution is presented in the database within a hierarchical framework based on the national ecological framework for Canada (Ecological Stratification Working Group 1995).

The Edmonton West study area is within the Prairies Ecozone. An Ecozone is an area that is representative of large and very generalized ecological units characterized by interactive and adjusting abiotic and biotic factors.

An Ecoregion is a part of an Ecozone characterized by distinctive ecological responses to climate as expressed by the development of vegetation, soil, water, fauna, etc. (Ecological Stratification Working Group 1995). The study area occurs within the Aspen Parkland ecoregion, with the northern edges bordering the Boreal Transition Ecoregion. The Aspen Parkland is characterized by predominance of Black Chernozemic soils, with inclusions of Gleysolic and Solonetzic soils. These soils transition to the predominantly Luvisolic soils of the Boreal Plains ecoregion, which are associated with Brunisolic soils where materials are coarse textured. Gleysols occupy poorly drained depressions, and Organic (peat) soils occur increasingly toward the northern part of the area.

An Ecodistrict is a subdivision of an Ecoregion in the ecological land classification hierarchy. It is characterized by distinct assemblages of landform, relief, surficial geologic material, soil, water bodies, vegetation and land uses (Ecological Stratification Working Group 1995). The soil mapping system in Alberta further subdivides Ecodistricts into Land Systems. A Land System is defined as a subdivision of an Ecodistrict that is recognized and separated by differences in one or more of general pattern of land surface form, surficial geologic materials, amount of lakes or wetlands, or general soil pattern. All Land Systems within one Ecodistrict have the same general climate for agriculture, but differences in microclimatic pattern can be recognized. Soil Landscapes are subdivisions of Land Systems that display a consistent and recognizable pattern of distribution of soils and landscape elements (Alberta Soil Information Centre, 2007).

Soil types as identified at the Land System level were applied in developing a sampling protocol and critical loads map of the study area. Analysis of soil types at the Soil Landscape level of mapping would prove to be unwieldy due to the large number of delineations within one grid cell. Land Systems provide information at a lower level of detail, but at a somewhat greater level than that of the land units that form the basis of soil sensitivity mapping by Holowaychuk and Fessenden (1987). Consequently, Land System information was considered to be a practical basis for refining the previous soil sensitivity mapping and for calculating critical loads. 


\subsection{INITIAL ACID SENSITIVITY RATING}

Each Land System is characterized by an assemblage of dominant and subdominant soil series. The extent of each series was estimated from the attribute information provided in AGRASID. These were then allocated an acid sensitivity rating based on base loss, acidification, aluminum solubilization and overall sensitivity ratings using soil $\mathrm{pH}$ and cation exchange capacity as the major criteria (Holowaychuk and Fessenden 1987). The ratings were developed for the top 20 $\mathrm{cm}$ of soil. However, soil chemical data reported in soil survey reports are based on one or very few sampled profiles, and it is difficult to fully rely on these data for sensitivity classification. Of the soil attributes described in soil survey reports, texture would be considered as one that is frequently and reliably estimated in the field. Cation exchange capacity is strongly related to texture because of its dependence on the clay content of the soil. Thus, instead of applying the Holowaychuk and Fessenden (1987) sensitivity classification using chemistry data only, soils in the Edmonton West study area were assigned preliminary sensitivity ratings on the basis of texture as well. Soils of sand or loamy sand texture were characterized as being Sensitive to acid deposition. Soils of sandy loam texture were assigned a Moderate Sensitivity rating. Luvisols were mainly assigned a Moderate rating because the topsoils (A horizons) commonly have sandy loam textures, even though the underlying material is fine textured. All Chernozemic soils of texture finer than sandy loam (including fine and very fine sandy loam) were assigned a Low Sensitivity rating.

The sensitivity rating allocation to Land Systems provided information about coverage of all potentially acid sensitive soils. This provided a framework for representative sampling of soils for the critical loads evaluation. Agricultural soils and native/range soils of Low Sensitivity were excluded from the evaluation because (1) acid deposition management is to be based on the extent of sensitive soils affected (Clean Air Strategic Alliance and Alberta Environment 1999), and (2) these soils are generally under cultivation and subject to various management practices, particularly fertilization, which confound any evaluations of acidification due to atmospheric deposition. In the Edmonton West study area, native rangelands were included, although these consist mainly of soils under native forest. Open forage and range areas have generally had tree cover removed and consist of non-native species. Although these lands have been cultivated and possibly fertilized, soil samples were taken from some sites in order to examine their potential sensitivity to acid deposition.

The sensitivity ratings were re-evaluated upon completion of the critical load determinations, with allocations to sensitivity classes based on $\mathrm{pH}$, base saturation percentage and base cation to aluminum ratio. These were compared with the criteria of Holowaychuk and Fessenden (1987), and a revised soil distribution and acid sensitivity map was produced for the study area.

\section{3}

\section{LAND USE INFORMATION}

As indicated previously, forage and crop lands are subjected to various practices such as fertilization and manure application, and these would complicate evaluations in relation to atmospheric acid deposition. Additionally, soils under cultivation are generally soils that have higher nutrient content and buffering capacity (base cations), and are therefore the least sensitive soils within any given area. In addition to land use information, soil and landscape 
information was therefore required to enable planning of a sampling program, and more importantly, to enable calculation of the areal extents of soils of different acid sensitivity.

Land use information was obtained from the Prairie Farm Rehabilitation Administration (PFRA 2001) which had undertaken mapping for the purpose of verifying applications under the Western Grain Transition Payments Program (WGTPP). The WGTPP map was based on analysis of satellite images acquired from 1993 to 1995, and land cover was allocated to one of eleven classes:

1. Cultivated crop land - land that is annually seeded or under summer fallow;

2. Forage (hay) - land that is in perennial forage for hay or silage production (dominantly alfalfa);

3. Grasslands - land that is in perennial grasses and herbaceous species for grazing use including native range, seeded tame pasture, abandoned farm areas and other noncultivated uses (ditches, riparian areas, etc.);

4. Shrubs - land that has perennial woody shrub coverage;

5. Trees - hardwoods, mixed woods, recent burns and cutovers;

6. Wetlands - intermittent water bodies, area that have semi-permanent or permanent wetland vegetation, including fens, bogs, swamps, sloughs, marshes, etc.;

7. Water - permanent water bodies including lakes, rivers, irrigation canals;

8. Non-agricultural lands - land that is dominantly in a non-vegetative or non-agricultural land use, including farmsteads, roads, cities, towns, open pit mines, industrial sites, etc.;

9. Clouds and shadow;

10. Mud, sand and/or saline areas; and,

11. Unclassified area - areas outside of the study area.

Areas classed as Shrubs or Trees (categories 4 and 5 above) were selected from the WGTPP digital database and superimposed on the initial soil and soil sensitivity map, the development of which is described in Section 3.2 above. All other land was regarded as tilled land, although minor areas of disturbed lands (in addition to urban areas) occurred as well. Spatial information about water bodies was then taken from a separate digital layer in the database to produce a combined soil/land use/surface water map.

There can be uncertainty in the classification of certain types of land in the PFRA land classification. Moreover; the imagery that the classification was based on is now dated. This is nevertheless the most readily available land cover database. An inherent assumption in the sensitivity analysis herein is that this land cover information is more or less accurate, and that it is adequate for deriving statistics for areas of soils with different sensitivity ratings.

\subsection{BASELINE SURFACE WATER INFORMATION}

Information about the distribution and extent of surface water bodies in the Edmonton West study area was derived from the WGTPP information as indicated in Section 3.3. Detailed information about the areas of wetlands within the ecosystems of Alberta is available in 'Ecodistricts of Alberta: Summary of Biophysical Attributes' (Strong and Thompson 1995) and in 'Characterization of Wetlands in the Settled Area of Alberta' (Strong et al. 1993). Information about shallow water bodies is included in the latter compilation, but lakes are not included. 
Water quality information is available in the form of a digital database maintained by Alberta Environment. The database presents values for $\mathrm{pH}$, alkalinity, total dissolved solids and calcium for more than 1,000 Alberta Lakes, with information about additional lakes added on an ongoing basis (Saffran and Trew 1996).

\section{$3.5 \quad$ SOIL SAMPLING}

The goals established for soil sampling to meet the needs of critical load determination were to obtain soil samples of the LFH and the top $25 \mathrm{~cm}$ of mineral topsoil at a minimum of 25 sites from the Sensitive and Moderate acidification sensitivity areas in the study region.

The initial soil and soil sensitivity rating (Section 3.2) resulted in identification of 12 Land Systems that have a component of potentially Sensitive or 'Sensitive plus Moderate' soils, and one additional Land System in which soils of potential Moderate Sensitivity to acidic deposition occur. These areas varied in size. Sampling within the Edmonton region was logistically challenging in terms of obtaining permission to enter lands, and finding suitable areas for sampling within relatively densely populated areas such as acreage developments. Consequently, locations categorized as natural areas, parks and other crown lands were targeted for collection of samples. Some sites outside the boundaries of the study area were selected, provided they were located within land systems that extended into the Edmonton West study area.

Soil samples were taken by excavating a small pit to at least $50 \mathrm{~cm}$ depth and taking about a volume of about $2 \mathrm{~L}$ of both LFH (forest floor) and 0-25 cm horizons. In most instances, the 0-25 sampling layer occurred entirely within the A horizon. In some case where the A horizon was thinner than $25 \mathrm{~cm}$, a portion of the B horizon to the $25 \mathrm{~cm}$ depth was included in the sample. The samples were collected in October and early November, 2005.

\subsection{WATER SAMPLING}

Water samples were collected from two water bodies that were of significant size but not included in the provincial water quality database. It was found, however, that most lakes in the study area appeared to be very shallow, or had dried out, and all were generally characterized by saline margins. The samples were taken from Longhurst Lake, located in NE36-51-1-W5 (just outside grid cell, on the 5th Meridian), and an unnamed lake located in NW33-51-27-W4. One $500 \mathrm{~mL}$ sample was collected, and $\mathrm{pH}$ was determined within two hours with a portable $\mathrm{pH}$ meter. Samples were collected from the lake shore using a pole of about 4 metres length, with the sample bottle attached to the end of the pole.

\subsection{SOIL ANALYSES}

Soil samples were analyzed for various properties as follows:

$\mathrm{pH}\left(\mathrm{CaCl}_{2}\right.$ ): By potentiometric measurement using $0.01 \mathrm{M} \mathrm{CaCl}_{2}$ in a $1: 2$ (w:v) solid-to-liquid mixture (Method 7 (ii) in Kalra and Maynard (1991). The soil-to-solution ratio for litter (LFH) material was 1:4.

Cation Exchange Capacity (Buffered): By 1.0 M ammonium acetate extractant buffered at pH $\gamma$. and measurement of $\mathrm{NH}_{4}{ }^{+}$by distillation. The method was applied as described in Procedure 
3.3.2 in McKeague (1978), except that $\mathrm{NH}_{4}{ }^{+}$was not displaced with $\mathrm{Na}$, and the whole sample was distilled to determine the content of adsorbed $\mathrm{NH}_{4}^{+}$.

Exchangeable Ions: By Inductively Coupled Plasma (ICP) Atomic Emission Spectroscopy of the unbuffered CEC extract. Ions included in the ICP scan were $\mathrm{Ca}, \mathrm{Mg}, \mathrm{Na}, \mathrm{K}, \mathrm{Fe}, \mathrm{Mn}$ and $\mathrm{Al}$.

Electrical Conductivity and Soluble Salts: By measurement of electrical conductivity and ions in the aqueous extract from a saturated paste of a soil sample (Method 8(i), Kalra and Maynard (1991). EC and pH were measured in the extract. A portion of the extract was filtered using a $0.45-\mu \mathrm{m}$ micropore filter, and a full ICP elemental scan, including $S$ and $A$, was conducted on the extract.

\subsection{METEOROLOGICAL DATA}

Precipitation data were obtained from the website of the Atmospheric Environment Service (Environment Canada 2006), for the years 1990 - 2000. This was supplemented by data from Canadian Climate Normals 1961 - 1990 (Environment Canada 1993). Data were obtained for the meteorological station at the Edmonton International Airport.

\subsection{PRECIPITATION SURPLUS}

Some models use the term 'precipitation minus potential evapotranspiration' to obtain an approximation of the amount of deep percolation of soil moisture, or to approximate total precipitation surplus including runoff. Potential evapotranspiration exceeds precipitation in the study area, however, the depth of soil profile development suggests that water penetrates to about 0.8 metres in sandy soils in the study area. A soil depth of $25 \mathrm{~cm}$ was applied in determining acidification with models, this being the depth within which the majority of plant roots occur. Therefore, the amount of water percolating beyond the surface $25 \mathrm{~cm}$ zone was calculated.

Daily precipitation data for the months of April to October, inclusive, were obtained for the years 1990 to 1995 . The amounts of precipitation retained by the soil on a daily basis was estimated by assuming a field capacity of $16.7 \mathrm{~mm}$ per $25 \mathrm{~cm}$, this being based on an available water content of $80 \mathrm{~mm}$ per 1.2 metres for sandy soils (Tajek et al. 1989). The daily evapotranspiration rates were subtracted from this amount. Actual monthly evapotranspiration rates were obtained from Bothe and Abraham (1993). These rates were as follows: April, $2 \mathrm{~mm}$ $\mathrm{d}^{-1}$; May, $4 \mathrm{~mm} \mathrm{~d}^{-1}$; June, $6 \mathrm{~mm} \mathrm{~d}^{-1}$; July, $7 \mathrm{~mm} \mathrm{~d}^{-1}$; August, $6 \mathrm{~mm} \mathrm{~d}^{-1}$; September, $4 \mathrm{~mm} \mathrm{~d}^{-1}$; and, October, $2 \mathrm{~mm} \mathrm{~d}^{-1}$. All winter snowfall was assumed to percolate into the soil, and evapotranspiration was assumed to be zero for this period.

The difference between the precipitation and the precipitation surplus represents the proportion of the precipitation that reacts with the upper $25 \mathrm{~cm}$ soil layer. Another implication of the precipitation surplus concept is that the products of any reactions within the top $25 \mathrm{~cm}$ of the soil are carried down the profile; that is, base cations may be lost from the upper layer.

While most roots are assumed to occur in the top $25 \mathrm{~cm}$, a proportion occurs at some depth in the profile and takes up nutrients as well as water. Thus, it is possible that upward movement of nutrients through deep roots would add nutrients to the upper soil layers, which would serve to 
counteract the effects of acidification on plants. However, it is difficult to estimate the amount of upward nutrient transport by deep roots. It was considered that this is a minor process within the ecosystem, and therefore, this amount was not estimated and it was assumed for modelling purposes that no nutrient return occurs by this mechanism.

\subsection{ACID DEPOSITION DATA}

Acid deposition data were obtained from province-wide estimates of deposition by Cheng et al. (1997). For the ARC model, the Potential Acid Input (PAI) was applied. The PAI reported by Cheng et al. (1997) for the Edmonton West map sheet was 0.15 to $0.20 \mathrm{kmol} \mathrm{H}^{+} \mathrm{ha}^{-1} \mathrm{yr}^{-1}$, and more recently the estimate was 0.17 to $0.22 \mathrm{kmol} \mathrm{H}^{+} \mathrm{ha}^{-1} \mathrm{yr}^{-1}$ (WBK \& Associates Inc., 2006). The upper number in this range $\left(0.20 \mathrm{kmol} \mathrm{H}^{+} \mathrm{ha}^{-1} \mathrm{yr}^{-1}\right)$ was applied in models. This rate is equivalent to $0.3 \mathrm{kmol} \mathrm{H}^{+} \mathrm{ha}^{-1} \mathrm{yr}^{-1}$ of $\mathrm{SO}_{x}, \mathrm{NO}_{\mathrm{x}}$ and $\mathrm{NH}_{\mathrm{x}}$ deposition, partially neutralized by 0.1 $\mathrm{kmol} \mathrm{H}^{+} \mathrm{ha}^{-1} \mathrm{yr}^{-1}$ of base cation deposition.

\subsection{OTHER DATA REQUIREMENTS}

Other model data inputs consisting of constants, coefficients, soil analytical data or soil parameters obtained from the literature, or they have been derived for Alberta soils (see Section $5)$.

\subsection{MAP COMPILATION}

A soil map of the Edmonton West study area was developed from the AGRASID soils database and PFRA land cover databases as described in Sections 3.1 to 3.3. Only information at the Land System level was used, as this was considered to be an appropriate level of detail for generalized depiction of the distribution of soil types and their sensitivity to acid deposition. Additionally, it provided a suitable level of stratification for planning a soil sampling program.

Digital files for base map information as well as land use data were obtained from the PFRAWGTPP data base (PFRA 2001). The base map files were registered to UTM Zone 12, NAD '83 coordinates. This coordinate system was maintained throughout all digital processing and formed the basis for geographic referencing of the final map products.

Delineations of Land Systems from the AGRASID database were linked to the base information using $A R C / V I E W^{\odot}$. The data were exported to $A R C / I N F O^{\odot}$ for topological construction, attribute linkage and map product output, the latter including incorporation of a soil sensitivity legend. 


\subsection{ECOLOGICAL STRATIFICATION}

The most detailed level of mapping in the AGRASID database is the Soil Landscape unit. A Soil Landscape is a subdivision of a Land System that displays a consistent and recognizable pattern of distribution of soils and landscape elements (Alberta Soil Information Centre 2007). As indicated in Section 3.12, the Soil Landscape mapping unit was considered to be too detailed for application in this project, and the Land System was applied instead.

A map of Land Systems in the study area is presented in the back pocket of this report. A legend describes characteristics of the Land Systems in terms of parent geologic materials, landscapes and soil types. The Land Systems are also described in Table 2.

\subsection{SOIL CLASSIFICATION}

The study area occurs within the Aspen Parkland ecoregion, with the northern edges bordering the Boreal Transition Ecoregion. The Aspen Parkland is characterized by predominance of Black Chernozemic soils, with inclusions of Gleysolic and Solonetzic soils. These soils transition to the predominantly Luvisolic soils of the Boreal Plains ecoregion, which are associated with Brunisolic soils where materials are coarse textured. Gleysols occupy poorly drained depressions, and Organic (peat) soils occur increasingly toward the northern part of the area.

Individual soil types within Soil Landscapes are identified at the Soil Series level of the Canadian System of Soil Classification (Soil Classification Working Group 1998). A soil series is a category (or level) in the Canadian system of soil classification. It is the basic unit of soil classification, and consists of soils that are essentially alike in all major profile characteristics except the surface texture. Naming of Soil Series is based on the Alberta Soils Names File (Generation 3) User's Handbook and Soil Correlation Area (SCA) Map of Alberta (2006) (Alberta Soil Information Centre 2007). Soil series within the study area are listed in Table 3. 
Table 2. Description of the Land Systems in the Edmonton West Study Area

\begin{tabular}{|c|c|c|c|c|c|}
\hline $\begin{array}{l}\text { LAND } \\
\text { SYSTEM } \\
\text { SYMBOL }^{Z}\end{array}$ & $\begin{array}{l}\text { LAND } \\
\text { SYSTEM } \\
\text { NAME }\end{array}$ & LAND SYSTEM DESCRIPTION & $\begin{array}{l}\text { SOIL } \\
\text { ZONE }\end{array}$ & $\begin{array}{l}\text { MAJOR } \\
\text { SOILS }\end{array}$ & $\begin{array}{l}\text { MINOR } \\
\text { SOILS }\end{array}$ \\
\hline 05.00 .09 & $\begin{array}{l}\text { Battle River } \\
\text { Valley }\end{array}$ & \begin{tabular}{|l|} 
Landscape is valley bottom with some confined \\
floodplain. Regosols developed on undifferentiated \\
material. Minor soils include coarse textured soils. \\
Significant eroded soils present.
\end{tabular} & Thin Black & ZER & MKR-AA \\
\hline 05.3d.01 & Morinville Plain & \begin{tabular}{|l|} 
Landscape is undulating. Black Solonetz \\
developed on medium textured till and fine \\
textured water-laid sediments. Minor soils include \\
Chernozems and Gleysols.
\end{tabular} & $\begin{array}{l}\text { Black-Dark } \\
\text { Gray }\end{array}$ & $\begin{array}{l}\text { CMO } \\
\text { DUG }\end{array}$ & $\begin{array}{l}\text { AGS } \\
\text { ZGW }\end{array}$ \\
\hline $05.3 \mathrm{~d} .07$ & Namao Plain & $\begin{array}{l}\text { Landscape is undulating. Black Chernozems } \\
\text { developed on fine textured water-laid sediments } \\
\text { and medium textured water-laid sediments. }\end{array}$ & $\begin{array}{l}\text { Black-Dark } \\
\text { Gray }\end{array}$ & $\begin{array}{l}\text { MMO } \\
\text { POK }\end{array}$ & $\begin{array}{l}\text { AGS } \\
\text { MCO }\end{array}$ \\
\hline $05.3 \mathrm{~d} .09$ & Partridge Plain & $\begin{array}{l}\text { Landscape is undulating. Black Chernozems } \\
\text { developed on medium textured till. Minor soils } \\
\text { include Gleysols. }\end{array}$ & $\begin{array}{l}\text { Black-Dark } \\
\text { Gray }\end{array}$ & AGS & $\begin{array}{l}\text { RLV } \\
\text { ZGL }\end{array}$ \\
\hline 05.3d.10 & Cawes Plain & $\begin{array}{l}\text { Landscape is undulating. Black Chernozems } \\
\text { developed on medium textured till. }\end{array}$ & $\begin{array}{c}\text { Black-Dark } \\
\text { Gray }\end{array}$ & AGS & $\begin{array}{l}\text { HBM } \\
\text { RLV }\end{array}$ \\
\hline $05.3 d .11$ & $\begin{array}{l}\text { Pointe-aux- } \\
\text { Pins Plain } \\
\end{array}$ & $\begin{array}{l}\text { Landscape is undulating. Black Chernozems } \\
\text { developed on fine textured water-laid sediments. }\end{array}$ & $\begin{array}{c}\text { Black-Dark } \\
\text { Gray }\end{array}$ & MMO & $\begin{array}{l}\text { AGS } \\
\text { LOM }\end{array}$ \\
\hline 05.3d.14 & $\begin{array}{c}\text { City of } \\
\text { Edmonton }\end{array}$ & City of Edmonton. & $\begin{array}{l}\text { Black-Dark } \\
\text { Gray }\end{array}$ & ZDL & \\
\hline $05.3 d .18$ & $\begin{array}{c}\text { Spruce Grove } \\
\text { Plain }\end{array}$ & $\begin{array}{l}\text { Landscape is undulating with some peatlands. } \\
\text { Dark Gray Chernozems developed on medium } \\
\text { textured water-laid sediments. Minor soils include } \\
\text { Organic and fine textured soils. }\end{array}$ & $\begin{array}{l}\text { Black-Dark } \\
\text { Gray }\end{array}$ & WTB & $\begin{array}{l}\text { ZOR } \\
\text { MMO }\end{array}$ \\
\hline 05.3d.19 & $\begin{array}{l}\text { Longhurst } \\
\text { Plain }\end{array}$ & $\begin{array}{l}\text { Landscape is undulating with some peatlands. } \\
\text { Dark Gray Chernozems developed on medium } \\
\text { textured water-laid sediments. Minor soils include } \\
\text { Organic and coarse textured soils. }\end{array}$ & $\begin{array}{l}\text { Black-Dark } \\
\text { Gray }\end{array}$ & WTB & $\begin{array}{l}\text { RDW } \\
\text { ZOR }\end{array}$ \\
\hline $05.3 d .20$ & Graminia Plain & $\begin{array}{l}\text { Landscape is undulating with some duned. Dark } \\
\text { Gray Luvisols developed on coarse textured } \\
\text { sediments. Minor soils include Organic. }\end{array}$ & $\begin{array}{c}\text { Black-Dark } \\
\text { Gray }\end{array}$ & $\begin{array}{l}\text { ELP } \\
\text { TGL }\end{array}$ & ZOR \\
\hline $05.3 d .21$ & Calmar Plain & $\begin{array}{l}\text { Landscape is undulating. Black Chernozems } \\
\text { developed on fine textured water-laid sediments. }\end{array}$ & $\begin{array}{c}\text { Black-Dark } \\
\text { Gray }\end{array}$ & MMO & $\begin{array}{l}\text { POK } \\
\text { LOM }\end{array}$ \\
\hline $05.3 d .22$ & Watelet Plain & $\begin{array}{l}\text { Landscape is undulating. Black Chernozems and } \\
\text { Black Solonetz developed on medium textured till } \\
\text { and medium textured softrock. }\end{array}$ & $\begin{array}{l}\text { Black-Dark } \\
\text { Gray }\end{array}$ & $\begin{array}{l}\text { AGS } \\
\text { KVG }\end{array}$ & $\begin{array}{l}\text { HBM } \\
\text { RLV }\end{array}$ \\
\hline $05.3 d .26$ & Big Hay Plain & $\begin{array}{l}\text { Landscape is undulating with some level, closed } \\
\text { basin. Black Chernozems and Black Solonetz } \\
\text { developed on medium textured till and fine } \\
\text { textured water-laid sediments. Minor soils include } \\
\text { Gleysols. }\end{array}$ & $\begin{array}{l}\text { Black-Dark } \\
\text { Gray }\end{array}$ & $\begin{array}{l}\text { AGS } \\
\text { WKN }\end{array}$ & $\begin{array}{l}\text { MMO } \\
\text { ZGW }\end{array}$ \\
\hline $05.3 d .27$ & Ferlow Plain & $\begin{array}{l}\text { Landscape is hummocky. Black Chernozems } \\
\text { developed on medium textured till. Minor soils } \\
\text { include Gleysols. }\end{array}$ & $\begin{array}{l}\text { Black-Dark } \\
\text { Gray }\end{array}$ & AGS & $\begin{array}{l}\text { RLV } \\
\text { ZGW }\end{array}$ \\
\hline $05.3 d .28$ & $\begin{array}{l}\text { Pipestone } \\
\text { Upland }\end{array}$ & $\begin{array}{l}\text { Landscape is undulating with some duned. Black } \\
\text { Chernozems developed on coarse textured } \\
\text { sediments and medium textured water-laid } \\
\text { sediments. Minor soils include Gleysols. }\end{array}$ & $\begin{array}{l}\text { Black-Dark } \\
\text { Gray }\end{array}$ & $\begin{array}{l}\text { PHS } \\
\text { POK }\end{array}$ & ZGW \\
\hline $05.3 d .30$ & Bigstone Plain & $\begin{array}{l}\text { Landscape is undulating with some duned. Black } \\
\text { Chernozems developed on coarse textured } \\
\text { sediments and medium textured material over } \\
\text { medium textured till. Minor soils include Gleysols. }\end{array}$ & $\begin{array}{l}\text { Black-Dark } \\
\text { Gray }\end{array}$ & $\begin{array}{l}\text { PHS } \\
\text { HBM }\end{array}$ & $\begin{array}{l}\text { POK } \\
\text { ZGW }\end{array}$ \\
\hline
\end{tabular}


Table 2. Description of the Land Systems in the Edmonton West Study Area

\begin{tabular}{|c|c|c|c|c|c|}
\hline $\begin{array}{l}\text { LAND } \\
\text { SYSTEM } \\
\text { SYMBOL }^{\mathrm{Z}}\end{array}$ & $\begin{array}{l}\text { LAND } \\
\text { SYSTEM } \\
\text { NAME }\end{array}$ & LAND SYSTEM DESCRIPTION & $\begin{array}{l}\text { SOIL } \\
\text { ZONE }\end{array}$ & $\begin{array}{l}\text { MAJOR } \\
\text { SOILS }\end{array}$ & $\begin{array}{l}\text { MINOR } \\
\text { SOILS }\end{array}$ \\
\hline $05.3 d .31$ & $\begin{array}{l}\text { Samson Lake } \\
\text { Plain }\end{array}$ & $\begin{array}{l}\text { Landscape is undulating. Black Chernozems } \\
\text { developed on fine textured water-laid sediments. } \\
\text { Minor soils include Solonetz and Gleysols. }\end{array}$ & $\begin{array}{l}\text { Black-Dark } \\
\text { Gray }\end{array}$ & MMO & $\begin{array}{l}\text { WKN } \\
\text { ZGW }\end{array}$ \\
\hline $05.3 \mathrm{~d} .50$ & Looma Upland & $\begin{array}{l}\text { Landscape is hummocky. Dark Gray Chernozems } \\
\text { and Dark Gray Luvisols developed on medium } \\
\text { textured till. Minor soils include Gleysols and fine } \\
\text { textured soils. }\end{array}$ & $\begin{array}{l}\text { Black-Dark } \\
\text { Gray }\end{array}$ & $\begin{array}{l}\text { RLV } \\
\text { UCS }\end{array}$ & $\begin{array}{l}\text { MCO } \\
\text { ZGW }\end{array}$ \\
\hline $05.4 a .15$ & Ryley Plain & $\begin{array}{l}\text { Landscape is undulating. Black Solonetz } \\
\text { developed on medium textured till. Minor soils } \\
\text { include Chernozems and Gleysols. }\end{array}$ & $\begin{array}{l}\text { Black-Dark } \\
\text { Gray }\end{array}$ & $\mathrm{CMO}$ & $\begin{array}{l}\text { NRM } \\
\text { ZGW }\end{array}$ \\
\hline 05.6 .01 & Islet Upland & $\begin{array}{l}\text { Landscape is hummocky. Dark Gray and Dark Gray } \\
\text { Luvisols developed on medium textured till. Minor soils } \\
\text { include Gleysols, Chernozems and fine textured soils. }\end{array}$ & $\begin{array}{l}\text { COA } \\
\text { UCS }\end{array}$ & $\begin{array}{l}\text { ZGW } \\
\text { MCO }\end{array}$ & $\begin{array}{l}\mathrm{H} 1 \mathrm{~m} \\
\mathrm{H} 11\end{array}$ \\
\hline 06.00 .03 & \begin{tabular}{|c|} 
North \\
Saskatchewan \\
River Valley
\end{tabular} & $\begin{array}{l}\text { Landscape is inclined }<10 \% \text { exposed bedrock with } \\
\text { some numerous water bodies and undulating. }\end{array}$ & $\begin{array}{c}\text { Black-Dark } \\
\text { Gray }\end{array}$ & ZER & \\
\hline $06.1 \mathrm{~b} .02$ & Yeoford Plain & $\begin{array}{l}\text { Landscape is undulating with some rolling and } \\
\text { hummocky. Dark Gray and Gray Luvisols } \\
\text { developed on medium textured till. Minor soils } \\
\text { include Chernozems. }\end{array}$ & $\begin{array}{c}\text { Black-Dark } \\
\text { Gray }\end{array}$ & $\begin{array}{l}\text { BEN } \\
\text { BTN }\end{array}$ & $\begin{array}{l}\text { FLU } \\
\text { KHS }\end{array}$ \\
\hline $06.1 \mathrm{~b} .03$ & Pigeon Lake & Large water body. & $\begin{array}{c}\text { Black-Dark } \\
\text { Gray }\end{array}$ & N/A & N/A \\
\hline $06.1 c .12$ & Falun Plain & $\begin{array}{l}\text { Landscape is undulating. Dark Gray Luvisols and } \\
\text { Dark Gray Chernozems developed on medium } \\
\text { textured till. Minor soils include Organic. }\end{array}$ & $\begin{array}{c}\text { Black-Dark } \\
\text { Gray }\end{array}$ & $\begin{array}{l}\text { BEN } \\
\text { FLU }\end{array}$ & $\begin{array}{l}\text { BTN } \\
\text { ZOR }\end{array}$ \\
\hline $06.1 \mathrm{~d} .02$ & $\begin{array}{l}\text { George Lake } \\
\text { Plain }\end{array}$ & $\begin{array}{l}\text { Landscape is hummocky with some numerous } \\
\text { water bodies. Gray Luvisols and Gray Solonetz } \\
\text { developed on medium textured till. Minor soils } \\
\text { include Gleysols. }\end{array}$ & $\begin{array}{c}\text { Black-Dark } \\
\text { Gray }\end{array}$ & $\begin{array}{l}\text { COA } \\
\text { DNT }\end{array}$ & $\begin{array}{l}\text { NKU } \\
\text { ZGW }\end{array}$ \\
\hline $06.1 \mathrm{~d} .08$ & $\begin{array}{l}\text { Onoway } \\
\text { Upland }\end{array}$ & $\begin{array}{l}\text { Landscape is hummocky. Gray and Dark Gray } \\
\text { Luvisols developed on medium textured till. Minor } \\
\text { soils include Organic and Chernozems. }\end{array}$ & $\begin{array}{c}\text { Black-Dark } \\
\text { Gray }\end{array}$ & $\begin{array}{l}\text { COA } \\
\text { UCS }\end{array}$ & $\begin{array}{l}\text { ZOR } \\
\text { ZCO }\end{array}$ \\
\hline $06.1 \mathrm{~d} .20$ & $\begin{array}{l}\text { Mink Lake } \\
\text { Plain }\end{array}$ & $\begin{array}{l}\text { Landscape is hummocky. Gray Luvisols developed } \\
\text { on medium textured water-laid sediments. }\end{array}$ & $\begin{array}{c}\text { Black-Dark } \\
\text { Gray }\end{array}$ & $\begin{array}{l}\text { GOY } \\
\text { HGV }\end{array}$ & $\begin{array}{l}\text { CVL } \\
\text { KHS }\end{array}$ \\
\hline $06.1 \mathrm{~d} .21$ & $\begin{array}{c}\text { Pemburton Hill } \\
\text { Plain }\end{array}$ & $\begin{array}{l}\text { Landscape is undulating. Dark Gray Luvisols } \\
\text { developed on very fine textured water-laid } \\
\text { sediments and areas of moderately fine textured } \\
\text { till. Minor soils include Gleysols. } \\
\end{array}$ & & MLA & $\begin{array}{l}\text { BOB } \\
\text { ZGW }\end{array}$ \\
\hline $06.2 a .05$ & $\begin{array}{l}\text { Redwater } \\
\text { Plain }\end{array}$ & $\begin{array}{l}\text { Landscape is undulating with some duned. Black } \\
\text { Chernozems developed on coarse textured } \\
\text { sediments. Minor soils include Brunisols. }\end{array}$ & $\begin{array}{c}\text { Black-Dark } \\
\text { Gray }\end{array}$ & MDR & $\begin{array}{l}\text { PRM } \\
\text { PHS }\end{array}$ \\
\hline $06.2 a .09$ & $\begin{array}{l}\text { Halfway Lake } \\
\text { Dunefield }\end{array}$ & $\begin{array}{l}\text { Landscape is undulating and duned. Brunisols and } \\
\text { Dark Gray Chernozems developed on coarse } \\
\text { textured sediments. Minor soils include Organic } \\
\text { and Gleysols. }\end{array}$ & $\begin{array}{c}\text { Black-Dark } \\
\text { Gray }\end{array}$ & $\begin{array}{l}\text { PRM } \\
\text { HLW }\end{array}$ & $\begin{array}{l}\text { ZOR } \\
\text { ZGW }\end{array}$ \\
\hline $06.2 \mathrm{a} .11$ & Eldorena Plain & $\begin{array}{l}\text { Landscape is undulating with some duned. Black } \\
\text { Chernozems and Brunisols developed on coarse } \\
\text { textured sediments. }\end{array}$ & $\begin{array}{c}\text { Black-Dark } \\
\text { Gray }\end{array}$ & $\begin{array}{l}\text { PHS } \\
\text { PRM }\end{array}$ & $\begin{array}{l}\text { MNT-AA } \\
\text { MDR }\end{array}$ \\
\hline $06.2 b .17$ & Pakan Plain & $\begin{array}{l}\text { Landscape is undulating. Black Chernozems } \\
\text { developed on medium textured water-laid } \\
\text { sediments. Minor soils include Solonetz. }\end{array}$ & $\begin{array}{c}\text { Black-Dark } \\
\text { Gray }\end{array}$ & POK & $\begin{array}{l}\text { HBM } \\
\text { KVG }\end{array}$ \\
\hline $06.2 c .25$ & Thorhild Plain & $\begin{array}{l}\text { Landscape is undulating. Dark Gray Luvisols and } \\
\text { Dark Gray Chernozems developed on medium } \\
\text { textured till. Minor soils include Gleysols. }\end{array}$ & $\begin{array}{c}\text { Dark Gray- } \\
\text { Gray }\end{array}$ & $\begin{array}{l}\text { SDN } \\
\text { KHW }\end{array}$ & $\begin{array}{l}\text { LCY } \\
\text { ZGW }\end{array}$ \\
\hline
\end{tabular}

Z Land System identifier in AGRASID. 
Table 3. Soil Series in the Edmonton West Map Sheet

\begin{tabular}{|c|c|c|c|c|c|c|c|c|c|}
\hline Symbol & Series & Drainage & Calcar & Salinity & $\begin{array}{c}\text { PM1 } \\
\text { Texture }\end{array}$ & $\begin{array}{l}\text { PM1 } \\
\text { Type }\end{array}$ & $\begin{array}{c}\text { PM2 } \\
\text { Texture }\end{array}$ & $\begin{array}{l}\text { PM2 } \\
\text { Type }\end{array}$ & $\begin{array}{c}\text { Soil } \\
\text { Subgroup }\end{array}$ \\
\hline AGS & Angus Ridge & $W$ & $\mathrm{M}$ & $\mathrm{N}$ & MF & TILL & - & - & E.BL \\
\hline BEN & Benalto & W & W & $\mathrm{N}$ & MF & TILL & - & - & D.GL \\
\hline $\mathrm{BOB}$ & Boscombe & 1 & $M$ & $\mathrm{~N}$ & MF & TILL & - & - & GLD.GL \\
\hline BTN & Breton & W & W & $\mathrm{N}$ & MF & TILL & - & - & O.GL \\
\hline $\mathrm{CMO}$ & Camrose & W & $\mathrm{M}$ & $\mathrm{M}$ & MF & TILL & - & - & BL.SS \\
\hline CVL & Carvel & W & $\mathrm{N}$ & $\mathrm{N}$ & $\mathrm{ME}$ & GLFL & - & - & D.GL \\
\hline $\mathrm{COA}$ & Cooking Lake & W & $M$ & $\mathrm{~N}$ & MF & TILL & - & - & O.GL \\
\hline DUG & Duagh & MW & W & $M$ & $\mathrm{FI}$ & GLLC & - & - & BL.SZ \\
\hline DNT & Dnister & W & $\mathrm{M}$ & $\mathrm{M}$ & MF & TILL & - & - & G.SS \\
\hline ELP & Elk Point & W & W & $\mathrm{N}$ & $\mathrm{MC}$ & GLFL & - & - & D.GL \\
\hline FLU & Falun & $W$ & W & $\mathrm{N}$ & MF & TILL & - & - & O.DG \\
\hline GOY & Glory & W & $\mathrm{N}$ & $\mathrm{N}$ & ME & GLFL & - & - & O.GL \\
\hline HLW & Helliwell & W & W & $\mathrm{N}$ & $\mathrm{VC}$ & GLFL & - & - & O.DG \\
\hline HGV & Highvale & $W$ & $W$ & $\mathrm{~N}$ & MF & GLLC & - & - & O.GL \\
\hline HBM & Hobbema & W & $\mathrm{M}$ & $\mathrm{N}$ & $\mathrm{ME}$ & GLLC & MF & TILL & E.BL \\
\hline KVG & Kavanagh & MW & W & W & MF & SRFS & - & - & BL.SS \\
\hline KHS & Keephills & W & W & $\mathrm{N}$ & MF & GLLC & - & - & D.GL \\
\hline KHW & Kehiwin & W & $\mathrm{M}$ & $\mathrm{N}$ & MF & TILL & - & - & D.GL \\
\hline LCY & La Corey & W & $\mathrm{M}$ & $\mathrm{N}$ & MF & TILL & - & - & O.GL \\
\hline LOM & Looma & W & W & $\mathrm{N}$ & VF & GLLC & MF & TILL & O.DG \\
\hline MLA & Macola & MW & $M$ & $\mathrm{~N}$ & VF & GLLC & - & - & D.GL \\
\hline MMO & Malmo & $W$ & $W$ & $\mathrm{~N}$ & $\mathrm{FI}$ & GLLC & - & - & E.BL \\
\hline MCO & Mico & $\mathrm{MW}$ & $M$ & $\mathrm{~N}$ & VF & GLLC & - & - & O.DG \\
\hline MKR & Milk River-aa & W & $M$ & $\mathrm{~N}$ & MC & FLUV & - & - & CU.R \\
\hline NTW & Nestow & $\mathrm{R}$ & $W$ & $\mathrm{~N}$ & VC & GLFL & - & - & E.DYB \\
\hline ZDL & Disturbed Lands & - & - & - & - & - & - & - & - \\
\hline ZER & Misc. Eroded & $w$ & - & - & - & UNDM & - & - & - \\
\hline ZGW & Misc. Gleysol & $\mathrm{P}$ & - & - & - & UNDM & - & - & O.HG \\
\hline ZOR & Misc. Organic & VP & - & - & - & UNDO & - & - & TY.M \\
\hline $\mathrm{ZCO}$ & Misc. Coarse Textured & W & - & - & - & UNDM & - & - & O.BL \\
\hline ZWA & Misc. Water & VP & - & - & - & - & - & - &.-- \\
\hline MDR & Mundare & W & W & $\mathrm{N}$ & VC & GLFL & - & - & O.BL \\
\hline NKU & Nakamun & W & $M$ & W & $\mathrm{MF}$ & TILL & - & - & SZ.GL \\
\hline NRM & Norma & $W$ & $\mathrm{M}$ & $\mathrm{N}$ & MF & TILL & - & - & SZ.BL \\
\hline PHS & Peace Hills & $W$ & $W$ & $\mathrm{~N}$ & $\mathrm{MC}$ & GLFL & - & - & $\mathrm{O} . \mathrm{BL}$ \\
\hline POK & Ponoka & $W$ & $\mathrm{M}$ & $\mathrm{N}$ & $\mathrm{ME}$ & GLLC & - & - & E.BL \\
\hline PRM & Primula & $\mathrm{R}$ & $\mathrm{N}$ & $\mathrm{N}$ & VC & GLFL & - & - & E.EB \\
\hline RDW & Redwater & $w$ & $W$ & $\mathrm{~N}$ & $M C$ & GLFL & - & - & O.DG \\
\hline RLV & Rolly View & W & $M$ & $\mathrm{~N}$ & $\mathrm{MF}$ & TILL & - & - & O.DG \\
\hline SDN & Spedden & W & $M$ & $\mathrm{~N}$ & MF & TILL & - & - & O.DG \\
\hline TGL & Tigerlily & W & $M$ & $\mathrm{~N}$ & MC & GLFL & - & - & $0 . G L$ \\
\hline UCS & Uncas & W & $M$ & $\mathrm{~N}$ & MF & TILL & - & - & D.GL \\
\hline WKN & Wetaskiwin & MW & W & $M$ & $\mathrm{FI}$ & GLLC & - & - & BL.SS \\
\hline WTB & Winterburn & W & W & $\mathrm{N}$ & ME & GLFL & - & - & O.DG \\
\hline
\end{tabular}

Source: AGRASID 3.0. Alberta Soil Information Centre (2007): http://www1.agric.gov.ab.ca/\$department/deptdocs.nsf/all/sag6903) 
Abbreviations:

Drainage: VR - very rapid; R - rapid; W - well; MW - moderately well; I - imperfect; P - poor; VP - very poor.

Calc (calcareousness) and Salinity: N - non; W - weak; M - moderate

PM1 (upper parent material), PM2 (lower parent material):

PM Texture: VC - very coarse; C - coarse; GRVC - gravelly very coarse; MC - moderately coarse; GRMC - gravelly moderately coarse; ME - medium; MF - moderately fine; FI - fine;

PM Type: TILL - glacial till, or morainal; GLFL - glaciofluvial; FLUV - fluvial; FLEO - fluvioeolian; GLLC - glaciolacustrine; SRFS - soft rock; FNPT - fen peat; SPPT - sphagnum peat; UNDM - undetermined

Soil Subgroup: Defined below (Table 4, based on the Canadian System of Soil classification)

Subgroup modifier: CRSA - carbonated and saline

Table 4. Soil Orders and Great Groups in the Edmonton East Map Sheet

\begin{tabular}{|c|c|c|}
\hline Order & Great Group & Subgroups \\
\hline $\begin{array}{l}\text { Brunisolic - Sufficient development } \\
\text { to exclude from the Regosolic } \\
\text { order, but lack degrees or kinds of } \\
\text { development specified for other } \\
\text { orders. } \\
\end{array}$ & $\begin{array}{l}\text { Eutric Brunisol - } A h<10 \mathrm{~cm}, \mathrm{pH}>5.5 \\
\text { Dystric Brunisol }-\mathrm{Ah}<10 \mathrm{~cm}, \mathrm{pH}<5.5\end{array}$ & $\begin{array}{l}\text { E.EB - Eluviated Eutric Brunisol } \\
\text { E.DYB - Eluviated Dystric Brunisol }\end{array}$ \\
\hline $\begin{array}{l}\text { Regosolic - Development too weak } \\
\text { to meet requirements of any other } \\
\text { Order. }\end{array}$ & $\begin{array}{l}\frac{\text { Regosol }-A h<10 \mathrm{~cm}, \mathrm{Bm} \text { absent or }<5}{\mathrm{~cm}} \\
\text { Humic Regosol }-\mathrm{Ah} \leq 10 \mathrm{~cm}, \mathrm{Bm} \text { absent } \\
\text { or }<5 \mathrm{~cm}\end{array}$ & (Not in above table) \\
\hline $\begin{array}{l}\text { Chernozemic - Surface horizons } \\
\text { darkened by accumulation of } \\
\text { organic matter from decomposition } \\
\text { of grassland vegetation. }\end{array}$ & $\begin{array}{l}\text { Black Chernozem - Black Ah, semiarid } \\
\text { climate } \\
\text { Dark Gray Chernozem - Dark Gray Ah, } \\
\text { semiarid climate }\end{array}$ & $\begin{array}{l}\text { O.BL - Orthic Black } \\
\text { E.BL - Eluviated Black } \\
\text { SZ.BL - Solonetzic Black } \\
\text { O.DG - Orthic Dark Gray }\end{array}$ \\
\hline $\begin{array}{l}\text { Gleysolic - Features indicative of } \\
\text { periodic or prolonged water } \\
\text { saturation, and reducing conditions } \\
\text { - mottling and gleying. }\end{array}$ & $\begin{array}{l}\text { Humic Gleysol - } A h \geq 10 \mathrm{~cm} \text {, no Bt } \\
\text { Gleysol - Ah } \leq 10 \mathrm{~cm} \text {, no Bt } \\
\text { Luvic Gleysol - Has a Btg, usually has } \\
\text { an Ahe or an Aeg }\end{array}$ & $\begin{array}{l}\text { R.HG - Rego Humic Gleysol } \\
\text { SZ.HG - Solonetzic Humic Gleysol } \\
\text { Various Gleysol subgroups occur in } \\
\text { ZGW units (Table 3), including: } \\
\text { O.LG - Orthic Luvic Gleysol } \\
\text { HU.LG - Humic Luvic Gleysol } \\
\text { O.G - Orthic Gleysol } \\
\end{array}$ \\
\hline $\begin{array}{l}\text { Luvisolic - Light coloured eluvial } \\
\text { horizons - Ae; illuvial B horizons of } \\
\text { silicate clay accumulation - Bt; } \\
\text { developed under forest vegetation. }\end{array}$ & $\begin{array}{l}\text { Gray Luvisol - May or may not have Ah, } \\
\text { has Ae and Bt, usually MAST } \leq 8 \\
\text { degrees Celsius }\end{array}$ & $\begin{array}{l}\text { O.GL - Orthic Gray Luvisol } \\
\text { D.GL - Dark Gray Luvisol } \\
\text { GL.GL - Gleyed Gray Luvisol } \\
\text { GLD.GL - Gleyed Dark Gray Luvisol } \\
\text { BR.GL - Brunisolic Gray Luvisol } \\
\end{array}$ \\
\hline $\begin{array}{l}\text { Solonetzic - Has Solonetzic B } \\
\text { horizon - Bn or Bnt - columnar or } \\
\text { prismatic structure, hard to } \\
\text { extremely hard when dry, } \\
\text { exchangeable } \mathrm{Ca} / \mathrm{Na} \leq 10 .\end{array}$ & $\begin{array}{l}\text { Solonetz - Lack a continuous } \mathrm{Ae} \geq 2 \mathrm{~cm} \\
\text { Solodized Solonetz }-\mathrm{Ae} \geq 2 \mathrm{~cm} \text {, intact } \\
\text { columnar Bnt or } \mathrm{Bn} \\
\frac{\text { Solod }-\mathrm{Ae} \geq 2 \mathrm{~cm} \text {, distinct } \mathrm{AB} \text { or } \mathrm{BA}}{\text { (disintegrating Bnt) }}\end{array}$ & $\begin{array}{l}\text { B.SZ - Black Solonetz } \\
\text { BL.SS - Black Solodized Solonetz } \\
\text { BL.SO -Black Solod }\end{array}$ \\
\hline $\begin{array}{l}\text { Organic-Composed dominantly of } \\
\text { organic materials; most are water } \\
\text { saturated for prolonged periods. }\end{array}$ & $\begin{array}{l}\text { Mesisol - Dominantly mesic } \\
\text { Fibrisol - Dominantly fibric }\end{array}$ & $\begin{array}{l}\text { T.F. - Terric Fibrisol } \\
\text { T.M. - Terric Mesisol } \\
\text { TF.M - Terric Fibric Mesisol } \\
\text { TM.F - Terric Mesic Fibrisol } \\
\text { TY.F - Typic Fibrisol } \\
\text { M.F - Mesic Fibrisol } \\
\text { TY.M - Typic Mesisol } \\
\text { F.M - Fibric Mesisol } \\
\end{array}$ \\
\hline
\end{tabular}

z Source: Soil Classification Working Group (1998).

$\checkmark$ MAST $=$ mean annual soil temperature. 


\subsection{SOIL AND LAND COVER MAP}

Soil types, land use and distribution of surface water bodies are shown on the map 'Land Systems, Land Cover and Soil Sensitivity to Acid Inputs in the Edmonton West Map Sheet' (back pocket). The surficial materials consist mainly of glacial till, glaciolacustrine, glaciofluvial and fluvioeolian deposits. ('Fluvioeolian' refers to a complex of glaciofluvial deposits with eolian deposits occurring as blankets and dunes.) Landscapes range from undulating to hummocky. A legend accompanying the map indicates the dominant and minor soil series within each Land System, along with the parent materials and landscape features.

Land cover in the study area was categorized as cultivated, grassland, shrubland, treed land, wetland or other land. The distribution and extent of these land cover types is indicated in the Land System map (back pocket).

\subsection{DESCRIPTION OF SAMPLED SOILS}

Locations and descriptions of soils sampled in the study area are presented in Appendix A. Analytical data for the soils are presented in Appendix B.

\subsection{SURFACE WATERS}

The largest water bodies in the area are Cooking, Bittern, Ministik, Big, Coal, Big Hay, Manawan, Joseph and Oliver Lakes. Pigeon Lake is considerably larger than these, but only a very small portion of the lake occurs within the Edmonton West study area. Lakes are most numerous in the southeast part of the study area. Lakes are relatively common immediately southwest of Edmonton, and are less common in the far southwest, west and northwest. There are very few water bodies of significant size east and northeast of Edmonton.

Many of the lakes in the study area have data reported in the Alberta Environment Online Lake Water Quality Data database (Table 5). The sensitivity of these lakes to acidification was based on the criteria provided by Palmer and Trew (1987), which is based on the total alkalinity of the lake water. The criteria are:

- High Sensitivity

- Moderate Sensitivity

- Moderate - Low Sensitivity

- Low Sensitivity

- Least Sensitive
Alkalinity $0-4 \mathrm{mg} \mathrm{L}^{-1}$

Alkalinity $5-8 \mathrm{mg} \mathrm{L}^{-1}$

Alkalinity $9-25 \mathrm{mg} \mathrm{L}^{-1}$

Alkalinity $26-40 \mathrm{mg} \mathrm{L}^{-1}$

Alkalinity $>40 \mathrm{mg} \mathrm{L}^{-1}$

Based on the water quality of lakes reported in the Edmonton West study area, all lakes have alkalinity levels that greatly exceed levels in the above criteria and can be regarded as "Least Sensitive". Palmer and Trew (1987) did not categorize any lakes in the Edmonton area as being more sensitive than the "Least Sensitive".

The Alberta environment database does not include data for many of the small lakes in the Edmonton area. The two sampled lakes (Longhurst and Unnamed) were characterized by high $\mathrm{pH}$. Additional water chemistry data was not obtained for these samples as high $\mathrm{pH}$ values correlate with high alkalinity, and the lakes were therefore considered to be in the 'Least sensitive' category. 
It was concluded that all, or almost all, surface waters in the Edmonton West can be categorized as having Low sensitivity to acidifying inputs. Derivation of critical loads was not, therefore, carried out for any of the surface waters in the study area.

Table 5. Water Chemistry of Lakes in the Edmonton West Study Area

\begin{tabular}{|c|c|c|c|c|c|c|c|}
\hline Lake & Location & $\mathrm{pH}$ & $\begin{array}{c}\mathrm{Ca} \\
\left(\mathrm{mg} \mathrm{L}^{-1}\right)\end{array}$ & $\begin{array}{c}\text { Alkalinity } \\
\left(\mathrm{mg} \mathrm{L}^{-1} \mathrm{CaCO}_{3}\right)\end{array}$ & $\begin{array}{c}\text { TDS } \\
\left(\mathrm{mg} \mathrm{L}^{-1}\right)\end{array}$ & $\begin{array}{c}E C \\
\left(\mu \mathrm{S} \mathrm{cm}^{-1}\right)\end{array}$ & $\begin{array}{l}\text { Acidification } \\
\text { Sensitivity }\end{array}$ \\
\hline Big Island & 16/17-53-22-W4 & 9.4 & 23 & 132 & 227 & 390 & Low \\
\hline Big Lake & $53-25 \& 26-W 4$ & 8.9 & 48 & 141 & 348 & 564 & Low \\
\hline Bittern & $7-47-21-W 4$ & - & - & 914 & 1,830 & - & Low \\
\hline Boag & $30-52-22-W 4$ & 9.4 & 28 & 132 & 235 & 390 & Low \\
\hline Coal & 27-47-23-W4 & 8.8 & 31 & 200 & 288 & 470 & Low \\
\hline Cooking & 13-51-22-W4 & 8.8 & 22 & 419 & 927 & 1,410 & Low \\
\hline Half Moon & $6-52-21-W 4$ & 8.7 & 19 & 136 & 156 & 294 & Low \\
\hline Islet & $2-52-20-W 4$ & 8.4 & 32 & 167 & 173 & 316 & Low \\
\hline Joseph & $6-50-21-W 4$ & 7.9 & 25 & 109 & 117 & 214 & Low \\
\hline Long Lake & 15-47-27-W4 & 8.8 & 20 & 115 & 133 & 244 & Low \\
\hline Longhurst $^{2}$ & 36-51-1-W5 & 8.4 & - & - & - & - & Low \\
\hline Looking Back & 15-50-22-W4 & 8.9 & 36 & 302 & 1,011 & - & Low \\
\hline Manawan & $5-57-25-W 4$ & 8.9 & 44 & 107 & 379 & 612 & Low \\
\hline Ministik & $34-50-21-W 4$ & 9.1 & 53 & 752 & 2,428 & - & Low \\
\hline Pigeon & 10/14-47-28-W4 & 8.4 & 26 & 144 & 155 & 290 & Low \\
\hline Telford & $36-49-25-W 4$ & - & - & 140 & 298 & - & Low \\
\hline Twin Island & $10-52-22-W 4$ & - & - & 256 & 754 & - & Low \\
\hline Unnamed $^{2}$ & $32-51-27-W 4$ & 8.3 & - & - & - & - & Low \\
\hline Wizard & $5-48-27-W 4$ & 8.3 & 28 & 158 & 177 & 330 & Low \\
\hline
\end{tabular}

${ }^{\mathrm{Z}}$ Lakes sampled in the study area; all other lake data from Alberta Environment Online Lake Water Quality Data database.

\subsection{EMPIRICAL METHOD}

The empirical method as adapted in the UK from the Skokloster approach (Section 2.4) was applied to soils in the Edmonton West study area. The application of this approach begins with allocation of a soil to a particular sensitivity and critical load class (Table 6). This scheme places clay minerals in the second class. However, the exchange capacity and exchangeable cations carried by clay minerals are not taken into account, and placing a clayey soil into Class 2 was not considered as being appropriate (Hornung et al. 1995). Therefore, a particle size classification was developed for modifying the initial mineralogically-based classes (Table 7). In addition to the soil textural modifiers, various other factors were considered in determining the final classification ratings for different soil types (Table 8 ). As an example, a soil overlying quartzite bedrock would be allocated to Class 1 in the Skokloster classification system. 
However, if the soil was poorly drained and loamy-sand in texture, it would be allocated to Class 2 , with a higher critical load. Similarly, if the soil was a deep sand, it would also be allocated to Class 2.

Table 6. Mineralogical Classification and Critical Loads for Soils $(0-0.5 \mathrm{~m})$ According to the Skokloster Classification ${ }^{2}$

\begin{tabular}{|c|l|c|}
\hline Class & \multicolumn{1}{|c|}{ Dominant Weatherable Minerals } & \multicolumn{1}{|c|}{$\begin{array}{c}\text { Critical Load } \\
\left(\mathbf{k m o l ~ H}^{+} \mathbf{h a}^{-1} \mathbf{~ y r}^{-1}\right)\end{array}$} \\
\hline 1 & $\begin{array}{l}\text { Quartz, rutile, anatase, kaolinite, gibbsite, } \\
\text { orthoclase }\end{array}$ & $<0.2$ \\
\hline 2 & $\begin{array}{l}\text { Muscovite, plagioclase, illite, montmorillonite, } \\
\text { vermiculite }\end{array}$ & $0.2-0.5$ \\
\hline 3 & $\begin{array}{l}\text { Amphibole, chlorite, biotite, epidote, } \\
\text { glaucophane }\end{array}$ & $0.5-1.0$ \\
\hline 4 & Olivine, garnets, pyroxenes, epidote & $1.0-2.0$ \\
\hline 5 & Carbonates & $>2.0$ \\
\hline
\end{tabular}

${ }^{2}$ After Nilsson and Grennfelt (1988) and Sverdrup and Warfvinge (1988)

Table 7. Allocation to Skokloster Material Class Based on Particle Size Class z

\begin{tabular}{|l|c|}
\hline \multicolumn{1}{|c|}{ Particle size class } & Soil material class \\
\hline Sand, loamy sand, sandy loam, (sandy) silt loam & Class 2 \\
\hline Clay loam, sandy clay loam, silt loam & Class 3 \\
\hline Clay, silty clay, sandy clay & Class 4 \\
\hline
\end{tabular}

${ }^{2}$ After Hornung et al. (1995).

Table 8. Factors Causing a Decrease or Increase in Critical Loads of Acidity for Soils ${ }^{2}$

\begin{tabular}{|l|c|c|}
\hline \multicolumn{1}{|c|}{ Factor } & Decrease & Increase \\
\hline Precipitation & High & Low \\
\hline Vegetation & Coniferous forest & Deciduous forest \\
\hline Elevation slope & High & Low \\
\hline Soil texture & See Table 7 & See Table 7 \\
\hline Soil drainage & Free & Impeded \\
\hline Soil/till depth & Shallow & Thick \\
\hline Sulphate adsorption capacity & Low & High \\
\hline Base cation deposition & Low & High \\
\hline
\end{tabular}

${ }^{\mathrm{z}}$ After Nilsson and Grennfelt (1988) and Hornung et al. (1995).

The combination of mineralogical and particle size classes of sand to sandy loam soils in the study area would result in allocation to a critical load category of $0.2-0.5 \mathrm{kmol} \mathrm{ha}^{-1} \mathrm{yr}^{-1}$ (class 2). In the UK approach, the critical load is either increased or decreased, depending on various modifying factors, as indicated above. The factors of low precipitation, low elevation, and thick soil would increase the critical load. However, the factors of free drainage and low sulphate adsorption capacity serve to reduce the critical load. The base cation deposition rate is another modifying factor; the level in the study area, however, is of intermediate magnitude (Cheng et al. 1997 ) and therefore has little impact on the overall rating. The factors more or less balance 
each other, and we therefore deduce that very sandy soils (sand, loamy sand) likely have a critical load in the range of $0.2-0.5 \mathrm{kmol} \mathrm{ha}^{-1} \mathrm{yr}^{-1}$. This would apply particularly to soils with low organic matter content. The classification for sandy loam soils is likely in the upper part of the range, and possibly in the $0.5-1.0 \mathrm{kmol} \mathrm{ha}^{-1} \mathrm{yr}^{-1}$ range. Allocation of soil units using this empirical method leads to the assignment of critical loads in the Edmonton West study area as presented in Table 9.

\section{Table 9. Critical Loads of Soils in the Edmonton West Area Based on the Empirical Method}

\begin{tabular}{|l|l|l||}
\hline \multicolumn{1}{|c|}{ Texture } & \multicolumn{1}{c|}{ Soil Series } & \multicolumn{1}{c|}{ Critical Load } \\
\hline Very coarse & Primula, Nestow, Mundare, Helliwell & $0.2-0.5 \mathrm{kmol} \mathrm{ha}^{-1} \mathrm{yr}^{-1}$ \\
\hline Moderately coarse & Peace Hills, Redwater & $0.5-1.0 \mathrm{kmol} \mathrm{ha}^{-1} \mathrm{yr}^{-1}$ \\
\hline Medium to moderately fine & Series on till & $1.0-2.0 \mathrm{kmol} \mathrm{ha}^{-1} \mathrm{yr}^{-1}$ \\
\hline Fine & Glaciolacustrine clays & $>2.0 \mathrm{kmol} \mathrm{ha}^{-1} \mathrm{yr}^{-1}$ \\
\hline
\end{tabular}

\subsubsection{Model Description}

The Steady State Mass Balance (SSMB) model considers the soil as consisting of one compartment equal to the thickness of the root zone (generally $30-50 \mathrm{~cm}$ or more in forest soils), and calculates critical loads in relation to critical chemical values related to element concentrations leaching from the root zone. The calculation of critical loads using the SSMB model is based on a balance of sources of acidity against sinks for acidity and sources of alkalinity, and uses a formulation of the charge balance of ions in the soil leachate.

Sverdrup and de Vries (1994) and de Vries (1991) provided description and derivation of the model, and the model as applied in Europe is described in UBA (2004). The method was applied in calculating critical loads of acid deposition for forest soils in eastern Canada and most recently in Manitoba and Saskatchewan forested areas (Aherne and Watmough 2006). Some model assumptions in an earlier approach, applied in the study of critical loads in the ProvostEsther area in Alberta (Turchenek and Abboud 2001), differ from those applied in the recent Canadian studies. The method applied herein is as described in the Canadian studies, with emphasis on the Manitoba/Saskatchewan study, from which some of the input data were obtained. The critical load of acidity arising from sulphur, $C L(S)$, and from nitrogen, $C L(N)$, is described by the following equation:

$$
\mathrm{CL}(\mathrm{S})+\mathrm{CL}(\mathrm{N})=\mathrm{BC}_{\text {dep }}-\mathrm{Cl}_{\text {dep }}+\mathrm{BC}_{\mathrm{w}}-\mathrm{BC}_{\mathrm{u}}+\mathrm{N}_{\mathrm{i}}+\mathrm{N}_{\mathrm{u}}+\mathrm{N}_{\mathrm{de}}-A \mathrm{k}_{\mathrm{le} \text { (crit) }}
$$

where, $\mathrm{BC}_{\text {dep }}$ is base cation deposition $\left(\mathrm{BC}=\mathrm{Ca}^{2+}+\mathrm{Mg}^{2+}+\mathrm{K}^{+}+\mathrm{Na}^{+}\right), \mathrm{Cl}_{\text {dep }}$ is $\mathrm{Cl}^{-}$deposition, $B C_{w}$ is base cation weathering, $N_{i}$ is nitrogen immobilization, $N_{u}$ is nitrogen uptake by

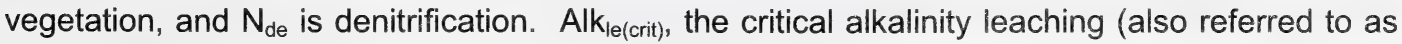
critical acid neutralizing capacity) is estimated from the critical base cation to aluminum ratio (BC:Al) in the soil solution that leaches through the system along with a term that describes the gibbsite equilibrium, which is assumed to control the Al concentration. 
Critical load has also been defined in terms of potential acidity as:

$$
C L\left(A C_{p o t}\right)=B C_{w}-B C_{u}+N_{i}+N_{u}+N_{d e}-A l k_{\text {le(crit) }}
$$

$\mathrm{BC}_{\text {dep }}$ nor $\mathrm{Cl}_{\text {dep }}$ are not considered in the definition because they are ecosystem properties and can change over time (UBA, 2004). The nitrogen terms have been assumed to be nil or very close to nil in applications to Canadian soils, and removal of base cations is generally not considered. In forest soils, base cations would be removed by harvesting; in grassland situations, this term would be minimal as the main export of cations would be via livestock. Since cations are not removed, the $\mathrm{BC}_{u}$ term is considered to be nil. The critical load potential acidity is then defined as:

$$
\mathrm{CL}\left(\mathrm{Ac}_{\mathrm{pot}}\right)=\mathrm{BC}_{\mathrm{w}}-\mathrm{Alk}_{\mathrm{le}(\text { crit })}
$$

Critical 'Alkalinity leaching' (Alk $\left.\mathrm{k}_{\mathrm{le}(\mathrm{crit})}\right)$ can be defined in terms of soil acidity as follows:

$$
A l k_{l e(\text { crit })}=-A l_{l e(\text { crit })}-H_{l e(\text { crit })}=-Q \cdot\left([A l]_{\text {crit }}+[H]_{\text {crit }}\right)
$$

$Q$ is the precipitation surplus, or water leaving the root zone $\left(\mathrm{m}^{3} / \mathrm{ha} / \mathrm{yr}\right)$, and the square brackets denote concentrations (in $\mathrm{eq} / \mathrm{m}^{3}$ ).

The relationship between $\mathrm{Al}$ and $\mathrm{H}$ is defined by the gibbsite equilibrium:

$$
[\mathrm{Al}]=\mathrm{K}_{\mathrm{gibb}} \bullet[\mathrm{H}]^{3} \text { or }[\mathrm{H}]=\left([\mathrm{Al}] / \mathrm{K}_{\mathrm{gibb}}\right)^{1 / 3}
$$

The Alk $\mathrm{k}_{\text {lecrit) }}$ term is then defined as,

$$
\begin{aligned}
A^{A_{1}(\text { crit })} & =-Q^{2 / 3} \cdot\left\{1.5 \cdot\left(B C_{\text {dep }}+B C_{w}-B C_{u}\right) /\left((B C: A l)_{\text {crit }} \cdot K_{\text {gibb }}\right)\right\}^{1 / 3} \\
& \left.-1.5 \cdot\left(B C_{\text {dep }}+B C_{w}-B C_{u}\right) /(B C: A l)_{\text {crit }}\right)
\end{aligned}
$$

where $Q$ is the precipitation surplus, or water leaving the root zone $\left(\mathrm{m}^{3} \mathrm{ha}^{-1} \mathrm{yr}^{-1}\right)$. Values for the parameters are presented in the following section. $\mathrm{K}_{\text {gibb }}$ is the gibbsite equilibrium constant.

The incorporation of these relationships in the CL expression (equation 8) provides the SSMB equation for critical load of acidity in $\mathrm{mol} \mathrm{ha}^{-1} \mathrm{yr}^{-1}$, as follows:

$$
\begin{gathered}
C L\left(A C_{p o t}\right)=B C_{w}+\left\{1.5 \cdot\left(B C_{w}+B C_{\text {dep }}-B C_{u}\right) /\left((B C: A l)_{\text {crit }} \cdot K g i b b\right)\right\}^{1 / 3} \cdot Q^{2 / 3} \\
\left.+1.5 \cdot\left(B C_{w}+B C_{\text {dep }}-B C_{u}\right) /(B C: A l)_{\text {crit }}\right)
\end{gathered}
$$

$Q$ is the precipitation surplus, or water leaving the root zone $\left(\mathrm{m}^{3} \mathrm{ha}^{-1} \mathrm{yr}^{-1}\right)$. Values for the parameters are presented in the following section.

The full derivation of the equation and the explanation of factors used in the $\mathrm{ANC}_{\text {le(crit) }}$ term can be found in UBA (2004).

\subsubsection{Data for Critical Load Calculations}

\section{Precipitation Surplus (Q)}

$Q$ is calculated as the precipitation minus the sum of interception evaporation by vegetation, the actual soll evaporation and the actual transpiration (water uptake) in the root zone. The precipitation surplus term is discussed in Section 5.3.1.3. The SSMB calculations were carried 
out for a $75 \mathrm{~cm}$ soil layer, which is consistent with the approach elsewhere in Canada (Aherne and Watmough 2006). For the ARC model (Section 5.3.1.3), the estimate is $780 \mathrm{~m}^{3} \mathrm{ha}^{-1} \mathrm{yr}^{-1}$ for percolation out of the $25 \mathrm{~cm}$ soil layer, and the estimate for percolation below the $75 \mathrm{~cm}$ depth is $200 \mathrm{~m}^{3} \mathrm{ha}^{-1} \mathrm{yr}^{-1}$.

\section{Gibbsite Equilibrium Constant ( $K_{\text {gibb }}$ )}

The value of $\mathrm{K}_{\text {gibb }}$ depends on soil type and the organic matter content. The value for soils with low organic matter ranges from $300-3,000 \mathrm{~m}^{6} \mathrm{~mol}^{-2}$ (UBA 2004). $\mathrm{K}_{\text {gibb }}=300 \mathrm{~m}^{6} \mathrm{~mol}_{\mathrm{c}}^{-2}$ was applied in modelling for the Edmonton West grid cell.

\section{Weathering Rates (BCw)}

A number of options for estimating weathering rates are presented by the Task Force on Mapping (1996) and more recently in UBA (2004), and were previously described in detail by Sverdrup and de Vries (1994) and Sverdrup (1990). Application of these methods to data presented by Sverdrup (1990) for sandy soils suggests that the weathering rate is in the range of 0.05 to $0.4 \mathrm{kmol}_{\mathrm{c}} \mathrm{ha}^{-1} \mathrm{yr}^{-1}$ for a 1 metre soil layer, or about 0.01 to $0.1 \mathrm{kmol}_{\mathrm{c}} \mathrm{ha}^{-1} \mathrm{yr}^{-1}$ for a 0.25 metre layer. A value of $0.07 \mathrm{kmol}_{\mathrm{c}} \mathrm{ha}^{-1} \mathrm{yr}^{-1}$ for a $0.25 \mathrm{~m}$ layer has been determined for sandy soils in Minnesota by Bloom and Grigal (1985), and was subsequently considered as a suitable approximation for sandy soils in Alberta by Abboud and Turchenek (1990), Turchenek and Abboud (2001) and Turchenek et al. (1994). This rate was therefore applied to soils in the Edmonton West grid cell.

In keeping with SSMB applications in other parts of Canada, a $0.75 \mathrm{~m}$ soil layer was applied in modelling. Although most plant roots generally occur within the uppermost soil horizon, the depth of soil exploited by roots can be much deeper. Weathering rates are described further in Section 5.3.1.1. The weathering rate of $0.07 \mathrm{kmol}_{\mathrm{c}} \mathrm{ha}^{-1} \mathrm{yr}^{-1} 0.25 \mathrm{~m}^{-1}$ (from Turchenek and Abboud 2001) was applied in the case of sandy soils. The equivalent $0.75 \mathrm{~m}$ weathering rate is $0.21 \mathrm{kmol}_{\mathrm{c}} \mathrm{ha}^{-1} \mathrm{yr}^{-1}\left(210 \mathrm{~mol}_{\mathrm{c}} \mathrm{ha}^{-1} \mathrm{yr}^{-1}\right.$ applied in the model). For other textures, the weathering rates were as follows (expressed as $\mathrm{mol} \mathrm{ha}^{-1} \mathrm{yr}^{-1}$ ): loamy sand to sand soil - 300; sandy loam 450; loam - 750; clay loam -1,500; and clay or heavy clay -3,000.

\section{Growth Uptake or Export of Base Cations ( $\left.B c_{u}\right)$}

Over a long-term, the net uptake of base cations $\left(\mathrm{BC}_{u}, \mathrm{Ca}, \mathrm{Mg}\right.$ and $\mathrm{K}$, with $\mathrm{Na}$ excluded) is equal to that stored in vegetative biomass. In the case of grasslands, annual growth (biomass) is returned to the soil each year, and cation storage levels in biomass are considered to be negligible. Nutrients can also be "exported" from soils through livestock grazing and removal of livestock from the land. Little data is available for nutrient removal rates from rangelands by animals. Heady and Child (1994) reported exports of 0.025 to $0.035 \mathrm{kmol}_{\mathrm{c}} \mathrm{ha}^{-1} \mathrm{yr}^{-1}$ of base cations from rangelands in New Mexico. These data suggest that export of nutrients by beef production is low, and rates for northern climates on poor soils would likely be even lower, due to lower stocking rates. Therefore, base cation export by animals is considered as negligible for purposes of deriving critical loads by the SSMB or other methods, and was set to zero in the model runs. 


\section{BC:Al Ratio}

Base cation to aluminum ratios used in the calculations was 1, 10, 45 and 250 (see Section 2.2.2).

\subsubsection{Critical Load Calculations}

Critical loads were calculated using the SSMB model (equation 8 ) for a $0.75 \mathrm{~m}$ soil layer. Critical load calculation by the SSMB method was not conducted on the basis of properties of the soil samples, but rather on the basis of weathering rates of broad soil groupings (sand, sand to loamy sand, sandy loam, loam, and clay loam soils) and on regional variation in climate expressed as variation in precipitation surplus. Base cation export was assumed to be negligible.

The results of SSMB calculations (Table 10) showed that critical loads at the BC:Al ratio of 2 are one and a half to two times greater than those at BC:Al ratios of 10. (Note: The expression 'BC' is used heretofore, although it is equivalent to 'Bc' defined above.) However, increasing the $\mathrm{BC}: \mathrm{Al}$ ratio beyond 10 reduced the critical load only slightly. The lowest critical loads were obtained for the sandy to loamy sand soils.

Table 10. Critical Load Calculations by the SSMB Method

\begin{tabular}{|c|c|c|c|c|c|c|c|}
\hline \multirow[b]{2}{*}{ Soil Type } & \multirow[b]{2}{*}{$\begin{array}{l}\text { Texture } \\
\text { Group }\end{array}$} & \multirow{2}{*}{$\begin{array}{l}\text { Soil } \\
\text { Texture } \\
\text { Group }\end{array}$} & \multirow[b]{2}{*}{$\begin{array}{l}\text { Major Soil } \\
\text { Series }\end{array}$} & \multicolumn{4}{|c|}{ Critical Load (kmol ha $\left.{ }^{-1} \mathrm{yr}^{-1}\right)$} \\
\hline & & & & $\begin{array}{c}\text { BC:Al } \\
1\end{array}$ & $\begin{array}{c}\text { BC:Al } \\
10\end{array}$ & $\begin{array}{l}\text { BC:Al } \\
45\end{array}$ & $\begin{array}{l}\text { BC:Al } \\
250\end{array}$ \\
\hline $\begin{array}{l}\text { Eluviated Dystric Brunisol } \\
\text { Eluviated Eutric Brunisol }\end{array}$ & Very Coarse & $\begin{array}{l}\text { Sand, } \\
\text { Loamy } \\
\text { Sand }\end{array}$ & \begin{tabular}{|l|} 
Nestow \\
Primula \\
Tiger Lily \\
\end{tabular} & 0.6 & 0.3 & 0.2 & 0.2 \\
\hline $\begin{array}{l}\text { Eluviated Black Chernozem } \\
\text { Dark Gray Chernozem }\end{array}$ & \begin{tabular}{|l} 
Very Coarse : \\
Moderately \\
Coarse
\end{tabular} & $\begin{array}{l}\text { Loamy } \\
\text { Sand }\end{array}$ & $\begin{array}{l}\text { Helliwell } \\
\text { Mundare }\end{array}$ & 0.7 & 0.4 & 0.4 & 0.3 \\
\hline $\begin{array}{l}\text { Orthic Black Chernozem } \\
\text { Eluviated Black Chernozem } \\
\text { Dark Gray Chernozem } \\
\text { Dark Gray Luvisol } \\
\end{array}$ & $\begin{array}{l}\text { Moderately } \\
\text { Coarse }\end{array}$ & $\begin{array}{l}\text { Sandy } \\
\text { Loam }\end{array}$ & $\begin{array}{l}\text { Peace Hills } \\
\text { Elk Point }\end{array}$ & 1.0 & 0.6 & 0.5 & 0.5 \\
\hline $\begin{array}{l}\text { Black Chernozem } \\
\text { Eluviated Black Chernozem } \\
\text { Dark Gray Chernozem } \\
\text { Gray Luvisol }\end{array}$ & Medium & $\begin{array}{l}\text { Loam, Silt } \\
\text { Loam }\end{array}$ & $\begin{array}{l}\text { Ponoka } \\
\text { Hobbema } \\
\text { Glory }\end{array}$ & 1.6 & 1.0 & 0.8 & 0.8 \\
\hline $\begin{array}{l}\text { Orthic Gray Luvisol } \\
\text { Dark Gray Luvisol } \\
\text { Orthic Black Chernozem } \\
\text { Eluviated Black Chernozem } \\
\text { Dark Gray Chernozem } \\
\text { Black Solodized Solonetz } \\
\text { Solonetzic Black Chernozem }\end{array}$ & $\begin{array}{l}\text { Medium, } \\
\text { Moderately } \\
\text { Fine }\end{array}$ & $\begin{array}{l}\text { Sandy Clay } \\
\text { Loam } \\
\text { Clay Loam }\end{array}$ & \begin{tabular}{|l|} 
Benalto \\
Breton \\
Cooking lake \\
Dnister \\
Uncas \\
Rolly View \\
Angus Ridge \\
Falun \\
Highvale \\
Camrose \\
Kavanagh \\
Kehiwin \\
Spedden \\
Winterburn \\
\end{tabular} & 2.9 & 1.8 & 1.6 & 1.5 \\
\hline $\begin{array}{l}\text { Orthic Black Chernozem } \\
\text { Eluviated Black Chernozem } \\
\text { Dark Gray Chernozem } \\
\text { Black Solonetz }\end{array}$ & Fine, Very Fine & $\begin{array}{l}\text { Clay } \\
\text { Heavy Clay }\end{array}$ & $\begin{array}{l}\text { Malmo } \\
\text { Macola } \\
\text { Duagh } \\
\text { Wetaskiwin } \\
\end{array}$ & 5.6 & 3.6 & 3.2 & 3.1 \\
\hline
\end{tabular}

"Major soil" occurring in study area Land Systems, from Table 2. 


\subsection{ARC MODEL}

The ARC model simulates mineral soil chemical processes directly related to acidity and acidification of soils, and predicts the associated soil properties of $\mathrm{pH}$, base saturation, solution $\mathrm{Al}^{3+}$ concentration and base cation to aluminum (BC:Al) ratio. The ARC model is described in detail in Turchenek and Abboud (1988), and Abboud et al (2002). This model is adapted from the Bloom and Grigal (1985) model, and modified to a two-layer model by calculation of acidification in the LFH and the mineral layers separately. Other modifications include calculations of acid inputs and acidification processes, method of output of model results, and inclusion of calculations for base cation to aluminum (BC:Al) ratio. These are described in greater detail in the following sections.

\subsubsection{Data for Critical Load Determinations}

The model requires climatic, soil and acid input data with a provision for varying time period for exposure and a varying time increment for reporting simulation results.

\subsubsection{Soil Data Inputs}

Soil data inputs for the ARC model are as follows:

$\mathrm{pH}$ - by the water paste method; if the $\mathrm{pH}$ data were reported in a $\mathrm{CaCl}_{2}$ solution (1:2), then use the following equations (developed for mineral soils from a correlation of $\mathrm{pH}$ values using data from Pauls et al. (1996)) was used to transform into a water paste $\mathrm{pH}$ :

for $\mathrm{LFH}$ horizons: $\mathrm{pH}\left(\mathrm{H}_{2} \mathrm{O}\right)=0.96 \mathrm{pH}\left(\mathrm{CaCl}_{2}\right)+0.55 \quad \mathrm{R}^{2}=0.989, \mathrm{n}=65$ samples

for mineral horizons: $\mathrm{pH}\left(\mathrm{H}_{2} \mathrm{O}\right)=0.94 \mathrm{pH}\left(\mathrm{CaCl}_{2}\right)+0.72 \mathrm{R}^{2}=0.984, \mathrm{n}=130$ samples

Cation exchange capacity and exchangeable bases - by the ammonium acetate extraction method.

Partial pressure of $\mathrm{CO}_{2}$ - assumed to be 0.005 atmosphere.

Activity coefficients of monovalent, divalent and trivalent ions - activity coefficients for each modelled soil horizon were calculated from the mean values for individual members of that series.

The activity coefficients $\left(\gamma_{i}\right)$ were calculated using the Davies equation (Lindsay 1979).

$$
\log \gamma_{i}=-A Z_{i}^{2}\left[\left\{I /\left(1+\left.\right|^{0.5}\right)\right\}-0.3 I\right]
$$

Where $A=0.509$ for water, $Z$ is ion valence and $I$ is ionic strength in moles $L^{-1}$.

The ionic strengths $(I)$ were calculated from the electrical conductivities of the saturated paste extracts (Lindsay 1979). 


$$
I=0.013 \mathrm{EC}
$$

where $\mathrm{I}$ is in moles $\mathrm{L}^{-1}$ and electrical conductivity (EC) of the saturated paste extracts in $\mathrm{dS} \mathrm{m}^{-1}$.

Initial weathering rates ( $\mathrm{kmol} \mathrm{ha}^{-1} \mathrm{yr}^{-1}$ ) for mineral soils - these varied with soil texture as discussed in Abboud et al. (2002) and shown in Table 11 below.

Table 11. Weathering Rates Suggested for Modelling Soils of Different Textures ${ }^{\mathrm{Z}}$

\begin{tabular}{|c|c|}
\hline Soil Texture & $\begin{array}{l}\text { Weathering Rate in } 25 \mathrm{~cm}_{\text {Surface Soil Layer }} \\
\qquad\left(\mathrm{kmol} \mathrm{ha}^{-1} \mathrm{yr}^{-1}\right)\end{array}$ \\
\hline Sand & 0.07 \\
\hline Loamy Sand & 0.10 \\
\hline Sandy Loam & 0.15 \\
\hline Loam, Silt Loam & 0.25 \\
\hline Clay Loam, Silty Clay Loam, Sandy Clay Loam & 0.50 \\
\hline Clay, Silty Clay & 1.00 \\
\hline
\end{tabular}

Source: Abboud et al. (2002)

The input data for soil pH, CEC, and sum of bases were the values for the LFH layer (usually less than $25 \mathrm{~cm}$ ) and the weighted mean values of mineral soil horizons within the top $25 \mathrm{~cm}$ of air-dried mineral soil. The thickness of the soil horizons and the bulk density were applied in computing the means. The calculations were made as previously documented by Turchenek and Abboud (1988).

\subsubsection{Acid Deposition Data}

The ARC model was applied using the PAI values $0.1,0.2,0.3,0.5,0.7$ and $1.0 \mathrm{kmol} \mathrm{ha}^{-1} \mathrm{yr}^{-1}$. These values were recommended for model application by the Alberta Environment staff and encompass existing PAI values and potential extreme future values encountered in the study area. The PAI values account for both wet and dry forms of acid deposition.

\subsubsection{Climate Data}

Data for precipitation and precipitation surplus as described in Abboud et al. (2002) were applied in the model. Previous applications of the model used a 'precipitation minus potential evapotranspiration' term to determine the amount of precipitation water that percolates beyond the $25 \mathrm{~cm}$ layer. This calculation results in a negative value for climates characteristic of central and southern Alberta. The precipitation surplus concept (Abboud et al. 2002) provides a more realistic approximation of the amount of water that is actually evaporated or transpired by accounting for episodes of high precipitation and deep moisture percolation.

\subsubsection{Time}

The model can be executed for any specified length of time, and simulation results can be reported for any specified increment of time within the total simulation period. Predictive soil effects data are of greatest interest in terms of the immediate and near future; i.e., the period during which pollutant emissions can be forecast. It is also of interest, from a soil development 
point of view, to determine soil responses to acid deposition over very long periods of time since changes in soils occur slowly. Three hundred years was selected for the simulation period. This time frame would not obscure the data for interpretation of short-term effects, yet would provide a longer term view of soil changes.

A one year increment of time between reported values in the simulations was selected. This increment assured that sufficient data points were obtained for determining the trends of $\mathrm{pH}$, base saturation, $\mathrm{Al}^{3+}$ levels and $\mathrm{BC}: \mathrm{Al}$ over time.

\subsubsection{Effect of Weathering}

The weathering $(r)$ of soil minerals is estimated in the model by the function,

$$
r=r_{0} 10^{-0.5(\mathrm{pH}-\mathrm{pHo})}
$$

where $r_{0}$ and $\mathrm{pH}_{0}$ are the initial conditions (Abboud et al. 2002). The $r_{0}$ value is based on soil texture as shown in Table 11, and a pH of 5.0 was applied in the equation.

\subsubsection{Summary of Data Inputs}

The starting parameters for soils used in simulations are given in Table 12. The taxonomy and some general descriptive features of the soils are indicated along with input data described previously.

\subsubsection{Computations}

The loss of bases is calculated on an annual basis from,

$$
S=I-A-C-W
$$

where $S$ is the sum of bases lost, $I$ is the effective acidity in the precipitation plus dryfall (the PAl), A is the acid leached out of the top $25 \mathrm{~cm}$ of soil, C is the decrease in bicarbonate weathering due to the decrease in soil solution $\mathrm{pH}$, and $\mathrm{W}$ is the base contribution due to weathering. At the end of each year of simulation, a new sum of bases is calculated from the sum for the previous year. New values for $\mathrm{pH}, \mathrm{Al}^{3+}$ concentration and $\mathrm{BC}$ : $\mathrm{Al}$ ratio are also calculated from equations relating $\mathrm{pH}$ with base saturation, $\mathrm{pH}$ with solution $\mathrm{Al}^{3+}$ concentration and $\mathrm{pH}$ with $\mathrm{BC}: \mathrm{Al}$ ratio. A linear function describes the relationship between $\mathrm{pH}$ and base saturation percentage of the soil. The functions have been determined previously for mineral soil orders and reported by Abboud and Turchenek (1990) and for LFH layers by Abboud et al. (2002).

\subsubsection{Changes to the ARC Model}

Several changes were made to the earlier ARC model when applied in the Oil Sands area (Abboud et al. 2002) and to the Edmonton East grid Cell (Abboud and Turchenek 2008). These included the addition of a new equation describing Al solubility in mineral soils and a new module to calculate the changes in mineral soil BC:Al ratios with changes in soil pH.

\section{Application as a Two-Layer Model}


The ARC model was modified to account for the acid interaction with the LFH layer. This modification necessitated the calculation of evapotranspiration and precipitation values for both LFH and mineral layers. The 'precipitation' number for the mineral layer was assumed to be equivalent to the quantity of percolation water passing through the LFH layer. The acid input is assumed to react with the LFH layers thereby acidifying their soil solutions and contributing the acidity to the mineral layer. Buffering in the LFH layers was assumed to arise from surface reactions (exchange, adsorption and complexation) and solution carbonate reactions. It was considered that there was no weathering in LFH layers and that there was no water buffering as in peat soils.

\section{Al Solubility}

The solubility of Al in the ARC model was assumed to follow the empirical model of Bloom and Grigal (1985), derived from Minnesota soils data. Recent changes to the ARC model, based on data from southeastern Alberta soils, resulted in the use of a more soluble form of gibbsite as an Al controlling mineral (Turchenek and Abboud 2001). During our modeling of soil chemistry in the Oil Sands area, the solubility of $\mathrm{Al}$ in mineral horizons was further evaluated using archived data from a joint Syncrude-ARC project (Pauls et al. 1996). The relationship between soluble Al and $\mathrm{pH}(\mathrm{H} 2 \mathrm{O})$ derived from data in these projects was applied in the model to determine critical loads of soils.

Figure 1 shows the solubility relationship for mineral soils in the upper $25 \mathrm{~cm}$ in the Oil Sands region. These covered several soil orders in the area. A linear relationship is evident with a significant $R^{2}$ term. This equation is similar in form to the Bloom and Grigal (1985) and Turchenek and Abboud (2001) equations and seems to imply a strong role for a mineral form controlling Al solubility. The pH coefficient in the equation (2.66) is close to the theoretical 3 required for gibbsite to be a controlling mineral, and the constant term (8.10) is close to the theoretical 8 assumed for the solubility product of gibbsite. Thus the possibility of gibbsite controlling Al solubility in these soils is strong with the likelihood of some influence from the organic matter present in the Ah horizons and/or leaching from the LFH layer. 


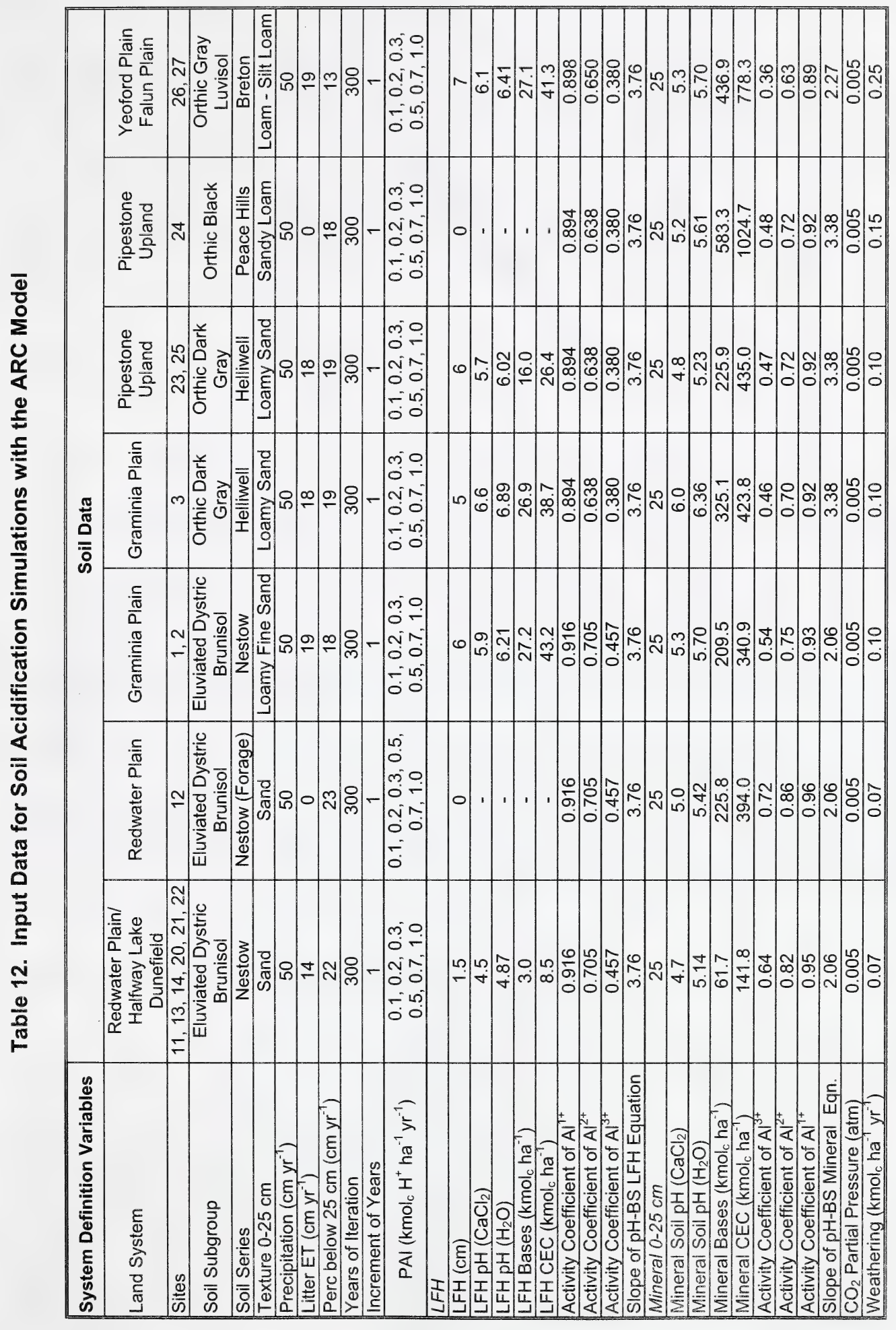




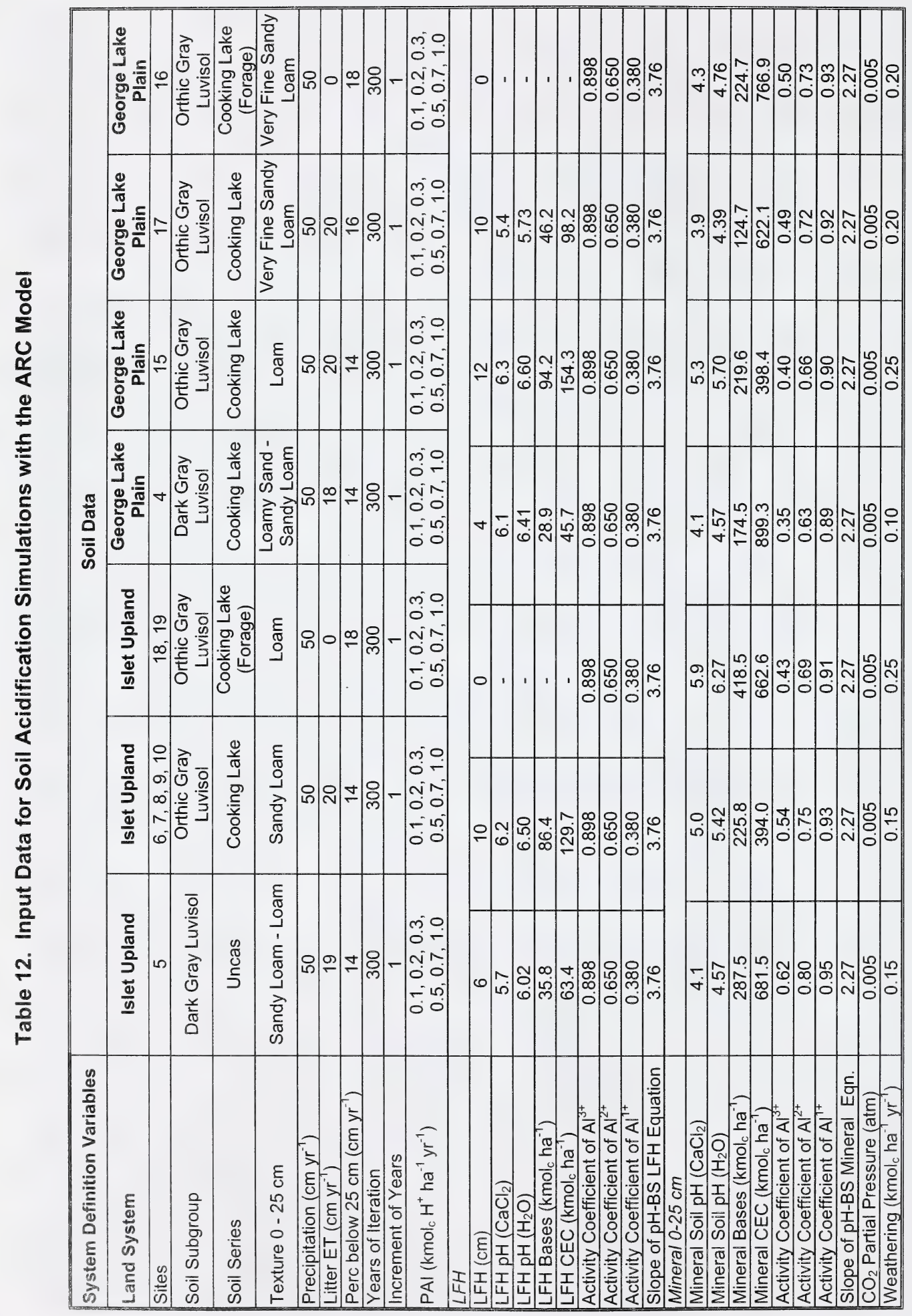

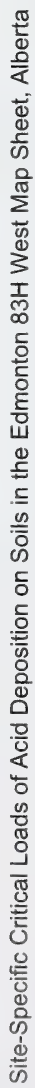




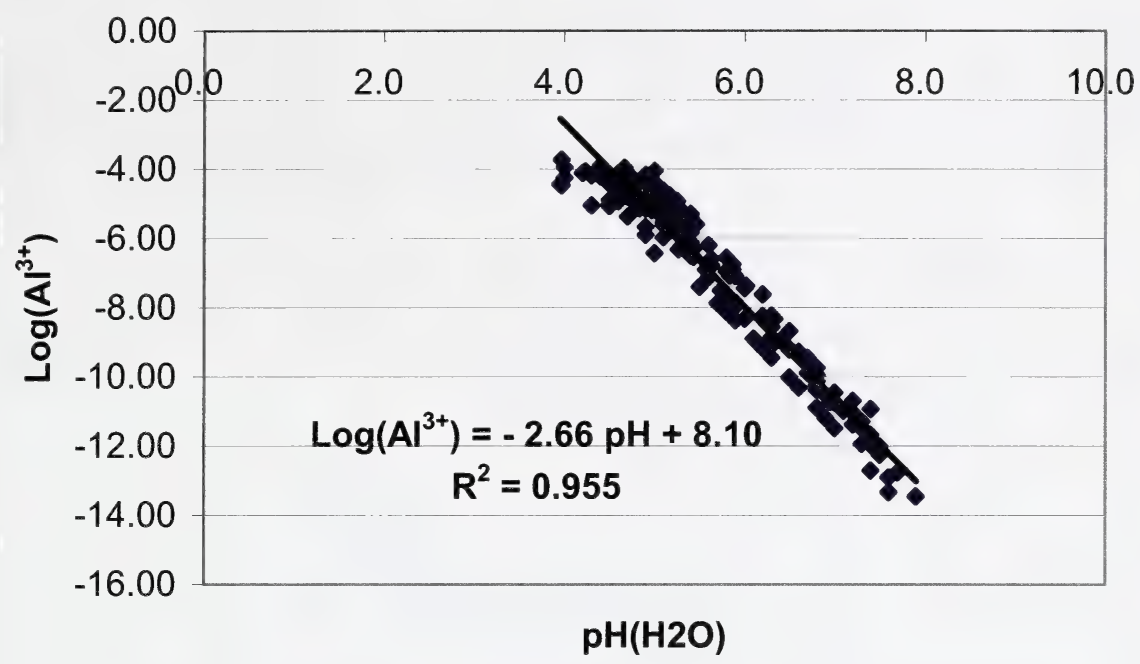

Figure 1. Al Solubility in Mineral Horizons

The $\mathrm{pH}-\mathrm{Al}$ solubility relationship was similarly derived for the LFH layers of soils. In summary, the equations applied in modelling the soils of the Edmonton West grid cell were:

for LFH horizons: $\quad \log \left[\mathrm{Al}^{3+}\right]=-2.72 \mathrm{pH}\left(\mathrm{H}_{2} \mathrm{O}\right)+8.03 \quad \mathrm{R}^{2}=0.923, \mathrm{n}=65$ samples

for 0-25 cm layer: $\quad \log \left[\mathrm{Al}^{3+}\right]=2.66 \mathrm{pH}\left(\mathrm{H}_{2} \mathrm{O}\right)+8.10 \quad \mathrm{R}^{2}=0.955, \mathrm{n}=130$ samples

\section{BC:Al Ratios}

The relationship between $\mathrm{BC}: \mathrm{Al}$ ratios and $\mathrm{pH}$ for mineral soil layers was derived from examination of soils in the oil sands region, as described in Abboud et al. (2002). An exponential relationship between $\mathrm{BC}: \mathrm{Al}$ ratios and $\mathrm{pH}$ was observed as shown in Figure 2 . This equation shows scatter that is likely due to the diverse nature of the soil orders and their mineralogy and texture, and to the influence of weathering and exchange/adsorption processes to both organic and mineral surfaces.

The $\mathrm{BC}: \mathrm{Al}$ and $\mathrm{pH}$ relationships were derived for both the mineral and the LFH layers of soils. The equations applied in modelling the soils of the Edmonton West grid cell were:

for LFH horizons: $\quad$ BC:Al Ratio $=0.12 \mathrm{e}^{1.40 \mathrm{pH}(\mathrm{H} 2 \mathrm{O})}$

for 0-25 cm layer: $\quad$ BC:Al Ratio $=0.043 \mathrm{e}^{1.14 \mathrm{pH}(\mathrm{H} 2 \mathrm{O})}$

$$
\begin{aligned}
& R^{2}=0.576, n=65 \text { samples } \\
& R^{2}=0.641, n=65 \text { samples }
\end{aligned}
$$




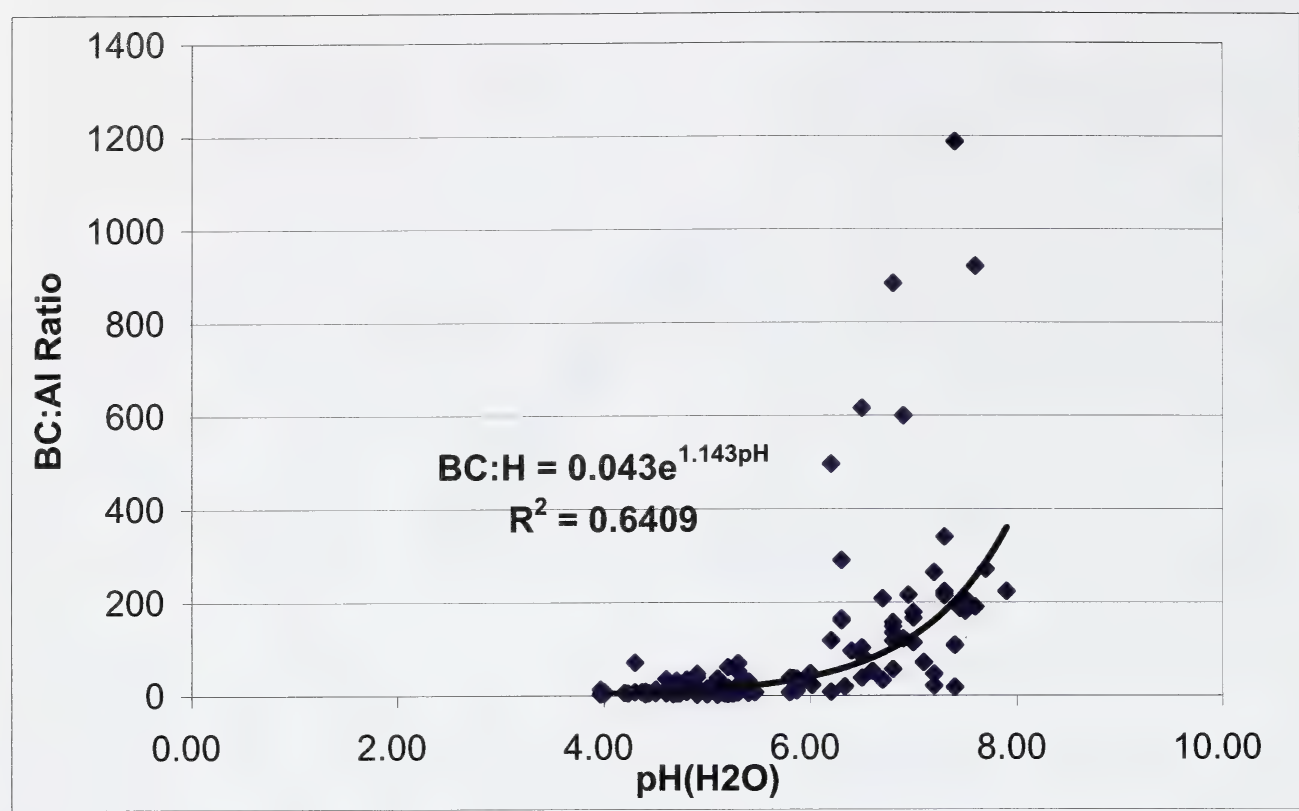

Figure 2. BC:Al Ratio for Mineral Horizons

\subsubsection{Model Execution and Data Outputs}

Computations were made for changes in soil properties on an annual basis. Output data for each time interval included: (1) year; (2) pH of soil; (3) acid input; (4) acid output; (5) protonation; (6) change in $\mathrm{pH}$; (7) base saturation; (8) sum of base cations; (9) base cations lost; (10) $\mathrm{Al}^{3+}$ concentration in soil solution, and (11) BC:Al ratio.

The outputs of major interest are the changing values of soil $\mathrm{pH}$, base saturation, and BC:Al during the time period selected. Model data were transferred to EXCEL spreadsheets to facilitate data analysis in terms of critical loads. Simulations were conducted with a desktop computer using the program RS1. Table 13 shows the model output information generated in a table.

Table 13. Example of Output from the ARC Model Simulation Processes

\begin{tabular}{|c|c|c|c|c|c|c|c|c|c|c|c|}
\hline \multicolumn{12}{|c|}{ Mineral Soil Layer } \\
\hline \multirow{2}{*}{$\begin{array}{l}\text { Time } \\
\text { (Years) }\end{array}$} & \multirow{2}{*}{$\begin{array}{c}\mathrm{pH} \\
(\mathrm{H} 2 \mathrm{O})\end{array}$} & \multirow{2}{*}{$\begin{array}{l}\text { Sol. Al } \\
\text { (M) }\end{array}$} & \multirow{2}{*}{$\begin{array}{c}\text { Base } \\
\text { Saturation }\end{array}$} & \multirow{2}{*}{$\begin{array}{l}\text { BC:AI } \\
\text { Ratio }\end{array}$} & Acid In & Acid Out & Weathering & Protonat. & Bases Lost & Exch. Bases & Soil \\
\hline & & & & & \multicolumn{6}{|c|}{$\left(\mathrm{kmol} \mathrm{ha}^{-1} \mathrm{yr}^{-1}\right)$} & \\
\hline 0 & 5.4 & 2.84E-05 & 0.57 & 21 & 1.0 & 0.1 & $0.00 E+00$ & $0.00 E+00$ & 0.0 & 225.8 & Redwater Plain \\
\hline 1 & 5.4 & $2.84 \mathrm{E}-05$ & 0.57 & 21 & 1.0 & 0.1 & $0.00 E+00$ & $0.00 E+00$ & 0.9 & 224.9 & Redwater Plain \\
\hline 2 & 5.4 & 2.77E-05 & 0.57 & 21 & 1.0 & 0.1 & $1.59 E-04$ & 5.27E-04 & 0.9 & 223.9 & Redwater Plain \\
\hline 3 & 5.4 & 2.71E-05 & 0.57 & 21 & 1.0 & 0.1 & $3.18 \mathrm{E}-04$ & $1.05 \mathrm{E}-03$ & 0.9 & 223.0 & Redwater Plain \\
\hline
\end{tabular}




\subsubsection{Model Output}

The ARC model predictions of critical loads for critical chemical values reached after 50 and 100 years of acid deposition were derived from tabulated model output data for a 300 year period, and are presented in Table 14. Table 14 shows the changes in relation to given acid deposition inputs for four time periods. An example of model outputs is also presented in diagrammatic form in the charts in Figure 3.

Table 14. Changes in Soil Chemistry in Relation to Different Acid Inputs

\begin{tabular}{|c|c|c|c|c|c|c|c|c|c|c|c|c|}
\hline \multirow{2}{*}{\begin{tabular}{|c|} 
Acid Input \\
$\mathrm{kmol} \mathrm{ha}^{-1} \mathrm{yr}^{-1}$ \\
\end{tabular}} & \multicolumn{4}{|c|}{$\mathrm{pH}$} & \multicolumn{4}{|c|}{ Base Saturation } & \multicolumn{4}{|c|}{ BC:Al Ratio } \\
\hline & $0 \mathrm{yr}$ & $50 \mathrm{yr}$ & $100 \mathrm{yr}$ & $300 \mathrm{yr}$ & $0 \mathrm{yr}$ & $50 \mathrm{yr}$ & $100 \mathrm{yr}$ & $300 \mathrm{yr}$ & $0 \mathrm{yr}$ & $50 \mathrm{yr}$ & $100 \mathrm{yr}$ & $300 \mathrm{yr}$ \\
\hline \multicolumn{13}{|c|}{ Yeoford Plain/Falun Plain - Breton } \\
\hline 0.1 & 5.7 & 5.7 & 5.7 & 5.7 & 0.56 & 0.56 & 0.56 & 0.56 & 29 & 29 & 29 & 29 \\
\hline 0.2 & 5.7 & 5.7 & 5.7 & 5.7 & 0.56 & 0.56 & 0.56 & 0.56 & 29 & 29 & 29 & 29 \\
\hline 0.3 & 5.7 & 5.7 & 5.7 & 5.7 & 0.56 & 0.56 & 0.56 & 0.56 & 29 & 29 & 29 & 29 \\
\hline 0.5 & 5.7 & 5.7 & 5.7 & 5.7 & 0.56 & 0.56 & 0.56 & 0.56 & 29 & 29 & 29 & 29 \\
\hline 0.7 & 5.7 & 5.7 & 5.7 & 5.6 & 0.56 & 0.56 & 0.56 & 0.53 & 29 & 29 & 29 & 27 \\
\hline 1.0 & 5.7 & 5.7 & 5.6 & 5.4 & 0.56 & 0.56 & 0.53 & 0.44 & 29 & 29 & 27 & 24 \\
\hline \multicolumn{13}{|c|}{ Graminia Plain 1 - Nestow } \\
\hline 0.1 & 5.7 & 5.7 & 5.7 & 5.7 & 0.61 & 0.61 & 0.61 & 0.61 & 29 & 29 & 29 & 29 \\
\hline 0.2 & 5.7 & 5.7 & 5.7 & 5.7 & 0.61 & 0.61 & 0.61 & 0.61 & 29 & 29 & 29 & 29 \\
\hline 0.3 & 5.7 & 5.7 & 5.7 & 5.7 & 0.61 & 0.61 & 0.61 & 0.61 & 29 & 29 & 29 & 29 \\
\hline 0.5 & 5.7 & 5.7 & 5.7 & 5.6 & 0.61 & 0.61 & 0.60 & 0.54 & 29 & 29 & 28 & 25 \\
\hline 0.7 & 5.7 & 5.7 & 5.6 & 5.3 & 0.61 & 0.61 & 0.56 & 0.41 & 29 & 29 & 26 & 18 \\
\hline 1.0 & 5.7 & 5.7 & 5.4 & 4.9 & 0.61 & 0.61 & 0.49 & 0.21 & 29 & 29 & 22 & 11 \\
\hline \multicolumn{13}{|c|}{ Graminia Plain 2 - Helliwell } \\
\hline 0.1 & 6.4 & 6.4 & 6.4 & 6.4 & 0.77 & 0.77 & 0.77 & 0.77 & 65 & 65 & 65 & 65 \\
\hline 0.2 & 6.4 & 6.4 & 6.4 & 6.4 & 0.77 & 0.77 & 0.77 & 0.77 & 65 & 65 & 65 & 65 \\
\hline 0.3 & 6.4 & 6.4 & 6.4 & 6.4 & 0.77 & 0.77 & 0.77 & 0.77 & 65 & 65 & 65 & 65 \\
\hline 0.5 & 6.4 & 6.4 & 6.4 & 6.4 & 0.77 & 0.77 & 0.77 & 0.77 & 65 & 65 & 65 & 65 \\
\hline 0.7 & 6.4 & 6.4 & 6.4 & 6.4 & 0.77 & 0.77 & 0.77 & 0.77 & 65 & 65 & 65 & 65 \\
\hline 1.0 & 6.4 & 6.4 & 6.4 & 6.4 & 0.77 & 0.77 & 0.77 & 0.77 & 65 & 65 & 65 & 65 \\
\hline \multicolumn{13}{|c|}{ George Lake Plain 1 - Cooking Lake } \\
\hline 0.1 & 4.6 & 4.6 & 4.6 & 4.6 & 0.19 & 0.19 & 0.19 & 0.19 & 8 & 8 & 8 & 8 \\
\hline 0.2 & 4.6 & 4.6 & 4.6 & 4.6 & 0.19 & 0.19 & 0.19 & 0.19 & 8 & 8 & 8 & 8 \\
\hline 0.3 & 4.6 & 4.6 & 4.6 & 4.6 & 0.19 & 0.19 & 0.19 & 0.19 & 8 & 8 & 8 & 8 \\
\hline 0.5 & 4.6 & 4.6 & 4.6 & 4.6 & 0.19 & 0.19 & 0.19 & 0.19 & 8 & 8 & 8 & 8 \\
\hline 0.7 & 4.6 & 4.6 & 4.6 & 4.6 & 0.19 & 0.19 & 0.19 & 0.19 & 8 & 8 & 8 & 8 \\
\hline 1.0 & 4.6 & 4.6 & 4.6 & 4.6 & 0.19 & 0.19 & 0.19 & 0.19 & 8 & 8 & 8 & 8 \\
\hline \multicolumn{13}{|c|}{ Islet Upland 1 - Uncas } \\
\hline 0.1 & 4.6 & 4.6 & 4.6 & 4.6 & 0.42 & 0.42 & 0.42 & 0.42 & 8 & 8 & 8 & 8 \\
\hline 0.2 & 4.6 & 4.6 & 4.6 & 4.6 & 0.42 & 0.42 & 0.42 & 0.42 & 8 & 8 & 8 & 8 \\
\hline 0.3 & 4.6 & 4.6 & 4.6 & 4.6 & 0.42 & 0.42 & 0.42 & 0.42 & 8 & 8 & 8 & 8 \\
\hline 0.5 & 4.6 & 4.6 & 4.6 & 4.6 & 0.42 & 0.42 & 0.42 & 0.42 & 8 & 8 & 8 & 8 \\
\hline 0.7 & 4.6 & 4.6 & 4.6 & 4.6 & 0.42 & 0.42 & 0.42 & 0.42 & 8 & 8 & 8 & 8 \\
\hline 1.0 & 4.6 & 4.6 & 4.5 & 4.5 & 0.42 & 0.42 & 0.41 & 0.39 & 8 & 8 & 8 & 7 \\
\hline \multicolumn{13}{|c|}{ Islet Upland 2 - Cooking Lake } \\
\hline 0.1 & 5.4 & 5.4 & 5.4 & 5.4 & 0.57 & 0.57 & 0.57 & 0.57 & 21 & 21 & 21 & 21 \\
\hline 0.2 & 5.4 & 5.4 & 5.4 & 5.4 & 0.57 & 0.57 & 0.57 & 0.57 & 21 & 21 & 21 & 21 \\
\hline 0.3 & 5.4 & 5.4 & 5.4 & 5.4 & 0.57 & 0.57 & 0.57 & 0.57 & 21 & 21 & 21 & 21 \\
\hline 0.5 & 5.4 & 5.4 & 5.4 & 5.4 & 0.57 & 0.57 & 0.57 & 0.57 & 21 & 21 & 21 & 21 \\
\hline 0.7 & 5.4 & 5.4 & 5.4 & 5.4 & 0.57 & 0.57 & 0.57 & 0.57 & 21 & 21 & 21 & 21 \\
\hline
\end{tabular}


Table 14. Changes in Soil Chemistry in Relation to Different Acid Inputs

\begin{tabular}{|c|c|c|c|c|c|c|c|c|c|c|c|c|}
\hline \multirow{2}{*}{\begin{tabular}{|c|} 
Acid Input \\
$\mathrm{kmol} \mathrm{ha}^{-1} \mathrm{yr}^{-1}$
\end{tabular}} & \multicolumn{4}{|c|}{ pH } & \multicolumn{4}{|c|}{ Base Saturation } & \multicolumn{4}{|c|}{ BC:Al Ratio } \\
\hline & $0 \mathrm{yr}$ & $50 \mathrm{yr}$ & $100 \mathrm{yr}$ & $300 \mathrm{yr}$ & $0 \mathrm{yr}$ & $50 \mathrm{yr}$ & $100 \mathrm{yr}$ & $300 \mathrm{yr}$ & $0 \mathrm{yr}$ & $50 \mathrm{yr}$ & $100 \mathrm{yr}$ & $300 \mathrm{yr}$ \\
\hline 1.0 & 5.4 & 5.4 & 5.4 & 5.2 & 0.57 & 0.57 & 0.57 & 0.49 & 21 & 21 & 21 & 17 \\
\hline \multicolumn{13}{|c|}{ George Lake Plain 2 - Cooking Lake } \\
\hline 0.1 & 5.7 & 5.7 & 5.7 & 5.7 & 0.55 & 0.55 & 0.55 & 0.55 & 29 & 29 & 29 & 29 \\
\hline 0.2 & 5.7 & 5.7 & 5.7 & 5.7 & 0.55 & 0.55 & 0.55 & 0.55 & 29 & 29 & 29 & 29 \\
\hline 0.3 & 5.7 & 5.7 & 5.7 & 5.7 & 0.55 & 0.55 & 0.55 & 0.55 & 29 & 29 & 29 & 29 \\
\hline 0.5 & 5.7 & 5.7 & 5.7 & 5.7 & 0.55 & 0.55 & 0.55 & 0.55 & 29 & 29 & 29 & 29 \\
\hline 0.7 & 5.7 & 5.7 & 5.7 & 5.7 & 0.55 & 0.55 & 0.55 & 0.55 & 29 & 29 & 29 & 29 \\
\hline 1.0 & 5.7 & 5.7 & 5.7 & 5.7 & 0.55 & 0.55 & 0.55 & 0.54 & 29 & 29 & 29 & 29 \\
\hline \multicolumn{13}{|c|}{ George Lake Plain 3 - Cooking Lake (Acidic) } \\
\hline 0.1 & 4.4 & 4.4 & 4.4 & 4.4 & 0.20 & 0.20 & 0.20 & 0.20 & 7 & 7 & 7 & 7 \\
\hline 0.2 & 4.4 & 4.4 & 4.4 & 4.4 & 0.20 & 0.20 & 0.20 & 0.20 & 7 & 7 & 7 & 7 \\
\hline 0.3 & 4.4 & 4.4 & 4.4 & 4.4 & 0.20 & 0.20 & 0.20 & 0.20 & 7 & 7 & 7 & 7 \\
\hline 0.5 & 4.4 & 4.4 & 4.4 & 4.4 & 0.20 & 0.20 & 0.20 & 0.20 & 7 & 7 & 7 & 7 \\
\hline 0.7 & 4.4 & 4.4 & 4.4 & 4.4 & 0.20 & 0.20 & 0.20 & 0.20 & 7 & 7 & 7 & 7 \\
\hline 1.0 & 4.4 & 4.4 & 4.4 & 4.4 & 0.20 & 0.20 & 0.20 & 0.20 & 7 & 7 & 7 & 7 \\
\hline \multicolumn{13}{|c|}{ George Lake Plain 4 - Cooking Lake (Forage) } \\
\hline 0.1 & 4.8 & 4.8 & 4.8 & 4.8 & 0.29 & 0.29 & 0.29 & 0.29 & 10 & 10 & 10 & 10 \\
\hline 0.2 & 4.8 & 4.8 & 4.8 & 4.8 & 0.29 & 0.29 & 0.29 & 0.29 & 10 & 10 & 10 & 10 \\
\hline 0.3 & 4.8 & 4.8 & 4.8 & 4.8 & 0.29 & 0.29 & 0.29 & 0.29 & 10 & 10 & 10 & 10 \\
\hline 0.5 & 4.8 & 4.8 & 4.8 & 4.8 & 0.29 & 0.29 & 0.28 & 0.29 & 10 & 10 & 10 & 10 \\
\hline 0.7 & 4.8 & 4.8 & 4.7 & 4.5 & 0.29 & 0.27 & 0.25 & 0.17 & 10 & 10 & 9 & 7 \\
\hline 1.0 & 4.8 & 4.7 & 4.6 & 4.3 & 0.29 & 0.25 & 0.21 & 0.05 & 10 & 9 & 8 & 6 \\
\hline \multicolumn{13}{|c|}{ Islet Upland 3 - Cooking Lake (Forage) } \\
\hline 0.1 & 6.3 & 6.3 & 6.2 & 6.2 & 0.63 & 0.63 & 0.62 & 0.60 & 55 & 54 & 53 & 51 \\
\hline 0.2 & 6.3 & 6.2 & 6.2 & 6.1 & 0.63 & 0.62 & 0.61 & 0.57 & 55 & 53 & 51 & 46 \\
\hline 0.3 & 6.3 & 6.2 & 6.2 & 6.0 & 0.63 & 0.61 & 0.59 & 0.53 & 55 & 52 & 49 & 42 \\
\hline 0.5 & 6.3 & 6.2 & 6.1 & 5.9 & 0.63 & 0.60 & 0.56 & 0.46 & 55 & 50 & 46 & 35 \\
\hline 0.7 & 6.3 & 6.2 & 6.1 & 5.7 & 0.63 & 0.58 & 0.54 & 0.39 & 55 & 48 & 43 & 29 \\
\hline 1.0 & 6.3 & 6.1 & 6.0 & 5.5 & 0.63 & 0.56 & 0.50 & 0.27 & 55 & 46 & 39 & 22 \\
\hline \multicolumn{13}{|c|}{ Pipestone Upland 1 - Helliwell } \\
\hline 0.1 & 5.2 & 5.2 & 5.2 & 5.2 & 0.52 & 0.52 & 0.52 & 0.52 & 16 & 16 & 16 & 16 \\
\hline 0.2 & 5.2 & 5.2 & 5.2 & 5.2 & 0.52 & 0.52 & 0.52 & 0.52 & 16 & 16 & 16 & 16 \\
\hline 0.3 & 5.2 & 5.2 & 5.2 & 5.2 & 0.52 & 0.52 & 0.52 & 0.51 & 16 & 16 & 16 & 16 \\
\hline 0.5 & 5.2 & 5.2 & 5.1 & 4.9 & 0.52 & 0.51 & 0.49 & 0.43 & 16 & 16 & 14 & 11 \\
\hline 0.7 & 5.2 & 5.1 & 5.0 & 4.7 & 0.52 & 0.49 & 0.45 & 0.37 & 16 & 15 & 13 & 9 \\
\hline 1.0 & 5.2 & 5.0 & 4.8 & 4.6 & 0.52 & 0.46 & 0.40 & 0.33 & 16 & 13 & 10 & 8 \\
\hline \multicolumn{13}{|c|}{ Pipestone Upland 2 - Peace Hills } \\
\hline 0.1 & 5.6 & 5.6 & 5.6 & 5.5 & 0.57 & 0.57 & 0.56 & 0.55 & 25 & 25 & 25 & 24 \\
\hline 0.2 & 5.6 & 5.6 & 5.5 & 5.4 & 0.57 & 0.56 & 0.55 & 0.52 & 25 & 25 & 24 & 21 \\
\hline 0.3 & 5.6 & 5.6 & 5.5 & 5.4 & 0.57 & 0.56 & 0.54 & 0.50 & 25 & 24 & 23 & 19 \\
\hline 0.5 & 5.6 & 5.4 & 5.4 & 5.2 & 0.57 & 0.55 & 0.52 & 0.44 & 25 & 23 & 21 & 16 \\
\hline 0.7 & 5.6 & 5.5 & 5.4 & 5.0 & 0.57 & 0.54 & 0.51 & 0.39 & 25 & 23 & 20 & 13 \\
\hline 1.0 & 5.6 & 5.4 & 5.3 & 4.7 & 0.57 & 0.52 & 0.48 & 0.30 & 25 & 21 & 18 & 9 \\
\hline \multicolumn{13}{|c|}{ Redwater Plain/Halfway Lake Dunefield - Nestow } \\
\hline 0.1 & 5.1 & 5.1 & 5.0 & 5.0 & 0.44 & 0.41 & 0.38 & 0.34 & 15 & 14 & 14 & 12 \\
\hline 0.2 & 5.1 & 5.1 & 5.0 & 4.9 & 0.44 & 0.40 & 0.37 & 0.33 & 15 & 14 & 13 & 12 \\
\hline 0.3 & 5.1 & 5.0 & 4.9 & 4.8 & 0.44 & 0.38 & 0.33 & 0.28 & 15 & 13 & 12 & 11 \\
\hline 0.5 & 5.1 & 4.9 & 4.7 & 4.7 & 0.44 & 0.31 & 0.25 & 0.22 & 15 & 12 & 10 & 9 \\
\hline 0.7 & 5.1 & 4.7 & 4.6 & 4.6 & 0.44 & 0.24 & 0.18 & 0.17 & 15 & 10 & 8 & 8 \\
\hline
\end{tabular}


Table 14. Changes in Soil Chemistry in Relation to Different Acid Inputs

\begin{tabular}{|c|c|c|c|c|c|c|c|c|c|c|c|c|}
\hline \multirow{2}{*}{$\begin{array}{c}\text { Acid Input } \\
\mathrm{kmol} \mathrm{ha}^{-1} \mathrm{yr}^{-1}\end{array}$} & \multicolumn{4}{|c|}{$\mathrm{pH}$} & \multicolumn{4}{|c|}{ Base Saturation } & \multicolumn{4}{|c|}{ BC:Al Ratio } \\
\hline & O yr & $50 \mathrm{yr}$ & $100 \mathrm{yr}$ & $300 \mathrm{yr}$ & $0 \mathrm{yr}$ & $50 \mathrm{yr}$ & $100 \mathrm{yr}$ & $300 \mathrm{yr}$ & $0 \mathrm{yr}$ & $50 \mathrm{yr}$ & $100 \mathrm{yr}$ & $300 \mathrm{yr}$ \\
\hline 1.0 & 5.1 & 4.6 & 4.5 & 4.5 & 0.44 & 0.18 & 0.14 & 0.14 & 15 & 8 & 8 & 8 \\
\hline \multicolumn{13}{|c|}{ Redwater Plain - Nestow (Forage) } \\
\hline 0.1 & 5.4 & 5.4 & 5.4 & 5.4 & 0.57 & 0.57 & 0.56 & 0.54 & 21 & 21 & 20 & 19 \\
\hline 0.2 & 5.4 & 5.4 & 5.3 & 5.2 & 0.57 & 0.56 & 0.54 & 0.47 & 21 & 20 & 19 & 16 \\
\hline 0.3 & 5.4 & 5.4 & 5.3 & 5.0 & 0.57 & 0.54 & 0.51 & 3.9 & 21 & 19 & 18 & 14 \\
\hline 0.5 & 5.4 & 5.3 & 5.2 & 4.8 & 0.57 & 0.52 & 0.46 & 0.25 & 21 & 18 & 16 & 10 \\
\hline 0.7 & 5.4 & 5.3 & 5.1 & 4.5 & 0.57 & 0.49 & 0.41 & 0.11 & 21 & 17 & 14 & 7 \\
\hline 1.0 & 5.4 & 5.2 & 4.9 & 4.2 & 0.57 & 0.45 & 0.34 & 0.00 & 21 & 16 & 12 & 5 \\
\hline
\end{tabular}



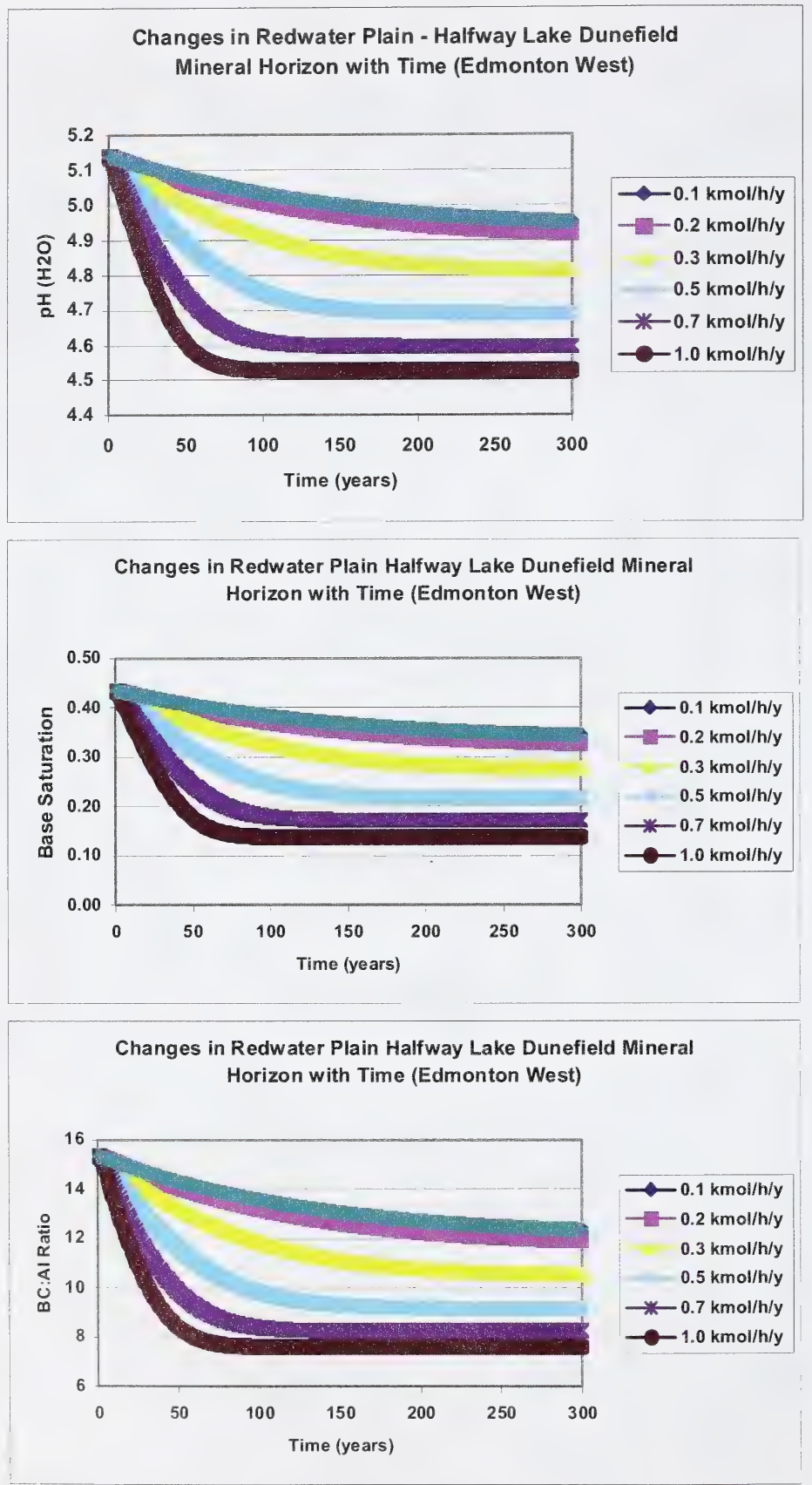

Figure 3. Example of Soil Chemistry Changes Over Time 


\subsubsection{Critical Chemical Values for the Soil Groups}

The rationale for selecting critical chemical values was described in Section 2.2. In order to derive critical loads, the threshold level for a change in a chemical parameter must be selected, as well as the period over which this change can occur. Once a threshold is reached, however, soil chemistry would be negatively affected. A level of protection of the soil was considered whereby only a percentage of a parameter in question would be affected, well before the critical load is reached. This approach was applied in developing critical loads in the Oil Sands area, upon the suggestion of the $\mathrm{NO} \times / \mathrm{SO}_{2}$ Management Working Group of the Cumulative Environmental Management Association (Abboud et al. 2002). Levels of $75 \%$ of the original soil value, and the mid-point between the original value and the literature-based critical load, were examined. The more protective of these levels is recommended in the examination of critical loads for the Edmonton West grid cell, namely application of the $75 \%$ case as the soil critical load. Acidification (i.e., PAI) levels resulting in these thresholds being reached within 50 and 100 years were derived from the model data. The lower value of the BC:Al ratio or base saturation percentage is suggested as the critical load. PAI levels required to reach the full critical chemical values were also examined, including the critical values of $\mathrm{pH}\left(\mathrm{H}_{2} \mathrm{O}\right) 4.0$ and 5.6, for forested and grassland soils respectively. Table 15 shows the critical chemical values established or calculated for the various soil groups.

Table 15. Critical Chemical Values Calculated from Initial Soil Data

\begin{tabular}{|c|c|c|c|c|c|c|c|c|c|}
\hline \multirow[t]{2}{*}{ Site } & \multirow[t]{2}{*}{ Soil Series } & \multicolumn{8}{|c|}{ Mineral Critical Chemical Value } \\
\hline & & $\mathrm{pH}_{\mathrm{hi}}{ }^{\mathrm{Y}}$ & $\begin{array}{c}\mathrm{pH}_{\mathrm{h}}= \\
4.0 \text { or } 5.6\end{array}$ & BSat $_{i}$ & $\begin{array}{l}\text { BSat }_{i} \\
75 \%\end{array}$ & BSat $=0.1$ & BC: $\mathrm{Al}_{i}$ & $\begin{array}{c}\mathrm{BC}: \mathrm{Al}_{1} \\
75 \%\end{array}$ & $\begin{array}{c}\mathrm{BC}: \mathrm{Al}=1 \\
\text { or } 45\end{array}$ \\
\hline \multicolumn{10}{|l|}{ Luvisols } \\
\hline $\begin{array}{l}\text { Yeoford Plain/Falun } \\
\text { Plain }\end{array}$ & Breton & 5.7 & 4.0 & 0.56 & 0.42 & 0.1 & 29 & 22 & 1 \\
\hline George Lake Plain 1 & Cooking Lake & 46 & 4.0 & 0.19 & 0.14 & 0.1 & 8 & 6 & 1 \\
\hline Islet Upland 1 & Uncas & 4.6 & 4.0 & 0.42 & 0.32 & 0.1 & 8 & 6 & 1 \\
\hline Islet Upland 2 & Cooking Lake & 5.4 & 4.0 & 0.57 & 0.43 & 0.1 & 21 & 16 & 1 \\
\hline George Lake Plain 2 & Cooking Lake & 5.7 & 4.0 & 0.55 & 0.41 & 0.1 & 29 & 22 & 1 \\
\hline George Lake Plain 3 & Cooking Lake (Acidic) & 4.4 & 4.0 & 0.20 & 0.15 & 0.1 & 7 & 5 & 1 \\
\hline George Lake Plain 4 & Cooking Lake (Forage) & 4.8 & 4.0 & 0.29 & 0.22 & 0.1 & 10 & 8 & 1 \\
\hline Islet Upland 3 & Cooking Lake (Forage) & 6.3 & 4.0 & 0.63 & 0.47 & 0.1 & 58 & 44 & 1 \\
\hline \multicolumn{10}{|l|}{ Brunisols } \\
\hline Graminia Plain 1 & Nestow & 5.7 & 4.0 & 0.61 & 0.46 & 0.1 & 16 & 12 & 1 \\
\hline $\begin{array}{l}\text { Redwater Plain/ } \\
\text { Halfway Lake Dunefield }\end{array}$ & Nestow & 5.1 & 4.0 & 0.44 & 0.33 & 0.1 & 15 & 11 & 1 \\
\hline Redwater Plain & Nestow (Forage) & 5.4 & 4.0 & 0.57 & 0.43 & 0.1 & 21 & 16 & 1 \\
\hline \multicolumn{10}{|l|}{ Chernozems } \\
\hline Graminia Plain 2 & Helliwell & 6.4 & 5.6 & 0.77 & 0.58 & 0.1 & 65 & 49 & 45 \\
\hline Pipestone Upland 1 & Helliwell & 5.2 & 5.6 & 0.52 & 0.39 & 0.1 & 16 & 12 & 45 \\
\hline Pipestone Plain 2 & Peace Hills & 5.6 & 5.6 & 0.57 & 0.43 & 0.1 & 26 & 20 & 45 \\
\hline
\end{tabular}

Critical chemical value for the $25 \mathrm{~cm}$ surface soil layer.

$\checkmark$ Abbreviations: $\mathrm{pH}_{h}$ - soil $\mathrm{pH}$ measured in $\mathrm{H}_{2} \mathrm{O}$ solution; $\mathrm{pH}_{h i}$ - initial $\mathrm{pH}$; BSat - base saturation percentage; $\mathrm{Bsat}_{\mathrm{i}}$ - initial BSat; $B C: A l$ - base cation to aluminum ratio in soil solution; $B C: A l_{i}$ - initial $B C: A l$. 


\subsubsection{Critical Load Derivation}

The time frame within which changes in soil chemistry occur is an important consideration in using dynamic models to derive critical loads. Decisions are required as to whether critical values of soil chemical parameters may be reached in only a few years, or over a longer period. Fifty and one hundred year time periods were selected for these decisions. Fifty years is a relatively short period, and its selection is based on the view that it is of sufficient length to enable detection of an actual acidification trend and to initiate measures to counteract the trend. One hundred years is a longer time frame that results in a lower critical load, and it therefore provides a greater measure of protection.

The ARC model predictions of critical loads for critical chemical values reached after 50 and 100 years of acid deposition were derived from the tabulated model output (Table 14), and are presented in Table 16.

The lowest critical loads were obtained for the $75 \%$ case of the $\mathrm{BC}$ :Al ratio. Applying the principle of selecting the lowest of the calculated critical loads, the BC:Al ratio would therefore provide the basis of critical loads for soils in the study area. The highest critical loads were obtained for the Luvisolic and Chernozemic soils. Although the Chernozemic soils included in this investigation are very coarse to coarse textured, acid buffering is provided by the relatively high organic matter content which contributes a large supply of exchangeable cations in addition to that associated with the mineral component alone. Acid buffering in Luvisols is likely influenced by their finer textures as compared to the Brunisols and Chernozems. The Brunisols in the Edmonton West area have low organic matter and clay content, and they therefore have the least acid buffering capacity. 
Table 16. ARC Model Predictions of Critical Loads for Critical Chemical Values Reached after 50 and 100 Years of Acid Deposition

\begin{tabular}{|c|c|c|c|c|c|c|c|}
\hline \multirow{2}{*}{ Site } & \multirow{2}{*}{ Soil Series } & \multirow{2}{*}{$\begin{array}{c}\text { Time } \\
\text { (years) }\end{array}$} & \multicolumn{5}{|c|}{$\begin{array}{l}\text { Mineral Critical Load Value } \\
\left(\mathrm{kmol} \mathrm{H}^{+} \mathrm{ha}^{-1} \mathrm{yr}^{-1}\right)\end{array}$} \\
\hline & & & $\mathrm{pH}_{\mathrm{h}}{ }^{\gamma}$ & BSat $\times 0.75$ & $\begin{array}{c}\text { BSat }=0.1 \\
0.5\end{array}$ & $B C: A l_{i} \times 0.75$ & $\begin{array}{c}\mathrm{BC}: \mathrm{Al}=1 \\
\text { or } 45\end{array}$ \\
\hline \multicolumn{8}{|l|}{ Luvisols } \\
\hline \multirow[t]{2}{*}{$\begin{array}{l}\text { Yeoford Plain/ Falun } \\
\text { Plain }\end{array}$} & Breton & 50 & $>1$ & $>1$ & $>1$ & $>1$ & $>1$ \\
\hline & & 100 & $>1$ & $>1$ & $>1$ & $>1$ & $>1$ \\
\hline \multirow[t]{2}{*}{ George Lake Plain 1} & Cooking Lake & 50 & $>1$ & $>1$ & $>1$ & $>1$ & $>1$ \\
\hline & & 100 & $>1$ & $>1$ & $>1$ & $>1$ & $>1$ \\
\hline \multirow[t]{2}{*}{ Islet Upland 1} & Uncas & 50 & $>1$ & $>1$ & $>1$ & $>1$ & $>1$ \\
\hline & & 100 & $>1$ & $>1$ & $>1$ & $>1$ & $>1$ \\
\hline \multirow[t]{2}{*}{ Islet Upland 2} & Cooking Lake & 50 & $>1$ & $>1$ & $>1$ & $>1$ & $>1$ \\
\hline & & 100 & $>1$ & $>1$ & $>1$ & $>1$ & $>1$ \\
\hline \multirow[t]{2}{*}{ George Lake Plain 2} & Cooking Lake & 50 & $>1$ & $>1$ & $>1$ & $>1$ & $>1$ \\
\hline & & 100 & $>1$ & $>1$ & $>1$ & $>1$ & $>1$ \\
\hline \multirow[t]{2}{*}{ George Lake Plain 3} & Cooking Lake (Acidic) & 50 & $>1$ & $>1$ & $>1$ & $>1$ & $>1$ \\
\hline & & 100 & $>1$ & $>1$ & $>1$ & $>1$ & $>1$ \\
\hline \multirow[t]{2}{*}{ George Lake Plain 4} & Cooking Lake (Forage) & 50 & $>1$ & $>1$ & $>1$ & $>1$ & $>1$ \\
\hline & & 100 & $>1$ & $>1$ & $>1$ & $>1$ & $>1$ \\
\hline \multirow[t]{2}{*}{ Islet Upland 3} & Cooking Lake (Forage) & 50 & $>1$ & $>1$ & $>1$ & $>1$ & $>1$ \\
\hline & & 100 & $>1$ & $>1$ & $>1$ & 0.8 & $>1$ \\
\hline \multicolumn{8}{|l|}{ Brunisols } \\
\hline \multirow[t]{2}{*}{ Graminia Plain 1} & Nestow & 50 & $>1$ & $>1$ & $>1$ & $>1$ & $>1$ \\
\hline & & 100 & $>1$ & $>1$ & $>1$ & $>1$ & $>1$ \\
\hline \multirow[t]{2}{*}{$\begin{array}{l}\text { Redwater Plain/Halfway } \\
\text { Lake Dunefield }\end{array}$} & Nestow & 50 & $>1$ & 0.7 & $>1$ & 0.7 & $>1$ \\
\hline & & 100 & $>1$ & 0.6 & $>1$ & 0.5 & $>1$ \\
\hline \multirow[t]{2}{*}{ Redwater Plain } & Nestow (Forage) & 50 & $>1$ & $>1$ & $>1$ & 1 & $>1$ \\
\hline & & 100 & $>1$ & 0.8 & $>1$ & 0.7 & $>1$ \\
\hline \multicolumn{8}{|l|}{ Chernozems } \\
\hline \multirow[t]{2}{*}{ Graminia Plain 2} & Helliwell & 50 & $>1$ & $>1$ & $>1$ & $>1$ & $>1^{V}$ \\
\hline & & 100 & $>1$ & $>1$ & $>1$ & $>1$ & $>1^{v}$ \\
\hline \multirow[t]{2}{*}{ Pipestone Upland 1} & Helliwell & 50 & $-x$ & $>1$ & $>1$ & $>1^{w}$ & $>1^{V}$ \\
\hline & & 100 & $-x$ & $>1$ & $>1$ & $0.8^{w}$ & $>1^{V}$ \\
\hline \multirow[t]{2}{*}{ Pipestone Upland 2} & Peace Hills & 50 & $-x$ & $>1$ & $>1$ & $>1^{w}$ & $>1^{V}$ \\
\hline & & 100 & $-x$ & $>1$ & $>1$ & $0.8^{w}$ & $>1^{V}$ \\
\hline
\end{tabular}

Symbols: BSat - base saturation; $\mathrm{BC}: \mathrm{Al}$ - base cation to Al ratio; $\mathrm{i}$ - the initial, or model input value; $75 \%$ percentage of the initial value.

${ }^{\mathrm{P}} \mathrm{pH}_{\mathrm{h}}$ values are 4.0 for Luvisols and Brunisols, and 5.6 for Chernozems; $\mathrm{BC}$ :Al critical values are 1 for Luvisols and Brunisols, and 45 for Chernozems.

${ }^{x}$ Chernozemic soils with critical $\mathrm{pH}$ of 5.6 ; initial $\mathrm{pH}$ values of these soils were $<5.6$.

${ }^{w}$ Critical load based on $75 \%$ reduction of $\mathrm{BC}: \mathrm{Al}$ ratio. However, the initial values are less than the $\mathrm{BC}: \mathrm{Al}$ critical chemical value of 45 for Chernozemic soils.

$\checkmark$ Chernozemic soils with BC:AI CCV of 45. All other soils have BC:AI CCV of 1. 


\subsection{COMPARISON OF METHODS OF CRITICAL LOAD DERIVATION}

Critical loads for sandy soils in the Edmonton West study area, as determined by the Empirical, Steady State Mass Balance and ARC models are summarized in Table 17.

Table 17. Comparison of Critical Loads Derived by Different Methods

\begin{tabular}{|c|c|c|c|c|c|c|c|}
\hline $\begin{array}{l}\text { CL Derivation } \\
\text { Method and }\end{array}$ & & & & $\begin{array}{l}\text { Critical Load } \\
\left(\mathrm{kmol} \mathrm{ha}^{-1} \mathrm{yr}^{-}\right.\end{array}$ & & & \\
\hline Land System & $\begin{array}{c}\text { Yeoford/ } \\
\text { Falun Plain }\end{array}$ & $\begin{array}{l}\text { Graminia } \\
\text { Plain } 1 \\
\end{array}$ & $\begin{array}{l}\text { Graminia } \\
\text { Plain } 2 \\
\end{array}$ & \begin{tabular}{|c|} 
George \\
Lake Plain 1 \\
\end{tabular} & $\begin{array}{c}\text { Islet } \\
\text { Upland } 1 \\
\end{array}$ & $\begin{array}{c}\text { Islet } \\
\text { Upland } 2\end{array}$ & $\begin{array}{c}\text { George } \\
\text { Lake Plain } 2\end{array}$ \\
\hline Sites & $13,16,18$ & 17 & 11 & 12 & 19 & $\begin{array}{c}5,6,7, \\
8, \mathrm{BR}\end{array}$ & 3 \\
\hline Empirical & $1-2$ & $0.2-0.5$ & $0.5-1.0$ & $1-2$ & $1-2$ & $1-2$ & $1-2$ \\
\hline SSMB & 2.9 & 0.7 & 0.4 & 2.9 & 2.9 & 2.9 & 2.9 \\
\hline ARC $\mathrm{pH}_{50}$ & $>1$ & $>1$ & $>1$ & $>1$ & $>1$ & $>1$ & $>1$ \\
\hline ARC $\mathrm{pH}_{100}$ & $>1$ & $>1$ & $>1$ & $>1$ & $>1$ & $>1$ & $>1$ \\
\hline ARC BSat $_{50}$ & $>1$ & $>1$ & $>1$ & $>1$ & $>1$ & $>1$ & $>1$ \\
\hline ARC BSat $_{100}$ & $>1$ & $>1$ & $>1$ & $>1$ & $>1$ & $>1$ & $>1$ \\
\hline ARC BC: $\mathrm{Al}_{50}$ & $>1$ & $>1$ & $>1$ & $>1$ & $>1$ & $>1$ & $>1$ \\
\hline ARC BC:Al 100 & $>1$ & $>1$ & $>1$ & $>1$ & $>1$ & $>1$ & $>1$ \\
\hline Land System & $\begin{array}{c}\text { George } \\
\text { Lake Plain } 3\end{array}$ & $\begin{array}{c}\text { George } \\
\text { Lake Plain } 4\end{array}$ & $\begin{array}{c}\text { Islet } \\
\text { Upland } 3\end{array}$ & $\begin{array}{l}\text { Pipestone } \\
\text { Upland } 1\end{array}$ & $\begin{array}{l}\text { Pipestone } \\
\text { Upland } 2\end{array}$ & $\begin{array}{c}\text { Redwater } \\
\text { Plain/Halfway } \\
\text { Lake Dunefield }\end{array}$ & $\begin{array}{l}\text { Redwater } \\
\text { Plain }\end{array}$ \\
\hline Sites & 4 & 1 & 24 & 22 & 25 & $\begin{array}{l}9,10 \\
23,26\end{array}$ & 15 \\
\hline Empirical & $1-2$ & $1-2$ & $1-2$ & $0.5-1.0$ & $0.5-1.0$ & $0.2-0.5$ & $0.2-0.5$ \\
\hline SSMB & 2.9 & 2.9 & 2.9 & 0.4 & 0.5 & 0.6 & 0.6 \\
\hline ARC $\mathrm{pH}_{50}$ & $>1$ & $>1$ & $>1$ & -4 & $-z$ & $>1$ & $>1$ \\
\hline ARC $\mathrm{pH}_{100}$ & $>1$ & $>1$ & $>1$ & -2 & -2 & $>1$ & $>1$ \\
\hline ARC BSat 50 & $>1$ & $>1$ & $>1$ & $>1$ & $>1$ & 0.7 & $>1$ \\
\hline ARC BSat $_{100}$ & $>1$ & $>1$ & $>1$ & $>1$ & $>1$ & 0.6 & 0.8 \\
\hline ARC BC:Al 50 & $>1$ & $>1$ & $>1$ & $>1$ & $>1$ & 0.7 & 1 \\
\hline ARC BC:Al 100 & $>1$ & $>1$ & 0.8 & 0.8 & 0.8 & 0.5 & 0.7 \\
\hline
\end{tabular}

Chernozemic soils with critical $\mathrm{pH}$ of 5.6 ; initial $\mathrm{pH}$ values of these soils were $<5.6$.

The highest critical loads were obtained with the Empirical and the SSMB approaches for the medium to moderately fine textured Luvisolic soils typical of the George Lake Plain and the Islet Upland land systems. Critical loads based on the ARC model were generally greater than 1 $\mathrm{kmol} \mathrm{ha}^{-1} \mathrm{yr}^{-1}$, which is in general agreement with the Empirical and SSMB results.

Moderately coarse textured soils of the Graminia Upland and the Pipestone Upland had critical loads in the range of $0.5-1.0 \mathrm{kmol} \mathrm{ha}^{-1} \mathrm{yr}^{-1}$ based on the Empirical and SSMB models, but the loads were mainly $>1 \mathrm{kmol} \mathrm{ha}^{-1} \mathrm{yr}^{-1}$ based on the ARC model. The soil in Graminia Plain 1 was coarser textured than that of Graminia Plain 2, and had a comparatively lower critical load. For this soil, the ARC load was also $>1 \mathrm{kmol} \mathrm{ha}^{-1} \mathrm{yr}^{-1}$. The differences between the ARC model results and the Empirical and SSMB results are attributed to the buffering provided by organic matter in these soils, which is included in the ARC model but not in the other approaches. That 
is, since the critical loads determined with the ARC model are based on cation exchange buffering, the influence of both organic matter and mineral exchangeable ions is included.

The lowest critical loads were derived for the Nestow soils of the Redwater Plain and the Halfway Lake Dunefield. The critical load is $0.5 \mathrm{kmol} \mathrm{ha}^{-1} \mathrm{yr}^{-1}$ based on the ARC model, 0.2-0.5 $\mathrm{kmol} \mathrm{ha}^{-1} \mathrm{yr}^{-1}$ based on the Empirical approach, and $0.6 \mathrm{kmol} \mathrm{ha}^{-1} \mathrm{yr}^{-1}$ based on the SSMB approach. Redwater Plain 2 is also characterized by the Nestow soil series, but it is a cultivated soil with forage cover, and it has a slightly higher critical load than the undisturbed Nestow soils.

With respect to critical chemical criteria, the lowest critical loads were obtained for the $B C: A L_{100}$ ratio. Critical loads according to the ARC BC:AL 50 criterion were commonly similar to those of the Empirical approach, while the SSMB CLs were consistently higher than both of these. However, the SSMB CLs were generally lower than those based on the ARC pH criteria.

Both the Empirical and SSMB approaches to setting critical loads are based on maintaining steady-state over a very long time. They are based on replenishment of base cations in soil by weathering. Steady state methods represent the worst case, and cannot provide a basis for establishment of target loads, which need to be defined in terms of a timescale within which an ecosystem will not be affected (Jenkins et al. 2003). A considerable amount of buffering capability is provided by cations on the cation exchange complex. For protection of soils in the relatively short term, simulation of soil chemistry by dynamic modelling based on cation exchange buffering, as well as weathering, provides more relevant predictions than methods based on weathering alone. 


\section{1}

SENSITIVITY CLASSES

Previous sections of this report have focused on deriving the critical load for individual soil profiles or groups of very similar profiles. The profiles for which critical loads were derived in this study can be considered to be representative of the various soil series examined. For mapping purposes, however, the critical loads were considered in terms of sensitivity classes by applying an approach developed for the Provost-Esther critical loads study (Abboud et al., 2002). The approach uses both 50 and 100 year model results, and links the critical load determinations to sensitivity classes and to mapping of the loads.

The critical loads were assigned to a sensitivity class that could more or less be equated with critical loads for application in Alberta (Clean Air Strategic Alliance and Alberta Environment 1999). These critical loads are $0.25 \mathrm{kmol} \mathrm{ha}^{-1} \mathrm{yr}^{-1}$ for Sensitive soils, $0.50 \mathrm{kmol} \mathrm{ha}^{-1} \mathrm{yr}^{-1}$ for Moderately Sensitive soils, and $1.00 \mathrm{kmol} \mathrm{ha}^{-1} \mathrm{yr}^{-1}$ for Low Sensitivity soils. Turchenek and Abboud (2001) suggested critical load and sensitivity classes as follows:

$\leq 0.2 \mathrm{kmol} \mathrm{ha}^{-1} \mathrm{yr}^{-1}$; critical chemical value reached within 100 years

0.2 to $0.5 \mathrm{kmol} \mathrm{ha}^{-1} \mathrm{yr}^{-1}$; critical chemical value within 50 years

0.2 to $0.5 \mathrm{kmol} \mathrm{ha}^{-1} \mathrm{yr}^{-1}$; critical chemical value within 100 years

0.5 to $1.0 \mathrm{kmol} \mathrm{ha}^{-1} \mathrm{yr}^{-1}$; critical chemical value within 50 years

0.5 to $1.0 \mathrm{kmol} \mathrm{ha}^{-1} \mathrm{yr}^{-1}$; critical chemical value within 100 years

$>1.0 \mathrm{kmol} \mathrm{ha}^{-1} \mathrm{yr}^{-1}$; critical chemical value within 50 years
Sensitive

Sensitive

Moderate Sensitivity

Moderate Sensitivity

Low Sensitivity

Low Sensitivity

The lower value of base saturation or BC:Al critical loads obtained by modelling was used to determine the sensitivity category. The above categories of soil sensitivity indicate, for example, that if $\mathrm{BSat}$ or $\mathrm{BC}: \mathrm{Al}$ is reduced to $75 \%$ of the original value within 100 years at a Potential Acid Input level of $\leq 0.2 \mathrm{kmol} \mathrm{ha}^{-1} \mathrm{yr}^{-1}$, than the soil would be regarded as Sensitive. If 0.2 to $0.5 \mathrm{kmol}$ $\mathrm{ha}^{-1} \mathrm{yr}^{-1}$ reduces these soil properties to the critical chemical values within 50 years, then the soil would also be regarded as Sensitive. However, if 50 to 100 years is required at this latter level, than the soil would be allocated to the Moderate Sensitivity class.

This approach enables the allocation of a specific soil profile to a sensitivity class. The above criteria were applied to the eighteen representative soils or soil groups to which the ARC model was applied, and compared to acidification sensitivity criteria of Holowaychuk and Fessenden (1987). Results are presented in Table 18, along with Holowaychuk and Fessenden (H-F) ratings.

The H-F sensitivity rating in the above table is based directly on the sensitivity map of Holowaychuk and Fessenden (1987). On this map, the Islet Upland Land System (also known as the Cooking Lake moraine) and the North Saskatchewan River Valley were identified as having soils with potentially Moderate Sensitivity, and the Graminia Plain Land System was rated as having (High) Sensitive soils. The ARC modelling results suggest that the predominantly Luvisolic soils of the Islet Upland have Low Sensitivity to acidification. Other differences between the Holowaychuk-Fessenden mapping and the ARC model results pertain to the sandy Brunisolic soils of the Redwater Plain, Halfway Lake Dunefield and Eldorena Plain. 
These are mapped as having Low Sensitivity in the Holowaychuk-Fessenden map. In the current study, some of the soils that characterize these Land Systems were indicated as having Moderate Sensitivity according to the ARC model.

Table 18. Critical Loads and Derived Sensitivity Classes

\begin{tabular}{|c|c|c|c|c|c|c|c|c|}
\hline Land System & Soil Series & $\mathrm{pH}_{\mathrm{c}}{ }^{\mathrm{Z}}$ & $\mathrm{pH}_{\mathrm{h}}$ & $\begin{array}{c}\text { Texture 0-25 } \\
\text { cm }\end{array}$ & $\begin{array}{c}50 \mathrm{Yr} \\
\mathrm{CL}\end{array}$ & $\begin{array}{c}100 \mathrm{Yr} \\
\mathrm{CL}\end{array}$ & \begin{tabular}{|l|} 
H-F \\
Class \\
\end{tabular} & $\begin{array}{l}\text { Sensitivity } \\
\text { Class }\end{array}$ \\
\hline \multicolumn{9}{|l|}{ Luvisols } \\
\hline Islet Upland 1 & Uncas & 4.1 & 4.6 & $\begin{array}{l}\text { Sandy Loam - } \\
\text { Loam }\end{array}$ & $>1$ & $>1$ & M & L \\
\hline Islet Upland 2 & Cooking Lake & 5.0 & 5.4 & Sandy Loam & $>1$ & $>1$ & $\mathrm{M}$ & $L$ \\
\hline Islet Upland 3 & $\begin{array}{l}\text { Cooking Lake } \\
\text { (Forage) }\end{array}$ & 5.9 & 6.3 & Loam & $>1$ & 0.6 & M & L \\
\hline George Lake Plain 1 & Uncas & 4.1 & 4.6 & $\begin{array}{l}\text { Loamy Sand - } \\
\text { Sandy Loam }\end{array}$ & $>1$ & $>1$ & M & L \\
\hline George Lake Plain 2 & Cooking Lake & 5.3 & 5.7 & Loam & $>1$ & $>1$ & $\mathrm{M}$ & $L$ \\
\hline George Lake Plain 3 & Cooking Lake & 3.9 & 4.4 & $\begin{array}{l}\text { Very Fine } \\
\text { Sandy Loam }\end{array}$ & $>1$ & $>1$ & M & L \\
\hline George Lake Plain 4 & $\begin{array}{l}\text { Cooking Lake } \\
\text { (Forage) }\end{array}$ & 4.3 & 4.8 & $\begin{array}{l}\text { Very Fine } \\
\text { Sandy Loam }\end{array}$ & $>1$ & $>1$ & M & $\mathrm{L}$ \\
\hline $\begin{array}{l}\text { Yeoford Plain/ } \\
\text { Falun Plain }\end{array}$ & Breton & 5.3 & 5.7 & $\begin{array}{l}\text { Loam - } \\
\text { Silt Loam }\end{array}$ & $>1$ & $>1$ & M & $\mathrm{L}$ \\
\hline \multicolumn{9}{|l|}{ Brunisols } \\
\hline $\begin{array}{l}\text { Redwater Plain / } \\
\text { Halfway Lake } \\
\text { Dunefield }\end{array}$ & Nestow & 4.7 & 5.1 & Sand & 0.7 & 0.5 & $\mathrm{~L}$ & M \\
\hline $\begin{array}{l}\text { Redwater Plain } \\
\text { (Forage) }\end{array}$ & Nestow & 5.0 & 5.4 & Sand & 1 & 0.7 & L & L \\
\hline Graminia Plain 1 & Nestow & 5.3 & 5.7 & $\begin{array}{l}\text { Loamy Fine } \\
\text { Sand }\end{array}$ & $>1$ & $>1$ & $L(H)$ & $\mathrm{L}$ \\
\hline \multicolumn{9}{|l|}{ Chernozems } \\
\hline Graminia Plain 2 & Helliwell & 6.0 & 6.4 & Loamy Sand & $>1$ & $>1$ & $\mathrm{~L}$ & $\mathrm{~L}$ \\
\hline Pipestone Upland 1 & Helliwell & 4.8 & 5.2 & Loamy Sand & $>1$ & 0.8 & $L$ & $L$ \\
\hline Pipestone Upland 2 & Peace Hills & 5.2 & 5.6 & Sandy Loam & $>1$ & 0.8 & $L$ & $L$ \\
\hline
\end{tabular}

Abbreviations: $\mathrm{pH}_{\mathrm{c}}-\mathrm{pH}\left(\mathrm{CaCl}_{2}\right) ; \mathrm{pH}_{\mathrm{h}}-\mathrm{pH}\left(\mathrm{H}_{2} \mathrm{O}\right) ; \mathrm{CL}$ - critical load; $\mathrm{H}-\mathrm{F}$ Class - Holowaychuk-Fessenden sensitivity class $(\mathrm{H}-$ high, $\mathrm{M}$ - moderate, $\mathrm{L}-$ low, $\mathrm{L}(\mathrm{H})-$ Low and High)

Differences in the sensitivity classes are related to the level of detail of soil mapping. In the case of the sandy soil areas in the Redwater Plain, Halfway Lake Dunefield and Eldorena Plain, the $\mathrm{H}-\mathrm{F}$ map legend indicates that the soils have high organic matter content and high exchangeable cation content. These properties are associated with the finer textured soils that also occur in these Land Systems. However, there appears to have been very limited soil profile information for the sandiest soils in the region. These were mapped as 'Dune Sand' soils in the soil survey of the Edmonton sheet (Bowser et al. 1962), and were also apparently assumed to be characterized by relatively high organic matter and associated buffering capacity in sensitivity mapping. Since the publication of the acidification sensitivity map by Holowaychuk and Fessenden (1987), more detailed mapping has been carried out for the AGRASID (Agricultural Region of Alberta Soil Information Database) program (Alberta Soil Information Centre 2007). The sandy soils on eolian deposits were mapped as Eluviated Eutric Brunisols 
(Primula Soil Series). In the current study, the soil profiles sampled were Eluviated Dystric Brunisols and were designated as the Nestow Soil Series. It is likely that both of these soil series occur in the sandy landscapes of the Edmonton West grid cell, with the more acidic Nestow Soil Series being relatively more sensitive than the Primula Soil Series.

With regard to differences in the H-F map and the ARC model results for the Luvisolic soils of the Islet Upland and the Brunisolic soils of the Graminia Plain, the buffering capacity of the litter layer in these soils appears to be a major factor affecting sensitivity. In applying the ARC model, the effect of acid input on the litter was first calculated. The water percolating through the litter was thus reduced in acidity, and the impact on the mineral surface horizon(s) was diminished. The critical loads were based on the chemical effect on the mineral part of the soil $(0-25 \mathrm{~cm})$ and not on the litter. Consequently, the Luvisols under native forest in the Edmonton West grid cell were determined to have Low Sensitivity to acidification.

\subsection{SENSITIVITY MAP}

From the results in Table 19, critical loads mapping was based on assignment of the most acid sensitive soil series to categories as follows:

$\begin{array}{ll}\text { Nestow (Primula) } & \text { Moderate } \\ \text { All others } & \text { Low }\end{array}$

In assigning sensitivity categories to Land Systems, the derivation of critical loads for the Edmonton East map sheet was also considered. The Redwater Plain and Eldorena Plain Land Systems were determined to have a component of Sensitive soils along with both Moderate and Low Sensitivity soils. The proportions were estimated by assigning half of the Nestow and Primula soils to the Sensitive category, and the other half to the Moderate category. While no Sensitive categories were determined in the Edmonton West map area, it was assumed that some Sensitive soils do occur, and the proportions applied in the Edmonton East map sheet were also applied in the Edmonton West sheet. This approach also ensured that these Land Systems would be mapped uniformly across the boundary of these two map sheets.

A map depicting the Land Systems, land cover and soil sensitivity to acid inputs in the Edmonton West map sheet was developed based on soils and land cover information as described in Sections 3.1 and 3.3. The proportions of land cover in each Land System under the categories of Cultivated, Trees, Shrubs, Grasslands, Wetlands and Other Lands are provided in Appendix C.

The soil rating for sensitivity to acid inputs, as determined in the previous section, was superimposed on the land cover information. Proportions of soil series within Land Systems were estimated from information provided in Table 2, and from this, the proportions of soils in Moderate to Sensitive (Nestow and Primula and Low (all other soils) acidification sensitivity categories were derived. The sensitivity ratings were applied only to soils under grassland, tree, and shrub land cover types. Wetlands and cultivated soils were not rated, nor were lands categorized as 'Other Lands'. 
Table 19. Acidification Sensitivity of Land Systems in the Edmonton West Grid Cell

\begin{tabular}{|c|c|c|c|c|}
\hline $\begin{array}{l}\text { LAND } \\
\text { SYSTEM }\end{array}$ & LAND SYSTEM DESCRIPTION & MAJOR SOILS & MINOR SOILS & $\begin{array}{l}\text { ACIDIFICATION } \\
\text { SENSITIVITY }\end{array}$ \\
\hline $\begin{array}{l}05.00 .09 \\
\text { Battle River } \\
\text { Valley }\end{array}$ & $\begin{array}{l}\text { Landscape is valley bottom with some } \\
\text { confined floodplain. Regosols developed } \\
\text { on undifferentiated material. Minor soils } \\
\text { include coarse textured soils. Significant } \\
\text { eroded soils present. }\end{array}$ & $\begin{array}{l}\text { Miscellaneous } \\
\text { Eroded }\end{array}$ & $\begin{array}{l}\text { Milk River-AA } \\
\text { ( Cumulic } \\
\text { Regosol) }\end{array}$ & $\begin{array}{l}\text { Low }-51 \% \\
\text { Cultivated }-20 \% \\
\text { Wetland }-25 \% \\
\text { Other }-4 \%\end{array}$ \\
\hline $\begin{array}{l}05.3 \mathrm{~d} .01 \\
\text { Morinville } \\
\text { Plain }\end{array}$ & $\begin{array}{l}\text { Landscape is undulating. Black Solonetz } \\
\text { developed on medium textured till and } \\
\text { fine textured water-laid sediments. Minor } \\
\text { soils include Chernozems and Gleysols. }\end{array}$ & \begin{tabular}{|l|} 
Camrose \\
(Black Solodized \\
Solonetz) \\
Duagh \\
(Black Solonetz) \\
\end{tabular} & $\begin{array}{l}\text { Angus Ridge } \\
\text { (Eluviated Black } \\
\text { Chernozem) } \\
\text { Gleysols/Water }\end{array}$ & $\begin{array}{l}\text { Low }-32 \% \\
\text { Cultivated }-67 \% \\
\text { Wetland }-1 \%\end{array}$ \\
\hline $\begin{array}{l}\text { 05.3d.07 } \\
\text { Namao Plain }\end{array}$ & $\begin{array}{l}\text { Landscape is undulating. Black } \\
\text { Chernozems developed on fine textured } \\
\text { water-laid sediments and medium } \\
\text { textured water-laid sediments. }\end{array}$ & $\begin{array}{l}\text { Malmo } \\
\text { (Eluviated Black } \\
\text { Chernozem) } \\
\text { Ponoka } \\
\text { (Eluviated Black } \\
\text { Chernozem) } \\
\end{array}$ & \begin{tabular}{|l|} 
Angus Ridge \\
(Eluviated Black \\
Chernozem) \\
Mico \\
(Orthic Dark Gray \\
Chernozem)
\end{tabular} & $\begin{array}{l}\text { Low }-27 \% \\
\text { Cultivated }-69 \% \\
\text { Wetland }-1 \% \\
\text { Other }-2 \%\end{array}$ \\
\hline $\begin{array}{l}\text { 05.3d.09 } \\
\text { Partridge } \\
\text { Plain }\end{array}$ & $\begin{array}{l}\text { Landscape is undulating. Black } \\
\text { Chernozems developed on medium } \\
\text { textured till. Minor soils include Gleysols. }\end{array}$ & \begin{tabular}{|l|} 
Angus Ridge \\
(Eluviated Black \\
Chernozem)
\end{tabular} & \begin{tabular}{|l|} 
Rolly View \\
(Orthic Dark Gray \\
Chernozem) \\
Gleysols/Water
\end{tabular} & $\begin{array}{l}\text { Low - } 28 \% \\
\text { Cultivated - } 72 \%\end{array}$ \\
\hline $\begin{array}{l}05.3 \mathrm{~d} .10 \\
\text { Cawes Plain }\end{array}$ & $\begin{array}{l}\text { Landscape is undulating. Black } \\
\text { Chernozems developed on medium } \\
\text { textured till. }\end{array}$ & $\begin{array}{l}\text { Angus Ridge } \\
\text { (Eluviated Black } \\
\text { Chernozem) }\end{array}$ & \begin{tabular}{|l|} 
Hobbema \\
(Eluviated Black \\
Chernozem) \\
Rolly View \\
(Orthic Dark Gray \\
Chernozem)
\end{tabular} & $\begin{array}{l}\text { Low }-16 \% \\
\text { Cultivated }-83 \% \\
\text { Other }-1 \%\end{array}$ \\
\hline $\begin{array}{l}05.3 d .11 \\
\text { Pointe-aux- } \\
\text { Pins Plain }\end{array}$ & $\begin{array}{l}\text { Landscape is undulating. Black } \\
\text { Chernozems developed on fine textured } \\
\text { water-laid sediments. }\end{array}$ & $\begin{array}{l}\text { Malmo } \\
\text { (Eluviated Black } \\
\text { Chernozem) }\end{array}$ & \begin{tabular}{|l|} 
Angus Ridge \\
(Eluviated Black \\
Chernozem) \\
Looma \\
(Orthic Dark Gray \\
Chernozem) \\
\end{tabular} & $\begin{array}{l}\text { Low }-25 \% \\
\text { Cultivated }-72 \% \\
\text { Other }-3 \%\end{array}$ \\
\hline $\begin{array}{l}05.3 \mathrm{~d} .14 \\
\text { City of } \\
\text { Edmonton }\end{array}$ & City of Edmonton. & Disturbed & & $\begin{array}{l}\text { Low - } 19 \% \\
\text { Cultivated }-27 \% \\
\text { Wetland }-2 \% \\
\text { Other }-52 \% \\
\end{array}$ \\
\hline $\begin{array}{l}05.3 \mathrm{~d} .18 \\
\text { Spruce Grove } \\
\text { Plain }\end{array}$ & $\begin{array}{l}\text { Landscape is undulating with some } \\
\text { peatlands. Dark Gray Chernozems } \\
\text { developed on medium textured water- } \\
\text { laid sediments. Minor soils include } \\
\text { Organic and fine textured soils. }\end{array}$ & $\begin{array}{l}\text { Winterburn } \\
\text { (Orthic Dark Gray) }\end{array}$ & $\begin{array}{l}\text { Organics } \\
\text { Malmo } \\
\text { (Eluviated Black } \\
\text { Chernozem) }\end{array}$ & $\begin{array}{l}\text { Low }-36 \% \\
\text { Cultivated }-53 \% \\
\text { Wetland }-7 \% \\
\text { Other }-4 \%\end{array}$ \\
\hline $\begin{array}{l}05.3 d .19 \\
\text { Longhurst } \\
\text { Plain }\end{array}$ & $\begin{array}{l}\text { Landscape is undulating with some } \\
\text { peatlands. Dark Gray Chernozems } \\
\text { developed on medium textured water- } \\
\text { laid sediments. Minor soils include } \\
\text { Organic and coarse textured soils. }\end{array}$ & $\begin{array}{l}\text { Winterburn } \\
\text { (Orthic Dark Gray) }\end{array}$ & \begin{tabular}{|l|} 
Redwater \\
(Orthic Dark Gray \\
Chernozem) \\
Organics
\end{tabular} & $\begin{array}{l}\text { Low }-26 \% \\
\text { Cultivated }-71 \% \\
\text { Wetland }-1 \% \\
\text { Other }-2 \%\end{array}$ \\
\hline $\begin{array}{l}\text { 05.3d.20 } \\
\text { Graminia } \\
\text { Plain }\end{array}$ & $\begin{array}{l}\text { Landscape is undulating with some } \\
\text { duned. Dark Gray Luvisols developed } \\
\text { on coarse textured sediments. Minor } \\
\text { soils include Organic. }\end{array}$ & \begin{tabular}{|l|} 
Elk Point \\
(Dark Gray Luvisol) \\
Tiger Lily \\
(Orthic Gray Luvisol)
\end{tabular} & Organics & $\begin{array}{l}\text { Low - } 57 \% \\
\text { Cultivated - } 42 \% \\
\text { Wetland - } 1 \%\end{array}$ \\
\hline
\end{tabular}


Table 19. Acidification Sensitivity of Land Systems in the Edmonton West Grid Cell

\begin{tabular}{|c|c|c|c|c|}
\hline $\begin{array}{l}\text { LAND } \\
\text { SYSTEM }\end{array}$ & LAND SYSTEM DESCRIPTION & MAJOR SOILS & MINOR SOILS & $\begin{array}{l}\text { ACIDIFICATION } \\
\text { SENSITIVITY }\end{array}$ \\
\hline $\begin{array}{l}05.3 \mathrm{~d} .21 \\
\text { Calmar Plain }\end{array}$ & $\begin{array}{l}\text { Landscape is undulating. Black } \\
\text { Chernozems developed on fine textured } \\
\text { water-laid sediments. }\end{array}$ & $\begin{array}{l}\text { Malmo } \\
\text { (Eluviated Black } \\
\text { Chernozem) }\end{array}$ & \begin{tabular}{|l|} 
Ponoka \\
(Eluviated Black \\
Chernozem) \\
Looma \\
(Orthic Dark Gray \\
Chernozem) \\
\end{tabular} & $\begin{array}{l}\text { Low }-9 \% \\
\text { Cultivated }-88 \% \\
\text { Other }-3 \%\end{array}$ \\
\hline $\begin{array}{l}05.3 \mathrm{~d} .22 \\
\text { Watelet Plain }\end{array}$ & $\begin{array}{l}\text { Landscape is undulating. Black } \\
\text { Chernozems and Black Solonetz } \\
\text { developed on medium textured till and } \\
\text { medium textured softrock. }\end{array}$ & $\begin{array}{l}\text { Angus Ridge } \\
\text { (Eluviated Black } \\
\text { Chernozem) } \\
\text { Kavanagh } \\
\text { (Black Solodized } \\
\text { Solonetz) } \\
\end{array}$ & $\begin{array}{l}\text { Hobbema } \\
\text { Rolly View } \\
\text { (Orthic Dark Gray } \\
\text { Chernozem) }\end{array}$ & $\begin{array}{l}\text { Low }-20 \% \\
\text { Cultivated }-76 \% \\
\text { Other }-4 \%\end{array}$ \\
\hline $\begin{array}{l}05.3 \mathrm{~d} .26 \\
\text { Big Hay Plain }\end{array}$ & $\begin{array}{l}\text { Landscape is undulating with some } \\
\text { level, closed basin. Black Chernozems } \\
\text { and Black Solonetz developed on } \\
\text { medium textured till and fine textured } \\
\text { water-laid sediments. Minor soils include } \\
\text { Gleysols. }\end{array}$ & $\begin{array}{l}\text { Angus Ridge } \\
\text { (Eluviated Black } \\
\text { Chernozem) } \\
\text { Wetaskiwin } \\
\text { (Black Solodized } \\
\text { Solonetz) } \\
\end{array}$ & $\begin{array}{l}\text { Malmo } \\
\text { (Eluviated Black } \\
\text { Chernozem) } \\
\text { Gleysols/Water }\end{array}$ & $\begin{array}{l}\text { Low }-42 \% \\
\text { Cultivated }-54 \% \\
\text { Wetland }-3 \& \\
\text { Other }-1 \%\end{array}$ \\
\hline $\begin{array}{l}05.3 \mathrm{~d} .27 \\
\text { Ferlow Plain }\end{array}$ & $\begin{array}{l}\text { Landscape is hummocky. Black } \\
\text { Chernozems developed on medium } \\
\text { textured till. Minor soils include Gleysols. }\end{array}$ & $\begin{array}{l}\text { Angus Ridge } \\
\text { (Eluviated Black } \\
\text { Chernozem) }\end{array}$ & $\begin{array}{l}\text { Rolly View } \\
\text { (Orthic Dark Gray } \\
\text { Chernozem) } \\
\text { Gleysols/Water } \\
\end{array}$ & $\begin{array}{l}\text { Low }-34 \% \\
\text { Cultivated }-65 \% \\
\text { Wetland }-1 \%\end{array}$ \\
\hline $\begin{array}{l}\text { 05.3d.28 } \\
\text { Pipestone } \\
\text { Upland }\end{array}$ & $\begin{array}{l}\text { Landscape is undulating with some } \\
\text { duned. Black Chernozems developed on } \\
\text { coarse textured sediments and medium } \\
\text { textured water-laid sediments. Minor } \\
\text { soils include Gleysols. }\end{array}$ & $\begin{array}{l}\text { Peace Hills } \\
\text { (Orthic Black } \\
\text { Chernozem) } \\
\text { Ponoka } \\
\text { (Eluviated Black } \\
\text { Chernozem) } \\
\end{array}$ & Gleysols/Water & $\begin{array}{l}\text { Low }-43 \% \\
\text { Cultivated }-55 \% \\
\text { Wetland }-1 \% \\
\text { Other }-1 \%\end{array}$ \\
\hline $\begin{array}{l}05.3 \mathrm{~d} .30 \\
\text { Bigstone Plain }\end{array}$ & $\begin{array}{l}\text { Landscape is undulating with some } \\
\text { duned. Black Chernozems developed on } \\
\text { coarse textured sediments and medium } \\
\text { textured material over medium textured } \\
\text { till. Minor soils include Gleysols. }\end{array}$ & $\begin{array}{l}\text { Peace Hills } \\
\text { (Orthic Black } \\
\text { Chernozem) } \\
\text { Hobbema } \\
\text { (Eluviated Black } \\
\text { Chernozem) }\end{array}$ & $\begin{array}{l}\text { Ponoka } \\
\text { (Eluviated Black } \\
\text { Chernozem) } \\
\text { Gleysols/Water }\end{array}$ & $\begin{array}{l}\text { Low - } 20 \% \\
\text { Cultivated }-80 \%\end{array}$ \\
\hline $\begin{array}{l}\text { 05.3d.31 } \\
\text { Samson Lake } \\
\text { Plain }\end{array}$ & $\begin{array}{l}\text { Landscape is undulating. Black } \\
\text { Chernozems developed on fine textured } \\
\text { water-laid sediments. Minor soils include } \\
\text { Solonetz and Gleysols. }\end{array}$ & $\begin{array}{l}\text { Malmo } \\
\text { (Eluviated Black } \\
\text { Chernozem) }\end{array}$ & $\begin{array}{l}\text { Gleysols/Water } \\
\text { Gleysols/Water }\end{array}$ & $\begin{array}{l}\text { Low }-41 \% \\
\text { Cultivated }-58 \% \\
\text { Wetland }-1 \%\end{array}$ \\
\hline $\begin{array}{l}05.3 \mathrm{~d} .50 \\
\text { Looma Upland }\end{array}$ & $\begin{array}{l}\text { Landscape is hummocky. Dark Gray } \\
\text { Chernozems and Dark Gray Luvisols } \\
\text { developed on medium textured till. Minor } \\
\text { soils include Gleysols and fine textured } \\
\text { soils. }\end{array}$ & $\begin{array}{l}\text { Uncas } \\
\text { (Dark Gray Luvisol)) } \\
\text { Uncas } \\
\text { (Dark Gray Luvisol) }\end{array}$ & $\begin{array}{l}\text { Mico } \\
\text { (Orthic Dark Gray } \\
\text { Chernozem) } \\
\text { Gleysols/Water }\end{array}$ & $\begin{array}{l}\text { Low }-57 \% \\
\text { Cultivated }-42 \% \\
\text { Wetland }-1 \%\end{array}$ \\
\hline $\begin{array}{l}05.4 a .15 \\
\text { Ryley Plain }\end{array}$ & $\begin{array}{l}\text { Landscape is undulating. Black Solonetz } \\
\text { developed on medium textured till. Minor } \\
\text { soils include Chernozems and Gleysols. }\end{array}$ & $\begin{array}{l}\text { Camrose } \\
\text { (Black Solodized } \\
\text { Solonetz) }\end{array}$ & \begin{tabular}{|l|} 
Norma \\
(Solonetzic Black \\
Chernozem) \\
Gleysols/Water \\
\end{tabular} & $\begin{array}{l}\text { Low - } 35 \% \\
\text { Cultivated }-36 \% \\
\text { Wetland }-29 \%\end{array}$ \\
\hline $\begin{array}{l}05.6 .01 \\
\text { Islet Upland }\end{array}$ & $\begin{array}{l}\text { Landscape is hummocky. Dark Gray } \\
\text { and Dark Gray Luvisols developed on } \\
\text { medium textured till. Minor soils include } \\
\text { Gleysols, Chernozems and fine textured } \\
\text { soils. }\end{array}$ & $\begin{array}{l}\text { Cooking Lake } \\
\text { (Orthic Gray Luvisol) } \\
\text { Uncas } \\
\text { (Dark Gray Luvisol) }\end{array}$ & $\begin{array}{l}\text { Gleysols/Water } \\
\text { Mico } \\
\text { (Orthic Dark Gray } \\
\text { Chernozem) }\end{array}$ & $\begin{array}{l}\text { Low - } 68 \% \\
\text { Cultivated }-21 \% \\
\text { Wetland }-11 \%\end{array}$ \\
\hline
\end{tabular}


Table 19. Acidification Sensitivity of Land Systems in the Edmonton West Grid Cell

\begin{tabular}{|c|c|c|c|c|}
\hline $\begin{array}{l}\text { LAND } \\
\text { SYSTEM }\end{array}$ & LAND SYSTEM DESCRIPTION & MAJOR SOILS & MINOR SOILS & $\begin{array}{c}\text { ACIDIFICATION } \\
\text { SENSITIVITY }\end{array}$ \\
\hline \begin{tabular}{|l|}
06.00 .03 \\
North \\
Saskatchewan \\
River Valley \\
\end{tabular} & $\begin{array}{l}\text { Landscape is inclined }<10 \% \text { exposed } \\
\text { bedrock with some numerous water } \\
\text { bodies and undulating. }\end{array}$ & $\begin{array}{l}\text { Miscellaneous } \\
\text { Eroded }\end{array}$ & & $\begin{array}{l}\text { Low }-54 \% \\
\text { Cultivated }-29 \% \\
\text { Wetland - } 16 \% \\
\text { Other }-1 \% \\
\end{array}$ \\
\hline $\begin{array}{l}06.1 \mathrm{~b} .02 \\
\text { Yeoford Plain }\end{array}$ & $\begin{array}{l}\text { Landscape is undulating with some } \\
\text { rolling and hummocky. Dark Gray and } \\
\text { Gray Luvisols developed on medium } \\
\text { textured till. Minor soils include } \\
\text { Chernozems. }\end{array}$ & $\begin{array}{l}\text { Benalto } \\
\text { (Dark Gray Luvisol) } \\
\text { Breton } \\
\text { (Orthic Gray Luvisol) }\end{array}$ & \begin{tabular}{|l|} 
Falun \\
(Orthic Dark Gray \\
Chernozem) \\
Keephills \\
(Dark Gray \\
Luvisol) \\
\end{tabular} & $\begin{array}{l}\text { Low - } 44 \% \\
\text { Cultivated - } 56 \%\end{array}$ \\
\hline $\begin{array}{l}.1 \mathrm{~b} .03 \\
\text { geon Lake }\end{array}$ & Large water body. & N/A & N/A & Water $-100 \%$ \\
\hline $\begin{array}{l}06.1 \mathrm{c} .12 \\
\text { Falun Plain }\end{array}$ & $\begin{array}{l}\text { Landscape is undulating. Dark Gray } \\
\text { Luvisols and Dark Gray Chernozems } \\
\text { developed on medium textured till. } \\
\text { Minor soils include Organic. }\end{array}$ & \begin{tabular}{|l|} 
Benalto \\
(Dark Gray Luvisol) \\
Falun \\
(Orthic Dark Gray \\
Chernozem) \\
\end{tabular} & $\begin{array}{l}\text { Breton } \\
\text { (Orthic Gray } \\
\text { Luvisol) } \\
\text { Organics }\end{array}$ & $\begin{array}{l}\text { Low - } 41 \% \\
\text { Cultivated }-57 \% \\
\text { Wetland }-2 \%\end{array}$ \\
\hline $\begin{array}{l}06.1 \mathrm{~d} .02 \\
\text { George Lake } \\
\text { Plain }\end{array}$ & $\begin{array}{l}\text { Landscape is hummocky with some } \\
\text { numerous water bodies. Gray Luvisols } \\
\text { and Gray Solonetz developed on } \\
\text { medium textured till. Minor soils include } \\
\text { Gleysols. }\end{array}$ & \begin{tabular}{|l|} 
Cooking Lake \\
(Orthic Gray Luvisol) \\
Dnister \\
(Gray Solodized \\
Solonetz) \\
\end{tabular} & $\begin{array}{l}\text { Nakamun } \\
\text { (Solonetzic Gray } \\
\text { Luvisol) } \\
\text { Gleysols/Water }\end{array}$ & $\begin{array}{l}\text { Low - } 64 \% \\
\text { Cultivated }-36 \%\end{array}$ \\
\hline $\begin{array}{l}06.1 \mathrm{~d} .08 \\
\text { Onoway } \\
\text { Upland }\end{array}$ & $\begin{array}{l}\text { Landscape is hummocky. Gray and } \\
\text { Dark Gray Luvisols developed on } \\
\text { medium textured till. Minor soils include } \\
\text { Organic and Chernozems. }\end{array}$ & $\begin{array}{l}\text { Cooking Lake } \\
\text { (Orthic Gray Luvisol) } \\
\text { Uncas } \\
\text { (Dark Gray Luvisol) } \\
\end{array}$ & \begin{tabular}{|l|} 
Organics \\
Miscellaneous \\
Coarse Textured \\
Soils \\
\end{tabular} & $\begin{array}{l}\text { Low }-67 \% \\
\text { Cultivated }-30 \% \\
\text { Wetland - } 3 \%\end{array}$ \\
\hline $\begin{array}{l}\text { 06.1d.20 } \\
\text { Mink Lake } \\
\text { Plain }\end{array}$ & $\begin{array}{l}\text { Landscape is hummocky. Gray Luvisols } \\
\text { developed on medium textured water- } \\
\text { laid sediments. }\end{array}$ & $\begin{array}{l}\text { Glory } \\
\text { (Orthic Gray Luvisol) } \\
\text { Highvale } \\
\text { (Orthic Gray Luvisol) }\end{array}$ & $\begin{array}{l}\text { Carvel } \\
\text { (Dark Gray } \\
\text { Luvisol) } \\
\text { Keephills } \\
\text { (Dark Gray } \\
\text { Luvisol) }\end{array}$ & $\begin{array}{l}\text { Low - } 53 \% \\
\text { Cultivated - } 47 \%\end{array}$ \\
\hline $\begin{array}{l}06.1 \mathrm{~d} .21 \\
\text { Pemburton Hill } \\
\text { Plain }\end{array}$ & $\begin{array}{l}\text { Landscape is undulating. Dark Gray } \\
\text { Luvisols developed on very fine textured } \\
\text { water-laid sediments and areas of } \\
\text { moderately fine textured till. Minor soils } \\
\text { include Gleysols. }\end{array}$ & $\begin{array}{l}\text { Macola } \\
\text { (Dark Gray Luvisol) }\end{array}$ & $\begin{array}{l}\text { Boscombe } \\
\text { (Gleyed Dark } \\
\text { Gray Luvisol) } \\
\text { Gleysols/Water }\end{array}$ & $\begin{array}{l}\text { Low - } 72 \% \\
\text { Cultivated - } 28 \%\end{array}$ \\
\hline $\begin{array}{l}06.2 \mathrm{a} .05 \\
\text { Redwater } \\
\text { Plain }\end{array}$ & $\begin{array}{l}\text { Landscape is undulating with some } \\
\text { duned. Black Chernozems developed } \\
\text { on coarse textured sediments. Minor } \\
\text { soils include Brunisols. }\end{array}$ & $\begin{array}{l}\text { Mundare } \\
\text { (Orthic Black } \\
\text { Chernozem) }\end{array}$ & \begin{tabular}{|l|} 
Primula \\
(Eluviated Eutric \\
Brunisol) \\
Peace Hills \\
(Orthic Black \\
Chernozem) \\
\end{tabular} & $\begin{array}{l}\text { Low - } 28 \% \\
\text { Moderate - } 34 \% \\
\text { Sensitive }-7 \% \\
\text { Cultivated - } 31 \%\end{array}$ \\
\hline $\begin{array}{l}\text { 06.2a.09 } \\
\text { Halfway Lake } \\
\text { Dunefield }\end{array}$ & $\begin{array}{l}\text { Landscape is undulating and duned. } \\
\text { Brunisols and Dark Gray Chernozems } \\
\text { developed on coarse textured } \\
\text { sediments. Minor soils include Organic } \\
\text { and Gleysols. }\end{array}$ & $\begin{array}{l}\text { Primula } \\
\text { (Eluviated Eutric } \\
\text { Brunisol) } \\
\text { Helliwell } \\
\text { (Orthic Dark Gray } \\
\text { Chernozem) } \\
\end{array}$ & $\begin{array}{l}\text { Organics } \\
\text { Gleysols/Water }\end{array}$ & $\begin{array}{l}\text { Low }-36 \% \\
\text { Moderate }-38 \% \\
\text { Sensitive }-17 \% \\
\text { Cultivated }-9 \%\end{array}$ \\
\hline $\begin{array}{l}06.2 a .11 \\
\text { Eldorena Plain }\end{array}$ & $\begin{array}{l}\text { Landscape is undulating with some } \\
\text { duned. Black Chernozems and } \\
\text { Brunisols developed on coarse textured } \\
\text { sediments. }\end{array}$ & $\begin{array}{l}\text { Peace Hills } \\
\text { (Orthic Black } \\
\text { Chernozem) } \\
\text { Primula } \\
\text { (Eluviated Eutric } \\
\text { Brunisol) } \\
\end{array}$ & $\begin{array}{l}\text { Manatokan-AA } \\
\text { (Terric Mesisol) } \\
\text { Mundare } \\
\text { (Orthic Black } \\
\text { Chernozem) }\end{array}$ & $\begin{array}{l}\text { Low }-39 \% \\
\text { Moderate }-25 \% \\
\text { Sensitive }-17 \% \\
\text { Cultivated }-18\end{array}$ \\
\hline
\end{tabular}


Table 19. Acidification Sensitivity of Land Systems in the Edmonton West Grid Cell

\begin{tabular}{|c|c|c|c|c|}
\hline $\begin{array}{l}\text { LAND } \\
\text { SYSTEM }\end{array}$ & LAND SYSTEM DESCRIPTION & MAJOR SOILS & MINOR SOILS & $\begin{array}{l}\text { ACIDIFICATION } \\
\text { SENSITIVITY } \\
\end{array}$ \\
\hline $\begin{array}{l}06.2 b .17 \\
\text { Pakan Plain }\end{array}$ & $\begin{array}{l}\text { Landscape is undulating. Black } \\
\text { Chernozems developed on medium } \\
\text { textured water-laid sediments. Minor } \\
\text { soils include Solonetz. }\end{array}$ & $\begin{array}{l}\text { Ponoka } \\
\text { (Eluviated Black } \\
\text { Chernozem) }\end{array}$ & \begin{tabular}{|l} 
Hobbema \\
(Eluviated Black \\
Chernozem) \\
Kavanagh \\
(Black Solodized \\
Solonetz) \\
\end{tabular} & $\begin{array}{l}\text { Low - } 69 \% \\
\text { Cultivated - } 27 \% \\
\text { Other - } 4 \%\end{array}$ \\
\hline $\begin{array}{l}06.2 c .25 \\
\text { Thorhild Plain }\end{array}$ & $\begin{array}{l}\text { Landscape is undulating. Dark Gray } \\
\text { Luvisols and Dark Gray Chernozems } \\
\text { developed on medium textured till. } \\
\text { Minor soils include Gleysols. }\end{array}$ & $\begin{array}{l}\text { Spedden } \\
\text { (Orthic Dark Gray } \\
\text { Chernozem) } \\
\text { Kehiwin } \\
\text { (Dark Gray Luvisol) }\end{array}$ & $\begin{array}{l}\text { La Corey } \\
\text { (Orthic Gray } \\
\text { Luvisol) } \\
\text { Gleysols/Water }\end{array}$ & $\begin{array}{l}\text { Low - } 46 \% \\
\text { Cultivated - } 54 \%\end{array}$ \\
\hline
\end{tabular}

The sensitivity category proportions in the various Land Systems are given in Table 20. Only the Redwater Plain, Eldorena Plain and the Halfway Lake Dunefield Land Systems were assigned components of the Sensitive or Moderate categories, as indicated above. The derivation of percentages of different sensitivity classes in these Land Systems is provided in Appendix D.

For purposes of developing a soil sensitivity map, the Land Systems with Sensitive and/or Moderate inclusions were grouped together such that there were two Sensitivity categories on the map. These generalized categories, and the Land Systems in the categories, are indicated in Table 20.

Table 20. Land System Acidification Sensitivity Categories

\begin{tabular}{|c|c|}
\hline Acidification Sensitivity Category & Land System \\
\hline Low - Moderate - Sensitive Mix & $\begin{array}{c}\text { Redwater Plain } \\
\text { Halfway Lake Dunefield } \\
\text { Eldorena Plain }\end{array}$ \\
\hline Low & All other Land Systems \\
\hline
\end{tabular}

The above sensitivity categories were identified by colour coding on the critical loads map. The information from Table 20 is presented as a legend on the map. The map is provided on a CD as well as in hard copy form in the back pocket of this report. 


\subsection{CONCLUSIONS}

The objective of this study was to derive critical loads for soils in the Edmonton West map sheet, an area identified as possibly having significant areas of Sensitive and Moderate Sensitivity soils in the sensitivity classification of Holowaychuk and Fessenden (1987). Critical loads as low as $0.7 \mathrm{kmol} \mathrm{H}^{+} \mathrm{ha}^{-1} \mathrm{yr}^{-1}$ over a 50 year assessment period, and $0.5 \mathrm{kmol} \mathrm{H}^{+} \mathrm{ha}^{-1} \mathrm{yr}^{-1}$ over a 100 year assessment period were estimated by application of the ARC soil acidification model. Most soils were determined to have critical loads greater than $1.0 \mathrm{kmol} \mathrm{H}^{+} \mathrm{ha}^{-1} \mathrm{yr}^{-1}$. Critical loads determined by two other methods, namely the empirical method and the Steady State Mass Balance method, both based mainly on weathering estimates, were in general agreement with critical loads based on the ARC model.

Portions of three land systems in the Edmonton $83 \mathrm{H}$ West Half grid cell were characterized as having a component of Sensitive and Moderately Sensitive soils. These are the Redwater Plain, Halfway Lake Dunefield, and Eldorena Plain. Other Land Systems likely have small components of Sensitive and Moderately Sensitive soils, but of too low extent to enable mapping at the scale applied in this assessment. The assignment of Sensitive, Moderate and Low Sensitivity categories was applied only to lands classified as having grassland, tree or shrub cover, on the basis of 1993-1995 land use mapping by the Prairie Farm Rehabilitation Administration. Sensitive soils account for $0.65 \%$ and Moderately Sensitive soils account for $2.3 \%$ of the entire grid cell area. As defined in the Acid Deposition Management Framework (Clean Air Strategic Alliance and Alberta Environment 1999), this finding does not support the assignment of this grid cell to a Sensitive or Moderate Sensitivity rating. 
Abboud, S.A. and L.W. Turchenek. 1990. Assessment of present and potential effects of acidic and acidifying air pollutants on Alberta soils. In Acidic deposition: sulfur and nitrogen oxides, The Alberta Government/Industry Acid Deposition Research Program (ADRP). A.H. Legge and S.V. Krupa (Eds). Lewis Publishers, Chelsea, Michigan. pp. 555-605.

Abboud, S.A. and L.W. Turchenek. 2009. Site-specific critical loads of acid deposition on soils in the Edmonton 83H East map sheet, Alberta. Prepared for Alberta Environment. Land Monitoring Team. Edmonton, AB. 61 pp, appendices and map.

Abboud, S. A., L. W. Turchenek, L.W. and Halsey, L.A. 2002. Critical loads of acid deposition on soils in the Athabasca Oil Sands Region, Alberta. Prep. By Alberta Research Council, AMEC Earth \& Environmental Ltd., and University of Alberta, for $\mathrm{NOx}-\mathrm{SO}_{2}$ Management Working Group, Cumulative Environmental Management Association. Edmonton, AB.

Aherne, J. and S.A. Watmough. 2006. Calculating critical loads of acid deposition for forest soils in Manitoba and Saskatchewan. PN1372. Canadian Council of Ministers of the Environment. Ottawa.

Alberta Soil Information Centre, Alberta Agriculture and Rural Development. 2007. Agriculture Region of Alberta Soil Inventory Database (AGRASID 3.0). http://www1.agric.gov.ab.ca/\$department/deptdocs.nsf/all/sag6903).

Bache, B.W. 1980. The acidification of soils. In T.C. Hutchinson and M. Havas (eds.) Effects of Acid Precipitation of Terrestrial Ecosystems. Plenum Press, New York. Pp. 183 - 202.

Bloom, P.R. and D.F. Grigal. 1985. Modelling soil response to acid deposition in nonsulfate adsorbing soils. Journal of Environmental Quality 14: 489-495.

Bothe, R.A. and C. Abraham. 1993. Evaporation and evapotranspiration in Alberta 1986 to 1992 addendum. Surface Water Assessment Branch, Alberta Environmental Protection. Edmonton, Alberta.

Bowser, W.E. et al. 1962. Soil Survey of Edmonton Sheet $(83 \mathrm{H})$. Canada Department of Agriculture. Alberta Soil Survey Report No. 21.

Cheng, L. and R.P. Angle. 1996. Model-calculated interannual variability of concentration, deposition and transboundary transport of anthropogenic sulphur and nitrogen in Alberta. Atmos. Environ. 23: 4,021-4,030.

Cheng, L., R.P. Angle, E. Peake and H.S. Sandhu. 1995. Effective acidity modelling to establish acidic deposition objectives and manage emissions. Atmos. Environ. 29: 383-392. 
Cheng, L., K. McDonald, D. Fox and R. Angle. 1997. Total potential acid input in Alberta. The Target Loading Subgroup $\mathrm{SO}_{2}$ Management Project Team Alberta Clean Air Strategic Alliance. 1494-A9701.

Clean Air Strategic Alliance and Alberta Environment. 1999. Application of Critical, Target and Monitoring Loads for the Evaluation and Management of Acid Deposition. Publication No. T/472. Alberta Environment, Edmonton, Alberta. 67 pp.

Cronan, C.S. and D.F. Grigal. 1995. Use of calcium/aluminum ratios as indicators of stress in forest ecosystems. J. Environ. Qual. 24: 209-226.

Cronan, C.S. and C.L. Schofield. 1990. Relationships between aqueous aluminum and acidic deposition in forested watersheds of North America and northern Europe. Environ. Sci. Technol. 24: 1100-1105.

de Vries, W. 1991. Methodologies for the assessment and mapping of critical loads and of the impact of abatement strategies on forest soils. Rpt 46. DLO The Winand Staring Centre for Integrated Land, Soil and Water Research. Wageningen, The Netherlands. 109 pp.

de Vries, W. 1993. Average critical loads for nitrogen and sulfur and it use in acidification abatement policy in the Netherlands. Water, Air and Soil Pollut. 68: 399-434.

Downing, R.J., J.-P. Hettelingh and P.A.M. de Smet (eds.). 1993. Calculation and mapping of critical loads in Europe: Status Report 1993. RIVM Rep. 259101003. Bilthoven, The Netherlands. $163 \mathrm{pp}$.

Ecological Stratification Working Group. 1995. A National Ecological Framework for Canada. Agriculture and Agri-Food Canada, Research Branch, Centre for Land and Biological Resources Research and Environment Canada, State of the Environment Directorate, Ecozone Analysis Branch, Ottawa/Hull. Report and national map at 1:7,500,000 scale. (Also website http://www.ec.gc.ca/soer-ree/English/Framework/NarDesc/praire e.cfm )

Edmeades, D.C., D.M. Wheeler, and R.A. Christie. 1991. The effects of aluminium and pH on the growth of a range of temperate grass species and cultivars. Dev. Plant Soil Sci. 45: 913-924.

Environment Canada. 1993. Canadian Climate Normals, 1961 - 1990. Atmospheric Environment Service.

Environment Canada, 2006. Canadian Climate Normals and Averages 1971-2000. Atmospheric Environment Service [online]. Available: http://www.climate.weatheroffice.ec.gc.ca/climate normals/index e.html

Heady, H.F. and R.D. Child. 1994. Rangeland ecology and management. Westview Press, Boulder. $521 \mathrm{pp}$. 
Henderhot, W.H., H. Lalande and M. Duquette. 1993. Soil reaction and exchange acidity. Chapter 16 in Canadian Society of Soil Science (M. Carter, ed.), Soil Sampling and Methods of Analysis. Lewis Publishers, Boca Raton.

Henriksen, A., L. Lien and T.S. Traaen. 1990. Critical loads for surface waters - chemical criteria for inputs of strong acids. Acid Rain Research Report 22/1990. Norwegian Institute for Water Research, Oslo. 45 pp.

Henriksen, A., M. Posch, H. Hultberg and L. Lien. 1995. Critical loads of acidity for surface waters: Can the $\mathrm{ANC}_{\text {limit }}$ be considered variable? Water, Air Soil Pollut. 21: 1591-1601.

Holowaychuk, N. and R.J. Fessenden. 1987. Soil sensitivity to acid deposition and the potential of soils and geology in Alberta to reduce the acidity of acidic inputs. Earth Sciences Report 87-1, Alta Res. Council, Edmonton. 38 pp.

Hornung, M. K.R. Bull, M. Cresser, J. Hall, S.J. Langan, P. Loveland and C. Smith. 1995. An empirical map of critical loads of acidity for soils in Great Britain. Environ. Pollution. 90: 301-310.

Hoyt, P.B., M. Nyborg and H. Ukrainetz. 1981. Degradation by acidification. Proc. $18^{\text {th }}$ Annual Soil Science Workshop. 1981 February 24-25. Edmonton, Alberta. pp. 47-71.

Jenkins, A., B. J. Cosby, R. C. Ferrier, T. Larssen, and M. Posch. 2003. Assessing emission reduction targets with dynamic models: deriving target load functions for use in integrated assessment. Hydrology and Earth System Sciences 7: 609-617.

Kalra, Y.P. and D.G. Maynard. 1991. Methods manual for forest soil and plant analysis. Northwest Region, Information Report NOR-X-319. Forestry Canada, Northwestern Region, Northern Forestry Centre, Edmonton, Alberta. 116 pp.

Levine, E.R. and E.J. Ciolkosz. 1988. Computer simulation of soil sensitivity to acid rain. Soil Sci. Soc. Amer. J. 52: 209-215.

Lindsay, W.L. 1979. Chemical equilibria in soils. Wiley, New York.

Maynard, D.G. 1996. Critical and target loading of soils and vegetation in Alberta. Final report of the Target Loading Subgroup. Edmonton, Alberta. $48 \mathrm{pp}$.

McBride, M.B. 1994. Environmental chemistry of soils. Oxford Univ. Press, New York. 406 pp.

McKeague, J.A., ed. 1978. Manual on Soil Sampling and Methods of Analysis, 2nd edition. Ottawa: Canadian Society of Soil Science. 212 pp.

Miewes, K.J., P.K. Khanna and B. Ulrich. 1986. Parameters for describing soil acidification and their relevance to the stability of forest ecosystems. For. Ecol. Manage. 15: 161-179. 
Nilsson, S.I. 1986. Critical deposition limits for forest soils. In J. Nilsson, ed., Critical Loads For Sulphur and Nitrogen, report from a Nordic working group. Copenhagen: Nordic Council. $151 \mathrm{pp}$.

Nilsson, S.I. and P. Grennfelt (eds.). 1988. Critical Loads For Sulphur and Nitrogen. NORD 1988:97, Nordic Council of ministers. Copenhagen, Denmark. 418 pp.

Palmer, C.J. and D.O Trew. 1987. The sensitivity of Alberta lakes and soils to acidic deposition: Overview report. Prep. for Environment Protection Services, Alberta Environment. 28 pp.

Pauls, R.W., S.A. Abboud and L.W. Turchenek. 1996. Pollutant deposition impacts on lichens, mosses, wood and soil in the Athabasca oil sands area. Prepared for Syncrude Canada Ltd., Fort McMurray, Alberta, by Alberta Research Council. 223 pp. and Appendix Volume.

Penney, D.C., M. Nyborg, P.B. Hoyt, W.A. Rice, B. Siemens and D.H. Laverty. 1977. An assessment of the soil acidity problem in Alberta and northeastern British Columbia. Proc. $15^{\text {th }}$ Annual Soil Science Workshop. 1977 February 1-2. Edmonton, Alberta. pp. 179-189.

PFRA. 2001. PFRA Generalized Land Cover. Prairie Farm Rehabilitation Administration. Regina, SK. Available: http://www.agriperi.ir/english/workshop/supporting\%20research\%20articles/PFRA\%20Land\%20Cover.p df

Posch, M., P.A.M. de Smet J.-P. Hettelingh, and R.J. Downing (eds.). 1995. Calculation and mapping of critical thresholds in Europe: Status Report 1995. RIVM Rep. 259101004. Bilthoven, The Netherlands. $198 \mathrm{pp}$.

Posch, M., J.-P. Hettelingh and J. Slootweg (eds.). 2003. Manual for dynamic modelling of soil resources to atmospheric acid deposition. Report 259101012/2003. ICP M\&M Coordination Center for Effects. Netherlands Environmental Assessment Agency. Bilthoven, The Netherlands. $163 \mathrm{pp}$.

Posch, M., P.A.M. de Smet J.-P. Hettelingh, and R.J. Downing (eds.). 1997. Calculation and mapping of critical thresholds in Europe: Status Report 1997. RIVM Rep. 259101007. Bilthoven, The Netherlands. $163 \mathrm{pp}$.

Saffran, K. A. and Trew, D. O. 1996. Sensitivity of Alberta lakes to acidifying deposition: an update of sensitivity maps with emphasis on 109 northern lakes. Water Sciences Branch, Water Management Division, Alberta Environmental Protection. 70 pp.

Schindler, D.G. 1996. The response of aquatic systems in Alberta to acidifying emissions. Final report of the Target Loading Subgroup. Edmonton, Alberta. 47 pp. 
Soil Classification Working Group. 1998. The Canadian system of soil classification. Third Edition. Agriculture and Agri-Food Canada Publication 1646. NRC Research Press, Ottawa. $187 \mathrm{pp}$.

Strong, W., B.K. Calverley, A.J. Richard and G.R. Stewart. 1993. Characterization of wetlands in the settled areas of Alberta. Prepared for Wetlands Management Steering Committee. Alberta Water Resources Commission, Alberta Environmental Protection, Alberta Agriculture, Food and Rural Development, Alberta Municipal Affairs, and Alberta Transportation and Utilities. Edmonton.

Strong W.L. and J.M. Thompson. 1995. Ecodistricts of Alberta : Summary of biophysical attributes. Prep. for Alberta Environmental Protection, Resource Data Division. Publ. No. T/319. Edmonton.

Sverdrup, H. 1990. The kinetics of base cation release due to chemical weathering. Lund University Press. Lund, Sweden. 246 pp.

Sverdrup, H. and P. Warfvinge. 1988. Assessment of critical loads of acid deposition on forest soils. Pages 81-130 in J. Nilsson (ed.) Critical loads for sulphur and nitrogen. Nordic Council of Ministers and The United Nations Economic Commission for Europe (ECE).

Sverdrup, H. and W. de Vries. 1994. Calculating critical loads for acidity with the simple mass balance method. Water, Air and Soil Pollut. 72: 143-162.

Sverdrup, H., W. de Vries and A. Henriksen. 1990. Mapping critical loads - Guidance to criteria, methods and examples for mapping critical loads and areas where they have been exceeded. Task Force on mapping, with the assistance of The United Nations Economic Commission for Europe, Bad Harzburg, FRG. 124 pp.

Sverdrup, H. and P. Warfvinge. 1993. The effect of soil acidification on the growth of trees, grass and herbs as expressed by the $(\mathrm{Ca}+\mathrm{Mg}+\mathrm{K}) / \mathrm{Al}$ ratio. Reports in Ecology and Environmental Engineering: 2. Lund University. 108 pp.

Tajek, J., W.W. Pettapiece and K.E. Toogood. 1989. Water supplying capacity of Alberta soils. Alberta Institute of Pedology Publ. M-89-2. Edmonton. Land Resource Research Centre Publ. 89-117. 24 pp.

Task Force on Mapping. 1996. Manual on mapping critical levels/loads and geographical areas where they are exceeded. UN/ECE Convention on Long-Range Transboundary Air Pollution. Federal Environment Agency (Umweltbundesamt), Berlin. 142 pp. + Appendices.

Task Force on Modelling and Mapping. 2004. Manual on methodologies and criteria for modelling and mapping critical loads and levels and air pollution effects, risks and trends. UNECE Convention on Long-Range Transboundary Air Pollution. Available at: http://www.icpmapping.org. 
Turchenek, L.W. and S.A. Abboud. 1988. Application of a computer simulation model to determination of target loadings for acid deposition on soils. Prep. for Research Management Div., Alberta Environment by Alberta Research Council, Edmonton. 86 pp.

Turchenek, L.W. and S.A. Abboud. 2001. Site-specific critical loads of acid deposition on soils in the Provost-Esther area, Alberta. Prep. for Science and Technology Branch, Environmental Sciences Division, Alberta Environment. Calgary, Alberta. 128 pp.

Turchenek, L.W., S.A. Abboud, R. Xie and G. Lutwick. 1994. Acid deposition impacts on Alberta soils: long term response, critical loads and target loading (Year 2 Results). In Acid Deposition Program Progress Reports (1992-93). Section No. 4, pp. 1-72.

Turchenek, L.W., S.A. Abboud, C.J. Tomas, R.J. Fessenden, and N. Holowaychuk. 1987. Effects of acid deposition on soils in Alberta. Prepared for the Acid Deposition Research Program by the Alberta Research Council, Edmonton. ADRP-B-05-87. Calgary, Canada. 202 pp.

Ulrich, B., K.J. Meiwes, N. Konig and P.K. Khanna. 1984. Untersuchungsverfahren und Kriterion zur Bewertung der Versauerung und ihrer Folgen in Waldboden. Forst. u. Holzwirt 39: 278-286.

UBA (Umweltbundesamt). 2004. Manual on methodologies and criteria for modelling and mapping critical loads \& levels and air pollution effects, risks and trends. Umweltbundesamt Texte 52/04, Berlin. Available: www.icpmapping.org

United Nations Economic Commission for Europe (UNECE) Convention on Long-Range Transboundary Air Pollution. 2006. Manual on methods and criteria for harmonized sampling, assessment, monitoring and analysis of the effects of air pollution on forests. Part IIla. Sampling and analysis of soil. International Co-operative Programme on Assessment and Monitoring of Air Pollution Effects on Forests. Available: http://www.icp-forests.org/pdf/Chapt_3a_2006(1).pdf

United States Natural Resources Conservation Service. 1999. Soil taxonomy : a basic system of soil classification for making and interpreting soil surveys, $2^{\text {nd }}$ ed. Prep. by soil survey staff. Agriculture Handbook (United States. Dept. of Agriculture) No. 436. U.S. Dept. of Agriculture, Natural Resources, Washington, DC. 869 pp. Available: http://soils.usda.gov/classification/taxonomy/main.htm

Warfvinge, P. and H. Sverdrup. 1992. Calculating critical loads of acid deposition with PROFILE - a steady-state soil chemistry model. Water, Air and Soil Pollut. 63: 119-143.

WBK \& Associates Inc. 2006. 2004 Acid Deposition Assessment for Alberta - A Report of the Acid Deposition Assessment Group. Alberta Environment. Edmonton, AB. 


\section{APPENDICES}




\section{APPENDIX A: SOIL PROFILE DESCRIPTIONS}




\section{SITE 1}

Location:

Classification:

Subgroup:

Series:

Land System

Landform:

Genetic Material:

Surface Expression:

Drainage/ Perviousness:

Site Features:

Vegetation:

\section{Profile Description:}

LSD 13 - NW 11 - T 51 - R 26 - W4M

Eluviated Dystric Brunisol

Nestow

Graminia Plain

Eolian

Ridged; $10-15 \%$ slopes

Rapidly drained; high perviousness

Southeast aspect; non-stony

Aspen with a few old jack pine trees; wild rose, green alder, grasses, wintergreen, other forbs

\begin{tabular}{|l|l|l|}
\hline LFH & $4-0 \mathrm{~cm}$ & Newly fallen aspen leaves over moderately decomposed litter \\
\hline Ahe & $0-6 \mathrm{~cm}$ & $\begin{array}{l}\text { Dark grayish brown (10YR 4/2 dry); sand; single grain to weak granular; very } \\
\text { friable to loose; abundant, fine roots; no coarse fragments }\end{array}$ \\
\hline $\mathrm{Ae}$ & $6-16 \mathrm{~cm}$ & $\begin{array}{l}\text { Grayish brown (10YR 5/2 dry); loamy sand; single grain; loose; plentiful fine } \\
\text { roots; no coarse fragments }\end{array}$ \\
\hline $\mathrm{Bm}$ & $16-30+\mathrm{cm}$ & $\begin{array}{l}\text { Brown (10YR 5/3 dry); loamy sand; single grain; loose; few fine roots; no coarse } \\
\text { fragments }\end{array}$ \\
\hline
\end{tabular}

\section{SITE 2}

\section{Location:}

Classification:

Subgroup:

Series:

Land System

Landform:

Genetic Material:

Surface Expression:

Drainage/ Perviousness:

Site Features:

Vegetation:

\section{Profile Description:}

\begin{tabular}{|l|l|l|}
\hline LFH & $8-0 \mathrm{~cm}$ & Newly fallen leaves over moderately decomposed litter \\
\hline Ahe & $0-2 \mathrm{~cm}$ & $\begin{array}{l}\text { Dark gray (10YR 4.5/1 dry); loamy fine sand; single grain to weak granular; very } \\
\text { friable to loose; abundant, fine roots; no coarse fragments }\end{array}$ \\
\hline $\mathrm{Ae}$ & $2-9 \mathrm{~cm}$ & $\begin{array}{l}\text { Grayish brown (10YR 5/2 dry); loamy fine sand; single grain; loose; plentiful fine } \\
\text { roots; no coarse fragments }\end{array}$ \\
\hline $\mathrm{AB}$ & $9-20 \mathrm{~cm}$ & $\begin{array}{l}\text { Brown (10YR 5/3 dry); loamy fine sand; single grain; loose; few fine roots; no } \\
\text { coarse fragments }\end{array}$ \\
\hline $\mathrm{Bm}$ & $20-30+\mathrm{cm}$ & $\begin{array}{l}\text { Pale brown (10YR 5.5/3 dry); loamy fine sand; single grain; loose; very few roots; } \\
\text { no coarse fragments }\end{array}$ \\
\hline
\end{tabular}




\section{SITE 3}

Location:

Classification:

Subgroup:

Series:

Land System

Landform:

Genetic Material:

Surface Expression:

Drainage/ Perviousness:

Site Features:

Vegetation:
LSD 5 - NW 21 - T 51 - R 27 - W4M

Dark Gray Chernozem

Helliwell

Graminia Plain

Glaciofluvial; possibly reworked by wind

Undulating; 3-5\% slopes

Rapidly drained; high perviousness

Northeast aspect; mid slope position; non-stony

Aspen; dense shrub understory with some forbs

\section{Profile Description:}

\begin{tabular}{|l|l|l|}
\hline $\mathrm{LFH}$ & $5-0 \mathrm{~cm}$ & Newly fallen leaves over moderately decomposed litter \\
\hline $\mathrm{Ah}$ & $0-12 \mathrm{~cm}$ & $\begin{array}{l}\text { Dark gray (10YR 4/1 dry); loamy sand; single grain to weak granular; very friable } \\
\text { to loose; abundant, fine roots; no coarse fragments }\end{array}$ \\
\hline $\mathrm{Ae}$ & $12-21 \mathrm{~cm}$ & $\begin{array}{l}\text { Light brownish gray (10YR 6/2 dry); loamy sand; single grain; loose; plentiful fine } \\
\text { roots; no coarse fragments }\end{array}$ \\
\hline $\mathrm{Bm}$ & $21-30+\mathrm{cm}$ & $\begin{array}{l}\text { Pale brown (10YR 5.5/3 dry); loamy sand; single grain; loose; very few roots; no } \\
\text { coarse fragments }\end{array}$ \\
\hline
\end{tabular}

\section{Site 4}

Location:

Classification:

Subgroup:

Series:

Land System

Landform:

Genetic Material:

Surface Expression:

Drainage/ Perviousness:

Site Features:

Vegetation:
LSD 9 - NE $24-$ T $55-$ R $1-$ W5M

Dark Gray Luvisol

Uncas

George Lake Plain

Glacial till

Undulating to hummocky; 6-9\% slopes

Moderately well drained; medium perviousness

Southwest aspect; mid slope position; moderately stony

Aspen; dense shrub (rose and green alder) understory with some forbs

\section{Profile Description:}

\begin{tabular}{|l|l|l|}
\hline LFH & $4-0 \mathrm{~cm}$ & Newly fallen leaves over moderately decomposed litter \\
\hline Ah & $0-8 \mathrm{~cm}$ & $\begin{array}{l}\text { Dark gray (10YR 4/1 dry); loamy sand to sandy loam; medium granular; very } \\
\text { friable; abundant, fine roots; few coarse fragments }\end{array}$ \\
\hline $\mathrm{Ae}$ & $8-32 \mathrm{~cm}$ & $\begin{array}{l}\text { Gray to light gray (10YR 6/1 dry); sandy loam to loam; strong, medium platy; } \\
\text { friable; plentiful fine roots; few coarse fragments }\end{array}$ \\
\hline $\mathrm{Bt}$ & $32+\mathrm{cm}$ & $\begin{array}{l}\text { Dark brown (10YR 4/3 dry); clay loam; moderate, medium subangular blocky; } \\
\text { firm; very few roots; few coarse fragments }\end{array}$ \\
\hline
\end{tabular}




\section{SITE 5}

Location:

Classification:

Subgroup:

Series:

Land System

Landform:

Genetic Material:

Surface Expression:

Drainage/ Perviousness:

Site Features:

Vegetation:
LSD 14 - NW 12 - T 52 - R 21 - W4M

Dark Gray Luvisol

Uncas

Islet Upland

Glacial till

Hummocky; $15-20 \%$ slopes

Well drained; medium perviousness

West aspect; mid slope position; moderately stony

Aspen; some white spruce; dense shrub understory (rose, green alder, cranberry); wintergreen; some forbs

\section{Profile Description:}

\begin{tabular}{|c|c|c|}
\hline LFH & $6-0 \mathrm{~cm}$ & Newly fallen leaves over moderately decomposed litter \\
\hline Ah & $0-4 \mathrm{~cm}$ & $\begin{array}{l}\text { Dark gray (10YR 4/1 dry); sandy loam to loam; granular; very friable; abundant, } \\
\text { fine roots; few coarse fragments }\end{array}$ \\
\hline Ahe & $4-13 \mathrm{~cm}$ & $\begin{array}{l}\text { Gray (10YR } 5 / 1 \text { dry); sandy loam to loam; weak platy; very friable; plentiful fine } \\
\text { roots; few coarse fragments }\end{array}$ \\
\hline $\mathrm{Ae}$ & $13-25 \mathrm{~cm}$ & $\begin{array}{l}\text { Light brownish gray (10YR } 6.5 / 2 \text { dry); sandy loam; moderate, medium platy; very } \\
\text { friable; plentiful fine roots; few coarse fragments }\end{array}$ \\
\hline $\mathrm{Bt}$ & $25-30+\mathrm{cm}$ & $\begin{array}{l}\text { Brown (10YR } 5 / 3 \text { dry); clay loamy; moderate, medium subangular blocky; firm; } \\
\text { few roots; few coarse fragments }\end{array}$ \\
\hline
\end{tabular}

\section{Site 6}

Location:

Classification:

Subgroup:

Series:

Land System

Landform:

Genetic Material:

Surface Expression:

Drainage/ Perviousness:

Site Features:

Vegetation:
LSD $3-$ SW $19-$ T $52-R 20-$ W4M

Orthic Gray Luvisol

Cooking Lake

Islet Upland

Glacial till

Undulating to hummocky; $6-9 \%$ slopes

Moderately well drained; medium perviousness

West aspect; mid slope position; moderately stony

Aspen; dense shrub understory with some forbs; some grassy patches

\section{Profile Description:}

\begin{tabular}{|l|l|l|}
\hline LFH & $10-0 \mathrm{~cm}$ & Newly fallen leaves over moderately decomposed litter \\
\hline Ahe & $0-2 \mathrm{~cm}$ & $\begin{array}{l}\text { Dark gray (10YR 4/1 dry); sandy loam; medium platy; very friable; abundant, fine } \\
\text { roots; few coarse fragments }\end{array}$ \\
\hline $\mathrm{Ae}$ & $2-27 \mathrm{~cm}$ & $\begin{array}{l}\text { Light brownish gray (10YR 6/2 dry); sandy loam; strong, medium platy; friable; } \\
\text { plentiful fine roots; few coarse fragments }\end{array}$ \\
\hline $\mathrm{Bt}$ & $32+\mathrm{cm}$ & Dark brown (10YR 4/3 dry); clay loam; moderate, medium subangular blocky \\
\hline
\end{tabular}




\section{SITE 7}

\section{Location:}

Classification:

Subgroup:

Series:

Land System

Landform:

Genetic Material:

Surface Expression:

Drainage/ Perviousness:

Site Features:

Vegetation:
LSD 16 - NE $34-$ T $52-$ R $21-$ W4M

Orthic Gray Luvisol

Cooking Lake

Islet Upland

Glacial till

Hummocky; $15-20 \%$ slopes

Well drained; medium perviousness

Northwest aspect; mid slope position; moderately stony

Aspen; dense shrub understory; sparse ground vegetation

\section{Profile Description:}

\begin{tabular}{|l|l|l|}
\hline LFH & $12-0 \mathrm{~cm}$ & Newly fallen leaves over moderately decomposed litter \\
\hline Ahe & $0-3 \mathrm{~cm}$ & $\begin{array}{l}\text { Dark gray (10YR 4/1 dry); sandy loam; granular; very friable; abundant, fine } \\
\text { roots; few coarse fragments }\end{array}$ \\
\hline $\mathrm{Ae}$ & $3-22 \mathrm{~cm}$ & $\begin{array}{l}\text { Light brownish gray (10YR 6/2 dry); sandy loam; moderate, medium platy; very } \\
\text { friable; plentiful fine roots; few coarse fragments }\end{array}$ \\
\hline $\mathrm{AB}$ & $22-25 \mathrm{~cm}$ & $\begin{array}{l}\text { Grayish brown (10YR 5.5/3 dry); loam; moderate, medium subangular blocky; } \\
\text { friable; plentiful fine roots; few coarse fragments }\end{array}$ \\
\hline $\mathrm{Bt}$ & $25+\mathrm{cm}$ & $\begin{array}{l}\text { Brown (10YR 5/3 dry); clay loamy; moderate, medium subangular blocky; firm; } \\
\text { few roots; few coarse fragments }\end{array}$ \\
\hline
\end{tabular}

\section{Site 8}
Location:
LSD 9 - NE $36-$ T $49-$ R $21-$ W4M
Classification:
Subgroup:
Orthic Gray Luvisol
Series:
Land System
Landform:
Genetic Material:
Surface Expression:
Cooking Lake
Islet Upland
Glacial till
Undulating to hummocky; 6-9\% slopes
Drainage/ Perviousness:
Site Features:
Vegetation:
Moderately well drained; medium perviousness
Southwest aspect; mid slope position; moderately stony
Aspen; dense shrub understory with some forbs; some grassy patches

\section{Profile Description:}

\begin{tabular}{|l|l|l|}
\hline $\mathrm{LFH}$ & $12-0 \mathrm{~cm}$ & Newly fallen leaves over moderately decomposed litter \\
\hline $\mathrm{Ae}$ & $0-28 \mathrm{~cm}$ & $\begin{array}{l}\text { Light brownish gray (10YR 6/2 dry); sandy loam; moderate, medium platy; friable; } \\
\text { plentiful fine roots; few coarse fragments }\end{array}$ \\
\hline $\mathrm{Bt}$ & $28+\mathrm{cm}$ & Brown (10YR 5/3 dry); clay loam; moderate, medium subangular blocky \\
\hline
\end{tabular}




\section{SITE 9}

Location:

Classification:

Subgroup:

Series:

Land System

Landform:

Genetic Material:

Surface Expression:

Drainage/ Perviousness:

Site Features:

Vegetation:
LSD 16 - NE 11 - T 50 - R 21 - W4M

Orthic Gray Luvisol

Cooking Lake

Islet Upland

Glacial till

Undulating to hummocky; $6-9 \%$ slopes; steep breaks to wetlands adjacent

Well drained; medium perviousness

Southwest aspect; mid slope position; moderately stony

Aspen; shrubs; some forbs; somewhat open canopy

\section{Profile Description:}

\begin{tabular}{|l|l|l|}
\hline LFH & $8-0 \mathrm{~cm}$ & Newly fallen leaves over moderately decomposed litter \\
\hline $\mathrm{Ae}$ & $0-20 \mathrm{~cm}$ & $\begin{array}{l}\text { Light brownish gray (10YR 6/2 dry); sandy loam; moderate, medium platy; friable; } \\
\text { plentiful fine roots; few coarse fragments }\end{array}$ \\
\hline $\mathrm{AB}$ & $20-24 \mathrm{~cm}$ & $\begin{array}{l}\text { Grayish brown (10YR 5/2 dry); loam to clay loam; weak medium, subangular } \\
\text { blocky; friable; plentiful fine roots; plentiful coarse fragments (pebbles, small } \\
\text { stones) }\end{array}$ \\
\hline $\mathrm{Bt}$ & $24-30+\mathrm{cm}$ & $\begin{array}{l}\text { Brown (10YR 5/3 dry); clay loam; moderate, medium subangular blocky; firm; few } \\
\text { roots; plentiful coarse fragments (pebbles, small stones) }\end{array}$ \\
\hline
\end{tabular}

Site 10

Location:

Classification:

Subgroup:

Series:

Land System

Landform:

Genetic Material:

Surface Expression:

Drainage/ Perviousness:

Site Features:

Vegetation:
LSD 13 - NW $34-$ T $50-$ R 21 - W4M

Orthic Gray Luvisol

Cooking Lake

Islet Upland

Glacial till

Undulating; $2-5 \%$ slopes

Moderately well drained; medium perviousness

East aspect; mid slope position; slightly stony

Aspen with some white spruce; dense shrub understory; some forbs

\section{Profile Description:}

\begin{tabular}{|l|l|l|}
\hline LFH & $10-0 \mathrm{~cm}$ & Newly fallen leaves over moderately decomposed litter \\
\hline Ahe & $0-3 \mathrm{~cm}$ & $\begin{array}{l}\text { Dark gray (10YR 4/1 dry); sandy loam; medium platy; very friable; abundant, fine } \\
\text { roots; few coarse fragments }\end{array}$ \\
\hline $\mathrm{Ae}$ & $3-25 \mathrm{~cm}$ & $\begin{array}{l}\text { Grayish brown (10YR 5/2 dry); sandy loam; moderate, medium platy; friable; } \\
\text { plentiful fine roots; few coarse fragments }\end{array}$ \\
\hline $\mathrm{Bt}$ & $25-30+\mathrm{cm}$ & Brown (10YR 4.5/3 dry); clay loam; moderate, medium subangular blocky \\
\hline
\end{tabular}




\section{SITE11}

\section{Location:}

Classification:

Subgroup:

Series:

Land System

Landform:

Genetic Material:

Surface Expression:

Drainage/ Perviousness:

Site Features:

Vegetation:
LSD 9 - NE $23-$ T $56-$ R 21 - W4M

Eluviated Dystric Brunisol

Nestow

Redwater Plain

Eolian (wind reworked glaciofluvial)

Undulating to hummocky; $6-9 \%$ slopes

Rapidly drained; high perviousness

Southwest aspect; lower slope position; non stony

Jack pine/aspen; few shrubs; patchy grasses, lichens; few forbs

\section{Profile Description:}

\begin{tabular}{|l|l|l|}
\hline LF & $2-0 \mathrm{~cm}$ & Pine needles, lichens and grass litter \\
\hline Ahe & $0-7 \mathrm{~cm}$ & $\begin{array}{l}\text { Dark gray (10YR 4.5/1 dry); sand; single grain; loose; plentiful fine roots; no } \\
\text { coarse fragments }\end{array}$ \\
\hline $\mathrm{Ae}$ & $7-18 \mathrm{~cm}$ & $\begin{array}{l}\text { Pale brown (10YR 6/3 dry); sand; single grain; loose; plentiful fine roots; no } \\
\text { coarse fragments }\end{array}$ \\
\hline $\mathrm{Bm}$ & $18-30+\mathrm{cm}$ & $\begin{array}{l}\text { Yellowish brown (10YR 5/4 dry); sand; single grain; loose; few fine roots; no } \\
\text { coarse fragments }\end{array}$ \\
\hline
\end{tabular}

\section{Site 12}

Location:

Classification:

Subgroup:

Series:

Land System

Landform:

Genetic Material:

Surface Expression:

Drainage/ Perviousness:

Site Features:

Vegetation:
LSD 1 - NE 15 - T 57 - R 21 - W4M

Eluviated Dystric Brunisol

Nestow

Redwater Plain

Eolian (wind reworked glaciofluvial)

Undulating to ridged; 6-9\% slopes

Rapidly drained; high perviousness

East aspect; mid slope position; slightly stony

Forage; mostly grasses, minor legumes

\section{Profile Description:}

\begin{tabular}{|l|l|l|}
\hline $\mathrm{Ap}$ & $0-15 \mathrm{~cm}$ & $\begin{array}{l}\text { Grayish brown to light brownish gray (10YR 5/2 and 6/2 dry); sand to sandy loam; } \\
\text { single grain; loose; abundant, fine roots; no coarse fragments }\end{array}$ \\
\hline $\mathrm{Bm}$ & $15-30+\mathrm{cm}$ & Brown (10YR 5/3 dry); sand; single grain; loose; very few roots \\
\hline
\end{tabular}




\section{SITE 13}

\section{Location:}

Classification:

Subgroup:

Series:

Land System

Landform:

Genetic Material:

Surface Expression:

Drainage/ Perviousness:

Site Features:

Vegetation:
LSD 13 - NW 19 - T 57 - R 20 - W4M

Eluviated Dystric Brunisol

Nestow

Eldorena Plain

Eolian

Hummocky to ridged; $10-15 \%$ slopes

Rapidly drained; high perviousness

South aspect; upper slope position; non stony

Jack pine; bearberry; lichens; some grasses; few forbs

\section{Profile Description:}

\begin{tabular}{|l|l|l|}
\hline LF & $4-0 \mathrm{~cm}$ & Pine needle - lichen litter \\
\hline Ahe & $0-2 \mathrm{~cm}$ & $\begin{array}{l}\text { Gray (10YR 5/1 dry); sand; single grain; loose; plentiful fine roots; no coarse } \\
\text { fragments }\end{array}$ \\
\hline $\mathrm{Ae}$ & $2-25 \mathrm{~cm}$ & $\begin{array}{l}\text { Pale brown (10YR 6/3 dry); sand; single grain; loose; plentiful fine roots; no } \\
\text { coarse fragments }\end{array}$ \\
\hline $\mathrm{Bm}$ & $25-30+\mathrm{cm}$ & $\begin{array}{l}\text { Yellowish brown (10YR 5/4 dry); sand; single grain; loose; few fine roots; no } \\
\text { coarse fragments }\end{array}$ \\
\hline
\end{tabular}

\section{SITE 14}

\section{Location:}

Classification:

Subgroup:

Series:

\section{Land System}

Landform:

Genetic Material:

Surface Expression:

Drainage/ Perviousness:

Site Features:

Vegetation:
LSD 3 - SW $3-$ T $57-$ R $22-$ W4M

Eluviated Dystric Brunisol

Nestow

Redwater Plain

Glaciofluvial (surface wind reworked)

Undulating to hummocky; $6-9 \%$ slopes

Rapidly drained; high perviousness

West aspect; mid slope position; non stony

Jack pine; some white spruce and aspen; few shrubs; grasses, lichens; few forbs

\section{Profile Description:}

\begin{tabular}{|l|l|l|}
\hline $\mathrm{LF}$ & $<1 \mathrm{~cm}$ & Pine needles, lichens and grass litter \\
\hline $\mathrm{Ae}$ & $0-8 \mathrm{~cm}$ & $\begin{array}{l}\text { Grayish brown (10YR 5/2 dry); sand; single grain; loose; plentiful fine roots; no } \\
\text { coarse fragments }\end{array}$ \\
\hline $\mathrm{Bm}$ & $8-25+\mathrm{cm}$ & $\begin{array}{l}\text { Yellowish brown (10YR 5/4 dry); sand; single grain; loose; few fine roots; no } \\
\text { coarse fragments }\end{array}$ \\
\hline
\end{tabular}




\section{SITE 15}

Location:

Classification:

Subgroup:

Series:

Land System

Landform:

Genetic Material:

Surface Expression:

Drainage/ Perviousness:

Site Features:

Vegetation:
LSD 1 - SE 34 - T 57 - R 1 - W5M

Orthic Gray Luvisol

Cooking Lake

George Lake Plain

Glacial till

Undulating to hummocky; $6-9 \%$ slopes

Well drained; medium perviousness

East aspect; mid slope position; slightly stony

Aspen; dense rose and alder understory; few forbs

Profile Description:

\begin{tabular}{|l|l|l|}
\hline LF & $12-0 \mathrm{~cm}$ & Newly fallen leaves over dense, felty FH layer \\
\hline Ah & $0-1 \mathrm{~cm}$ & Very dark grayish brown (10YR 3/2 dry); loam; granular \\
\hline $\mathrm{Ae}$ & $1-26 \mathrm{~cm}$ & $\begin{array}{l}\text { Light brownish gray (10YR 6/2 dry); loam; moderate, medium platy; friable; } \\
\text { abundant roots; few coarse fragments }\end{array}$ \\
\hline $\mathrm{Bt}$ & $26-30+\mathrm{cm}$ & $\begin{array}{l}\text { Dark brown (10YR 4/3 dry); clay loam; moderate, medium subangular blocky; } \\
\text { firm; few fine roots; few coarse fragments }\end{array}$ \\
\hline
\end{tabular}

SITE 16

Location:

Classification:

Subgroup:

Series:

Land System

Landform:

Genetic Material:

Surface Expression:

Drainage/ Perviousness:

Site Features:

Vegetation:
LSD 13 - NW 12 - T 58 - R 1 - W5M

Orthic Gray Luvisol

Cooking Lake

George Lake Plain

Glacial till

Undulating; $2-5 \%$ slopes

Well drained; medium perviousness

East aspect; mid slope position; slightly stony

Forage; grass/clover mix

\section{Profile Description:}

\begin{tabular}{|l|l|l|}
\hline Ap & $0-25 \mathrm{~cm}$ & Grayish brown (10YR 5/2 dry); very fine sandy loam; granular; friable \\
\hline $\mathrm{Bt}$ & $25-30+\mathrm{cm}$ & $\begin{array}{l}\text { Dark brown (10YR 4/3 dry); loam; moderate, medium subangular blocky; friable; } \\
\text { few fine roots; few coarse fragments }\end{array}$ \\
\hline
\end{tabular}




\section{SITE 17}

Location:

Classification:

Subgroup:

Series:

Land System

Landform:

Genetic Material:

Surface Expression:

Drainage/ Perviousness:

Site Features:

Vegetation:

$$
\text { LSD } 16 \text { - NE } 11 \text { - T } 58 \text { - R } 1 \text { - W5M }
$$

Orthic Gray Luvisol

Cooking Lake

George Lake Plain

Glacial till

Undulating; $2-5 \%$ slopes

Well drained; medium perviousness

West aspect; mid slope position; slightly stony

Aspen; dense rose and alder understory; forbs and grasses

Profile Description:

\begin{tabular}{|l|l|l|}
\hline $\mathrm{LF}$ & $10-0 \mathrm{~cm}$ & Newly fallen leaves over moderately decomposed FH layer \\
\hline $\mathrm{Ae}$ & $0-25 \mathrm{~cm}$ & $\begin{array}{l}\text { Light gray (10YR 6.5/1 dry); loam; moderate, medium platy; friable; abundant } \\
\text { roots; few coarse fragments }\end{array}$ \\
\hline $\mathrm{Bt}$ & $25-30+\mathrm{cm}$ & $\begin{array}{l}\text { Dark brown (10YR 4/3 dry); clay loam; moderate, medium subangular blocky; } \\
\text { firm; few fine roots; few coarse fragments }\end{array}$ \\
\hline
\end{tabular}

\section{SITE 18}

Location:

Classification:

Subgroup:

Series:

Land System

Landform:

Genetic Material:

Surface Expression:

Drainage/ Perviousness:

Site Features:

Vegetation:
LSD $13-N W 19-$ T 52 - R 20 - W4M

Orthic Gray Luvisol

Cooking Lake

Islet Upland

Glacial till

Hummocky; $10-15 \%$ slopes

Well drained; medium perviousness

Southeast aspect; mid slope position; slightly stony

Forage; grass only; not cut or grazed

\section{Profile Description:}

\begin{tabular}{|l|l|l|}
\hline $\mathrm{Ap}$ & $0-25 \mathrm{~cm}$ & Grayish brown (10YR 5/2 dry); loam to very fine sandy loam; granular; friable \\
\hline $\mathrm{AB}$ & & Some remnant AB at base of Ap \\
\hline $\mathrm{Bt}$ & $25-30+\mathrm{cm}$ & $\begin{array}{l}\text { Dark brown (10YR 4/3 dry); clay loam; moderate, medium subangular blocky; } \\
\text { friable; few fine roots; few coarse fragments }\end{array}$ \\
\hline
\end{tabular}




\section{SITE 19}

Location:

Classification:

Subgroup:

Series:

Land System

Landform:

Genetic Material:

Surface Expression:

Drainage/ Perviousness:

Site Features:

Vegetation:
LSD 1 - SE 24 - T 52 - R 21 - W4M

Orthic Gray Luvisol

Cooking Lake

Islet Upland

Glacial till

Hummocky; 6-9, with some $10-15 \%$ slopes

Well drained; medium perviousness

West aspect; mid slope position; slightly stony

Forage; grass only; not cut or grazed; grass headed; not cut or grazed

Profile Description:

\begin{tabular}{|l|l|l|}
\hline Ap/Ae & $0-12 \mathrm{~cm}$ & $\begin{array}{l}\text { Grayish brown (10YR 5/2 dry); loam to silty loam; granular; friable; grass thatch } \\
\text { at surface }\end{array}$ \\
\hline $\mathrm{Ae}$ & $12-21 \mathrm{~cm}$ & $\begin{array}{l}\text { Light brownish gray (10YR 6/2 dry); loam to silty loam; moderate, medium platy; } \\
\text { friable }\end{array}$ \\
\hline $\mathrm{Bt}$ & $21-30+\mathrm{cm}$ & $\begin{array}{l}\text { Dark brown (10YR 4/3 dry); clay loam; moderate, medium subangular blocky; } \\
\text { friable; few fine roots; few coarse fragments }\end{array}$ \\
\hline
\end{tabular}

\section{SITE 20}

\section{Location: \\ Classification: \\ Subgroup: \\ Series: \\ Land System \\ Landform: \\ Genetic Material: \\ Surface Expression: \\ Drainage/ Perviousness: \\ Site Features: \\ Vegetation:}

LSD 12 - SW $30-$ T 56 - R 20 - W4M

Eluviated Dystric Brunisol

Nestow

Redwater Plain

Eolian

Hummocky; $10-15 \%$ slopes

Rapidly drained; high perviousness

South aspect; upper slope position; non stony

Jack pine; bearberry; lichen; some grassy areas

\section{Profile Description:}

\begin{tabular}{|l|l|l|}
\hline LF & $<1-0 \mathrm{~cm}$ & Pine needle - lichen litter \\
\hline Ahe & $0-1 \mathrm{~cm}$ & $\begin{array}{l}\text { Gray (10YR 5/1 dry); sand; single grain; loose; few fine roots; no coarse } \\
\text { fragments }\end{array}$ \\
\hline $\mathrm{Ae}$ & $1-7 \mathrm{~cm}$ & $\begin{array}{l}\text { Pale brown (10YR 6/3 dry); sand; single grain; loose; few fine roots; no coarse } \\
\text { fragments }\end{array}$ \\
\hline $\mathrm{Bm}$ & $7-25+\mathrm{cm}$ & $\begin{array}{l}\text { Yellowish brown (10YR 5/4 dry); sand; single grain; loose; very few roots; no } \\
\text { coarse fragments }\end{array}$ \\
\hline
\end{tabular}




\section{SITE 21}

Location:

Classification:

Subgroup:

Series:

Land System

Landform:

Genetic Material:

Surface Expression:

Drainage/ Perviousness:

Site Features:

Vegetation:
LSD 1 - SE 16 - T 58 - R 23 - W4M

Eluviated Dystric Brunisol

Nestow

Halfway Lake Dunefield

Eolian

Undulating to hummocky; $6-9 \%$ slopes

Rapidly drained; high perviousness

Southwest aspect; upper slope position; non stony

Jack pine (sparse cover); bearberry; lichen; some grassy areas; lightly grazed

Profile Description:

\begin{tabular}{|l|l|l|}
\hline LF & $<1-0 \mathrm{~cm}$ & Pine needle - lichen litter \\
\hline Ahe & $0-4 \mathrm{~cm}$ & $\begin{array}{l}\text { Dark gray (10YR 4/1 dry); sand; single grain; loose; plentiful fine roots; no coarse } \\
\text { fragments }\end{array}$ \\
\hline $\mathrm{Ae}$ & $4-18 \mathrm{~cm}$ & $\begin{array}{l}\text { Brown (10YR 5/3 dry); sand; single grain; loose; few fine roots; no coarse } \\
\text { fragments }\end{array}$ \\
\hline $\mathrm{Bm}$ & $18-25+\mathrm{cm}$ & $\begin{array}{l}\text { Yellowish brown (10YR 5/4 dry); sand; single grain; loose; very few roots; no } \\
\text { coarse fragments }\end{array}$ \\
\hline
\end{tabular}

\section{SITE 22}

Location:

Classification:

Subgroup:

Series:

Land System

Landform:

Genetic Material:

Surface Expression:

Drainage/ Perviousness:

Site Features:

Vegetation:
LSD $12-\mathrm{SW} 30-\mathrm{T} 56-\mathrm{R} 20-\mathrm{W} 4 \mathrm{M}$

Eluviated Dystric Brunisol

Nestow

Halfway Lake Dunefield

Eolian

Undulating to hummocky; $6-9 \%$ slopes

Rapidly drained; high perviousness

Southeast aspect; upper slope position; non stony

Jack pine; bearberry; lichen

Profile Description:

\begin{tabular}{|l|l|l|}
\hline LF & $<1-0 \mathrm{~cm}$ & Pine needle - lichen litter \\
\hline Ahe & $0-6 \mathrm{~cm}$ & $\begin{array}{l}\text { Dark gray (10YR 4/1 dry); sand; single grain; loose; few fine roots; no coarse } \\
\text { fragments }\end{array}$ \\
\hline $\mathrm{Ae}$ & $6-22 \mathrm{~cm}$ & $\begin{array}{l}\text { Pale brown (10YR 6/3 dry); sand; single grain; loose; few fine roots; no coarse } \\
\text { fragments }\end{array}$ \\
\hline $\mathrm{Bm}$ & $22-25+\mathrm{cm}$ & $\begin{array}{l}\text { Yellowish brown (10YR 5/4 dry); sand; single grain; loose; very few roots; no } \\
\text { coarse fragments }\end{array}$ \\
\hline
\end{tabular}




\section{SITE 23}

\section{Location:}

Classification:

Subgroup:

Series:

Land System

Landform:

Genetic Material:

Surface Expression:

Drainage/ Perviousness:

Site Features:

Vegetation:
LSD 16 - NE 33 - T 47 - R $24-$ W4M

Orthic Dark Gray Chernozem

Helliwell

Pipestone Upland

Eolian

Hummocky; $10-15 \%$ slopes; low relief

Rapidly drained; high perviousness

East aspect; mid slope position; non stony

Aspen; shrub understory with dense grass cover;

\section{Profile Description:}

\begin{tabular}{|l|l|l|}
\hline LFH & $8-0 \mathrm{~cm}$ & Newly fallen aspen leaves over moderately decomposed litter \\
\hline $\mathrm{Ah}$ & $0-22 \mathrm{~cm}$ & $\begin{array}{l}\text { Dark gray (10YR 4/1 dry); loamy sand to sand; granular to single grain; very } \\
\text { friable; abundant fine roots; no coarse fragments }\end{array}$ \\
\hline $\mathrm{Bm}$ & $22-25+\mathrm{cm}$ & $\begin{array}{l}\text { Grayish brown (10YR 5/2 dry); loamy sand to sand; single grain; very friable; very } \\
\text { few roots; no coarse fragments }\end{array}$ \\
\hline
\end{tabular}

\section{SITE 24}

$\begin{array}{ll}\text { Location: } & \text { LSD 1-SE 10-T 47 - R 24-W4M } \\ \text { Classification: } & \\ \quad \text { Subgroup: } & \text { Orthic Black Chernozem } \\ \quad \text { Series: } & \text { Peace Hills } \\ \text { Land System } & \text { Pipestone Upland } \\ \text { Landform: } & \\ \quad \text { Genetic Material: } & \text { Eolian } \\ \quad \text { Surface Expression: } & \text { Undulating; 2-5\% slopes } \\ \text { Drainage/ Perviousness: } & \text { Rapidly drained; high perviousness } \\ \text { Site Features: } & \text { Southwest aspect; mid slope position; non stony } \\ \text { Vegetation: } & \text { Aspen (open); dense shrubs and grasses }\end{array}$

Profile Description:

\begin{tabular}{|l|l|l|}
\hline $\mathrm{Ah}$ & $0-40 \mathrm{~cm}$ & $\begin{array}{l}\text { Black (10YR 2.5/1 dry); loamy sand; weak granular; very friable; abundant fine } \\
\text { roots; no coarse fragments }\end{array}$ \\
\hline $\mathrm{Bm}$ & $40+\mathrm{cm}$ & Dark grayish brown to brown; loamy sand \\
\hline
\end{tabular}




\section{SITE 25}

Location:

Classification:

Subgroup:

Series:

Land System

Landform:

Genetic Material:

Surface Expression:

Drainage/ Perviousness:

Site Features:

Vegetation:
LSD 4 - SW 27 - T 46 - R 24-W4M

Orthic Dark Gray Chernozem

Helliwell

Pipestone Upland

Glaciofluvial; may be wind influenced

Hummocky; $16-20 \%$ slopes; some slopes close to $30 \%$

Rapidly drained; high perviousness

North aspect; mid slope position; non stony

Aspen; some white birch; dense shrub understory; no ground cover

\section{Profile Description:}

\begin{tabular}{|l|l|l|}
\hline LFH & $4-0 \mathrm{~cm}$ & Newly fallen aspen leaves over moderately decomposed litter \\
\hline Ahe & $0-25 \mathrm{~cm}$ & $\begin{array}{l}\text { Grayish brown (10YR 4.5/2 dry); sand; single grain; loose; abundant fine roots; } \\
\text { no coarse fragments }\end{array}$ \\
\hline $\mathrm{Ae}$ & $25-35 \mathrm{~cm}$ & $\begin{array}{l}\text { Brown (10YR 5/3 dry); sand; single grain; loose; few fine roots; no coarse } \\
\text { fragments }\end{array}$ \\
\hline $\mathrm{Bm}$ & $35+\mathrm{cm}$ & Brown to yellowish brown; sand \\
\hline
\end{tabular}

\section{SITE 26}

Location:

Classification:

Subgroup:

Series:

Land System

Landform:

Genetic Material:

Surface Expression:

Drainage/ Perviousness:

Site Features:

Vegetation:
LSD $13-$ NW $23-$ T $47-$ R $28-$ W4M

Orthic Gray Luvisol

Breton

Yeoford Plain

Glacial till

Undulating to hummocky; $6-9 \%$ slopes

Well drained; medium perviousness

Northeast aspect; mid slope position; slightly stony

Aspen; dense shrub understory; some forbs

\section{Profile Description:}

\begin{tabular}{|l|l|l|}
\hline LF & $8-0 \mathrm{~cm}$ & Newly fallen leaves over moderately decomposed FH layer \\
\hline Ahe & $0-4 \mathrm{~cm}$ & $\begin{array}{l}\text { Dark gray (10YR 4/1 dry); loam; weak, medium platy; friable; abundant roots; few } \\
\text { coarse fragments }\end{array}$ \\
\hline $\mathrm{Ae}$ & $4-30 \mathrm{~cm}$ & $\begin{array}{l}\text { Light gray (10YR 6.5/2 dry); loam; moderate, medium platy; friable; abundant } \\
\text { roots; few coarse fragments }\end{array}$ \\
\hline $\mathrm{Bt}$ & $30+\mathrm{cm}$ & $\begin{array}{l}\text { Brown (10YR 4.5/3 dry); clay loam; moderate, medium subangular blocky; firm; } \\
\text { few fine roots; few coarse fragments }\end{array}$ \\
\hline
\end{tabular}




\section{SITE 27}

\section{Location:}

Classification:

Subgroup:

Series:

Land System

Landform:

Genetic Material:

Surface Expression:

Drainage/ Perviousness:

Site Features:

Vegetation:
LSD $4-S W 3-$ T $48-$ R $27-$ W4M

Orthic Gray Luvisol

Breton

Falun Plain

Glacial till

Undulating; $2-5 \%$ slopes

Well drained; medium perviousness

Northeast aspect; mid slope position; slightly stony

Aspen; some large white spruce; shrubs; some forbs, grasses

\section{Profile Description:}

\begin{tabular}{|l|l|l|}
\hline LF & $6-0 \mathrm{~cm}$ & Newly fallen leaves over moderately decomposed FH layer \\
\hline Ahe & $0-4 \mathrm{~cm}$ & $\begin{array}{l}\text { Dark gray (10YR 4.5/1 dry); loam to silty loam; weak, medium platy; friable; } \\
\text { abundant roots; few coarse fragments }\end{array}$ \\
\hline $\mathrm{Ae}$ & $4-22 \mathrm{~cm}$ & $\begin{array}{l}\text { Light brownish gray (10YR 6/2 dry); loam to silty loam; moderate, medium platy; } \\
\text { friable; plentiful roots; few coarse fragments }\end{array}$ \\
\hline $\mathrm{Bt}$ & $22-25+\mathrm{cm}$ & $\begin{array}{l}\text { Brown (10YR 4.5/3 dry); clay loam; moderate, medium subangular blocky; firm; } \\
\text { few fine roots; few coarse fragments }\end{array}$ \\
\hline
\end{tabular}




\section{APPENDIX B: SOIL CHEMICAL DATA}




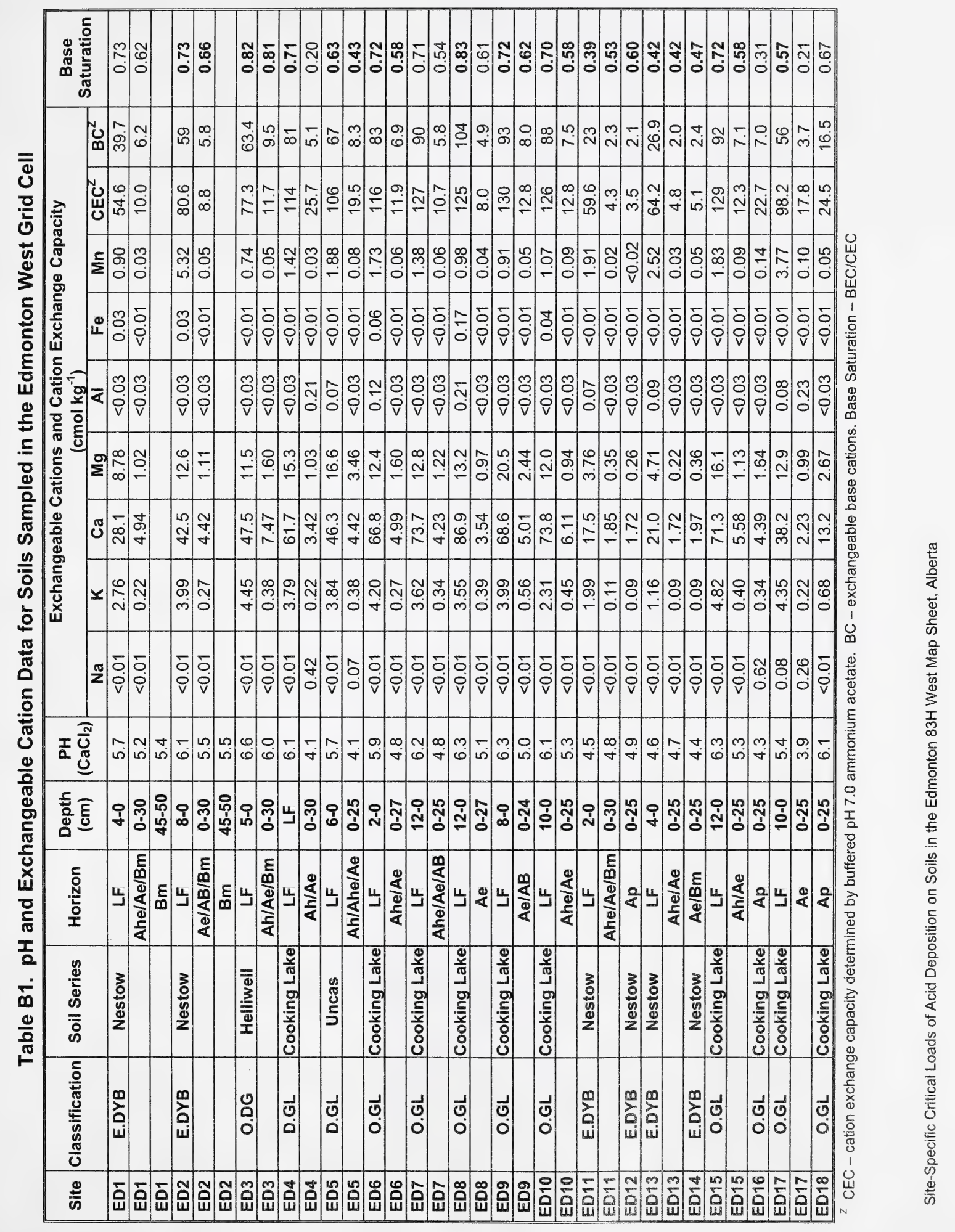




\begin{tabular}{|c|c|c|c|c|c|c|c|c|c|c|c|c|}
\hline 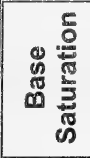 & @̋ & भ̊ & क्ष & 웜 & & : & 足 & $\begin{array}{l}0 \\
0 \\
0 \\
0\end{array}$ & & & & 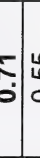 \\
\hline c & טִ & مُ & م & $\underset{\infty}{\infty}$ & $\stackrel{0}{-}$ & $\stackrel{\leftrightarrow}{\stackrel{\leftrightarrow}{*}}$ & $=$ & $\begin{array}{l}0 \\
\infty \\
\infty \\
\end{array}$ & $\left(\begin{array}{c}0 \\
\infty\end{array}\right.$ & & & $\begin{array}{l}\text { ले } \\
\text { eे }\end{array}$ \\
\hline$\frac{\pi}{0}$ & ט. & $\stackrel{\overrightarrow{.}}{\vec{m}}$ & m. & $\begin{array}{l}0 \\
\vdots \\
\grave{N}\end{array}$ & \begin{tabular}{lll}
0 & $s$ \\
& \multirow{c}{c}{}
\end{tabular} & के & $\begin{array}{l}m \\
\text { Dू. }\end{array}$ & ì & $\begin{array}{l}0 \\
\dot{\sim} \\
+\end{array}$ & \begin{tabular}{l|l}
$\infty$ & \\
$\dot{0}$ & \multirow{0}{*}{}
\end{tabular} & ผึ่: & $\bar{i}$ \\
\hline 恿 & $=\int_{0}^{+}$ & 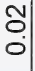 & $\begin{array}{l}\text { ○ิ } \\
0\end{array}$ & $\begin{array}{l}0 \\
0 \\
0 \\
0\end{array}$ & 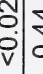 & 웅 & $\begin{array}{l}0 \\
0 \\
0\end{array}$ & $\begin{array}{l}8 \\
\dot{0}\end{array}$ & sin & & $\frac{0}{0}$ & $\begin{array}{c}0 \\
0 \\
0 \\
0\end{array}$ \\
\hline 胥 & $\begin{array}{l}\overline{0} \\
\stackrel{0}{0} \\
\dot{0} \\
\mathrm{v}\end{array}$ & $\begin{array}{l}- \\
\\
\text { v } \\
\text { v }\end{array}$ & $\begin{array}{l}\overline{0} \\
\dot{0} \\
\mathrm{v}\end{array}$ & 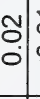 & 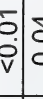 & b & $\begin{array}{l}- \\
0 \\
0 \\
\mathbf{v}\end{array}$ & $\begin{array}{l}5 \\
0 \\
0 \\
\mathrm{v}\end{array}$ & $\begin{array}{l}\text { - } \\
\text { ○े } \\
\text { v }\end{array}$ & & & 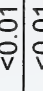 \\
\hline 它 & $=\begin{array}{l}m \\
0 \\
0 \\
\text { v }\end{array}$ & $\begin{array}{l}m \\
0 \\
0 \\
\dot{v}\end{array}$ & $\begin{array}{l}m \\
0 \\
0 \\
0\end{array}$ & & & : & $\begin{array}{l}m \\
0 \\
0 \\
v\end{array}$ & $\begin{array}{l}m \\
\text { ô } \\
0 \\
\text { v }\end{array}$ & 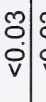 & & & 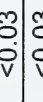 \\
\hline$\stackrel{n}{0}$ & $=\frac{N}{N}$ & ำ & $\frac{\infty}{\circ}$ & $\stackrel{10}{\leftarrow}$ & 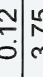 & م. & $\begin{array}{l}\mathcal{Y} \\
\sim \\
\sim\end{array}$ & $\begin{array}{l}\mathbf{5} \\
\infty \\
\infty\end{array}$ & & & & 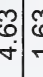 \\
\hline$\frac{0}{\stackrel{0}{\pi}}$ & $\begin{array}{l}0 \\
\end{array}$ & $\stackrel{5}{-}$ & ঙ্লি. & 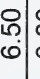 & $\begin{array}{lll} & 0 \\
\infty & 0 & 0 \\
0 & 0\end{array}$ & : & $\stackrel{-}{+}$ & $\begin{array}{l}0 \\
\stackrel{2}{N}\end{array}$ & $\begin{array}{l}\hat{\omega} \\
\dot{0}\end{array}$ & & & : \\
\hline $\begin{array}{l}\text { 胥 } \\
\text { Ũ } \\
\text { w }\end{array}$ & $=$\begin{tabular}{l}
$m$ \\
\multirow{2}{*}{} \\
0
\end{tabular} & 8. & : & స్. & ?.? & $=\frac{\infty}{0}$ & 8 & $\stackrel{\overbrace{}}{\sim}$ & & & & 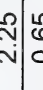 \\
\hline I & $\begin{array}{l}\tilde{O} \\
0 \\
0\end{array}$ & $\begin{array}{l}5 \\
0 \\
0 \\
v\end{array}$ & $\begin{array}{l}- \\
0 \\
0 \\
v\end{array}$ & ర్ & 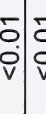 & iे & $\begin{array}{c}\overline{0} \\
\dot{0} \\
\mathrm{v}\end{array}$ & & & & & 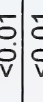 \\
\hline 工 & {$\left[\begin{array}{l}\hat{i} \\
i\end{array}\right.$} & $\stackrel{Y}{+}$ & \begin{tabular}{l|l}
0 \\
$1{ }^{\circ}$
\end{tabular} & $\begin{array}{l}0 \\
+\end{array}$ & \begin{tabular}{l|l|l}
$r$ & 15 \\
$\forall$ & 15
\end{tabular} & $\begin{array}{l}\stackrel{\bullet}{+} \\
\dot{\gamma}\end{array}$ & $\begin{array}{l}N \\
10\end{array}$ & $\ddot{0}$ & $\begin{array}{l}\text { ㅇ․ } \\
\text { | }\end{array}$ & & & \begin{tabular}{c|c}
\multirow{N}{*}{} & 15 \\
& 15
\end{tabular} \\
\hline 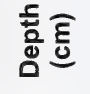 & : & ָุ. & $\begin{array}{l}\text { ஸे } \\
\vdots\end{array}$ & 인 & స్̊ & ஸे & ฟุ & 염 & เి & & & ơ \\
\hline 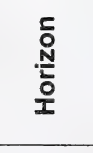 & 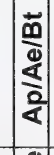 & 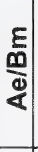 & 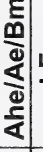 & 4 & | & 旁 & & 岃 & $\frac{9}{4}$ & & 选| & $\frac{T}{4}$ \\
\hline 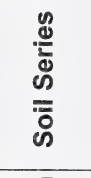 & 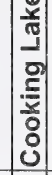 & $\begin{array}{l}3 \\
0 \\
0 \\
\vdots \\
2\end{array}$ & $\begin{array}{l}3 \\
0 \\
0 \\
0 \\
2\end{array}$ & $\begin{array}{l}3 \\
0 \\
\vdots \\
0 \\
z\end{array}$ & 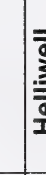 & & 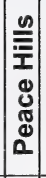 & 离 & & 현 & & 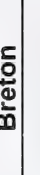 \\
\hline 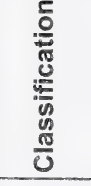 & ए. & 变 & 吝 & Lُ & & & 邑 & $\begin{array}{l}\text { Oे } \\
\text { o. }\end{array}$ & & ర్ & & \begin{tabular}{|}
0 \\
0 \\
0 \\
\end{tabular} \\
\hline$\stackrel{2}{2}$ & 疍 & ס̊ & సั. & & సิำ & ปั่ & 跑 & 诘 & 宊 & 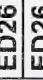 & & \\
\hline
\end{tabular}




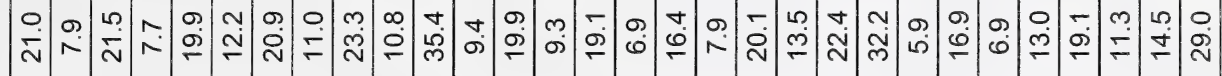

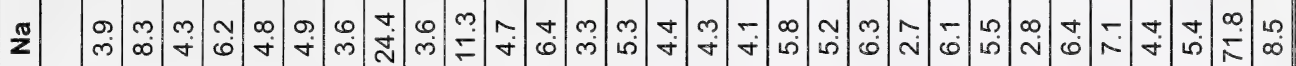

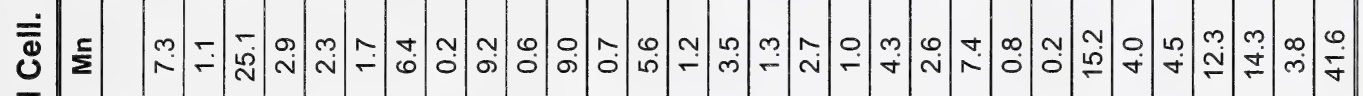

은

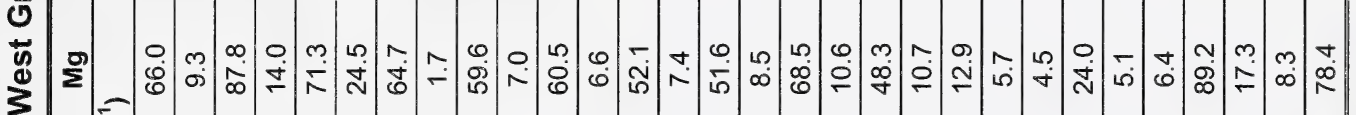

冚

\&)

L L

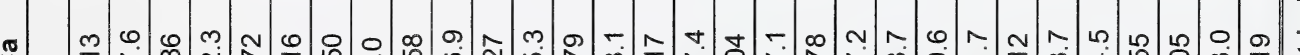

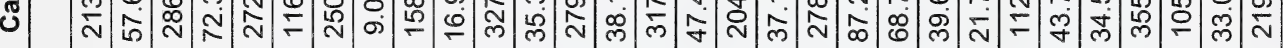

œ

동

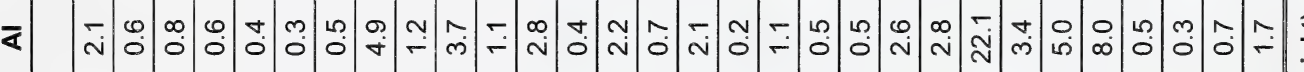

ก

Ш

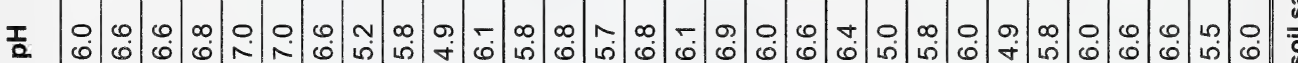

กิ

N

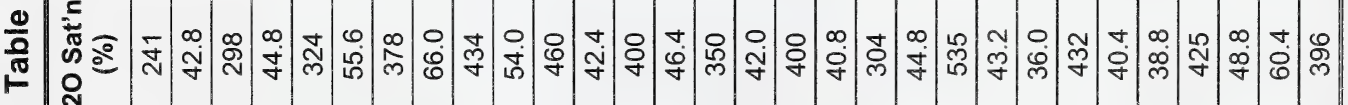
ำ

音

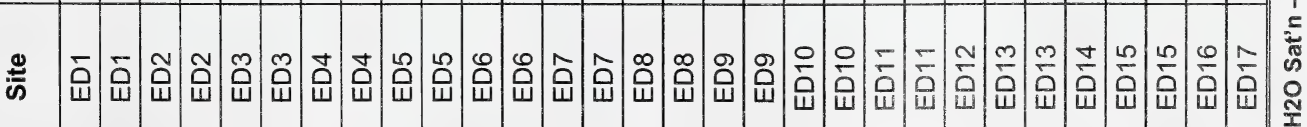




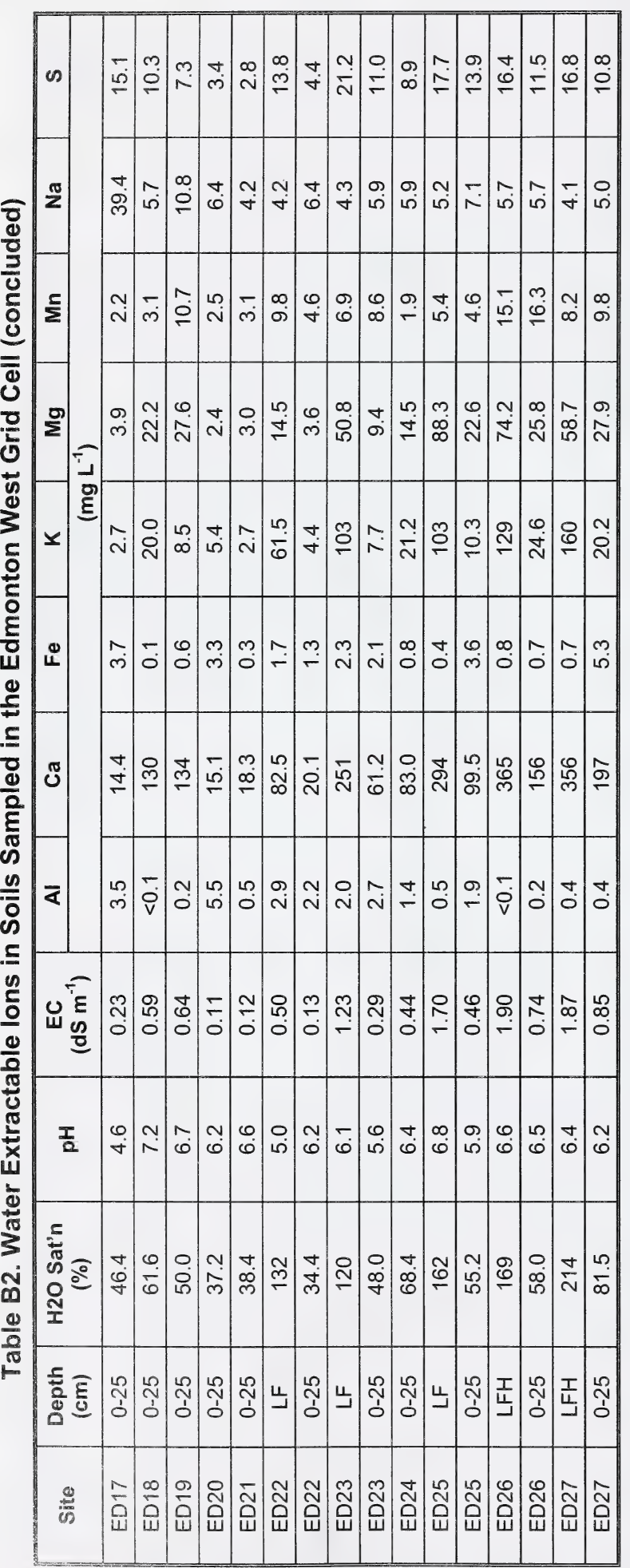




\section{APPENDIX C: AREAS OF LAND SYSTEMS AND LAND COVER TYPES}




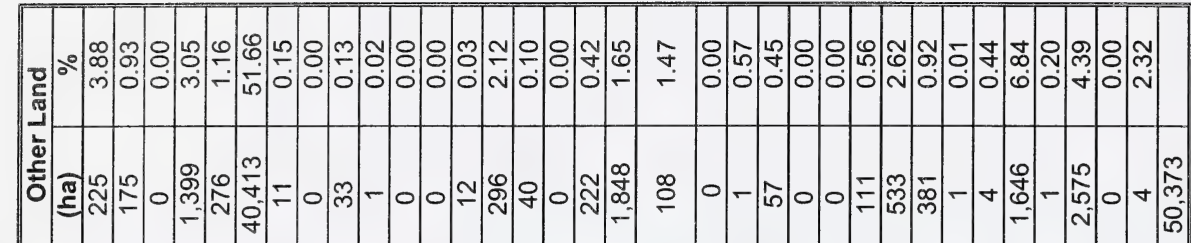

$\bar{\jmath}$

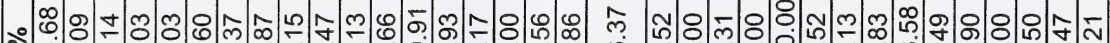
¿্র

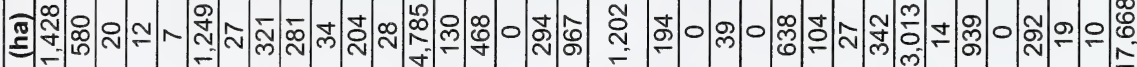

등

๑ ল্

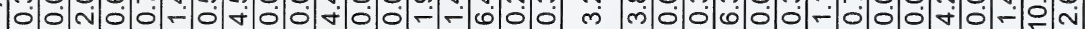

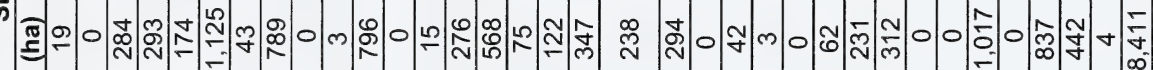

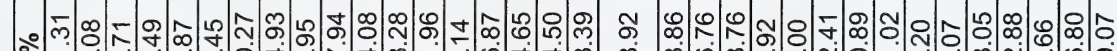
mं o

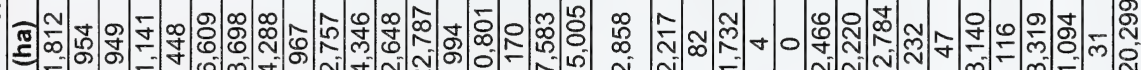

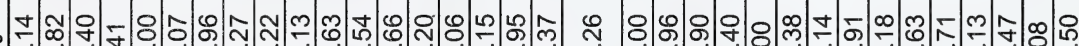
సิ

号

站

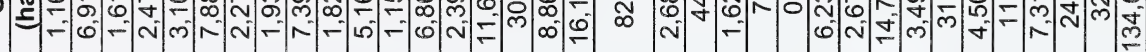

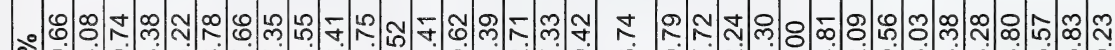
-

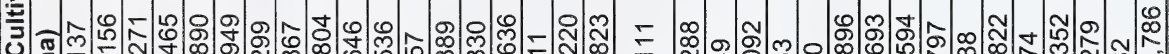
ฐ

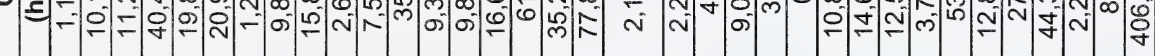

ฮั ๔ ๘ . 은

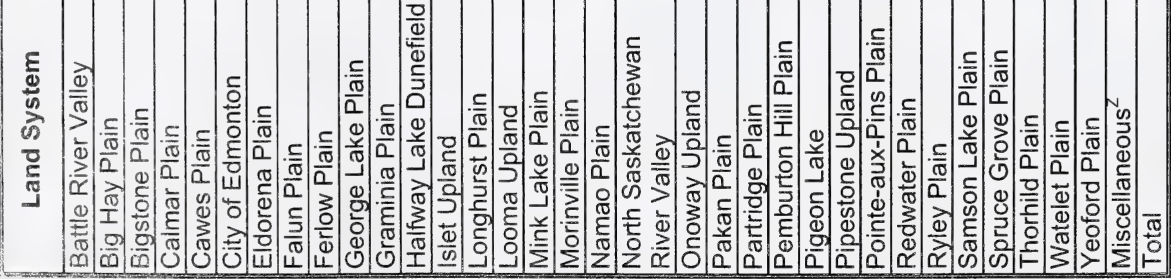


APPENDIX D: LAND AREA ESTIMATION OF SENSITIVITY CLASSES 


\section{LAND AREA ESTIMATION OF SENSITIVITY CLASSES}

Three Land Systems in the Edmonton West grid cell were found to include Soil Series to be Sensitive or Moderately Sensitive to acidification according to the ARC model. The Primula (Eluviated Eutric Brunisol) and Nestow (Eluviated Dystric Brunisol) are considered together as being Sensitive to Moderately Sensitive to acidification. The Helliwell (Orthic Dark Gray Chernozem) and Mundare (Orthic Black Chernozem) Soil Series are rated as being of Moderate to Low sensitivity. The table below indicates the sensitivity classes of these soils, as well their estimated proportions in five Land Systems. The assignment of proportions was as follows:

- Land System with a major soil and two minor soils: the major soil is estimated to constitute $70 \%$ of the Land System, and the minor soils are estimated to constitute $15 \%$ each.

- Land System with two major soil series and two minor soil series: the major soils are estimated to each constitute $35 \%$ of the Land System, and the minor soils are estimated to constitute $15 \%$ each. If water is associated with Organic soils, the ratio is $40-40-20$.

\begin{tabular}{|c|c|c|c|c|c|}
\hline Soil Series & Mundare & $\begin{array}{c}\text { Primula } \\
\text { (Nestow) }\end{array}$ & Peace Hills & Helliwell & $\begin{array}{c}\text { Manatokan, } \\
\text { Misc. Organics }\end{array}$ \\
\hline Series Sensitivity & M-L & S-M & L & M-L & L \\
\hline Redwater Plain & $70 \%$ & $15 \%$ & $15 \%$ & & \\
\hline Eldorena Plain & $15 \%$ & $35 \%$ & $35 \%$ & & $15 \%$ \\
\hline $\begin{array}{c}\text { Halfway Lake } \\
\text { Dunefield }\end{array}$ & & $40 \%$ & & $40 \%$ & $20 \%$ \\
\hline
\end{tabular}

The above percentages of Soil Series in the Land Systems were then compared to the land cover data (Appendix C). It was assumed that the cultivated lands were occupied by the soils with the highest agricultural capability, and that land with shrub, tree and grassland cover would have the sandiest soils, namely Mundare, Helliwell and Primula/Nestow. Also, percent areas of each of the occurrences of Primula//Nestow. Helliwell and Mundare were halved and assigned to two sensitivity classes because of their dual ratings. For example, Primula/Nestow is rated Sensitive to Moderately Sensitive; therefore, half their areas were assigned to each of these sensitivity ratings. Details of the rating derivations are provided below for the five Land Systems with Moderate and Sensitive ratings.

\section{Redwater Plain}

- Cultivated - 31\%; Peace Hills - 15\%; Mundare - 16\%

- Other - 1\%; not rated

- Grassland, Shrubs and Trees - 68\%; 15\% Primula; 53\% Mundare

- Sensitive - Half of Primula (7-8\%)

- Moderate Sensitivity - Half of Primula (7-8\%) and half of Mundare (26\%)

- Low Sensitivity - Half of Mundare (27\%)

- Summary: Sensitive - 7-8\%; Moderate - 33\%; Low - 27\%; Not Rated - 33\% 


\section{Eldorena Plain}

- Cultivated - 18\%; Peace Hills - $18 \%$

- Other - <1\%; not rated

- Grassland, Shrubs and Trees - 82\%; 17\% Peace Hills; 35\% Primula; 15\% Mundare; $15 \%$ Mantokan

- Sensitive - Half of Primula (17-18\%)

- Moderate Sensitivity - Half of Primula (17-18\%) and half of Mundare (7-8\%);

- Low Sensitivity - Half of Mundare (7-8\%), Peace Hills, non-cultivated - 17\%, Manatokan $15 \%$

- Summary: Sensitive - 17-18\%; Moderate - 25\%; Low - 39\%; Not Rated - 19\%

\section{Halfway Lake Dunefield}

- Cultivated - $8 \%$; Helliwell - $9 \%$

- Other - <1\%; not rated

- Organics - $20 \%$

- Grassland, Shrubs and Trees - 71\%; 40\% Primula; 31-32\% Helliwell

- Sensitive - Half of Primula (20\%)

- Moderate Sensitivity - Half of Primula (20\%) and half of Helliwell (16\%)

- Low Sensitivity - Half of Helliwell (16\%); Organics - $20 \%$

- Summary: Sensitive - 20\%; Moderate - 36\%; Low - 36\%; Not Rated - $8 \%$ 
BASELINE SOIL AND TERRAIN MAPS 



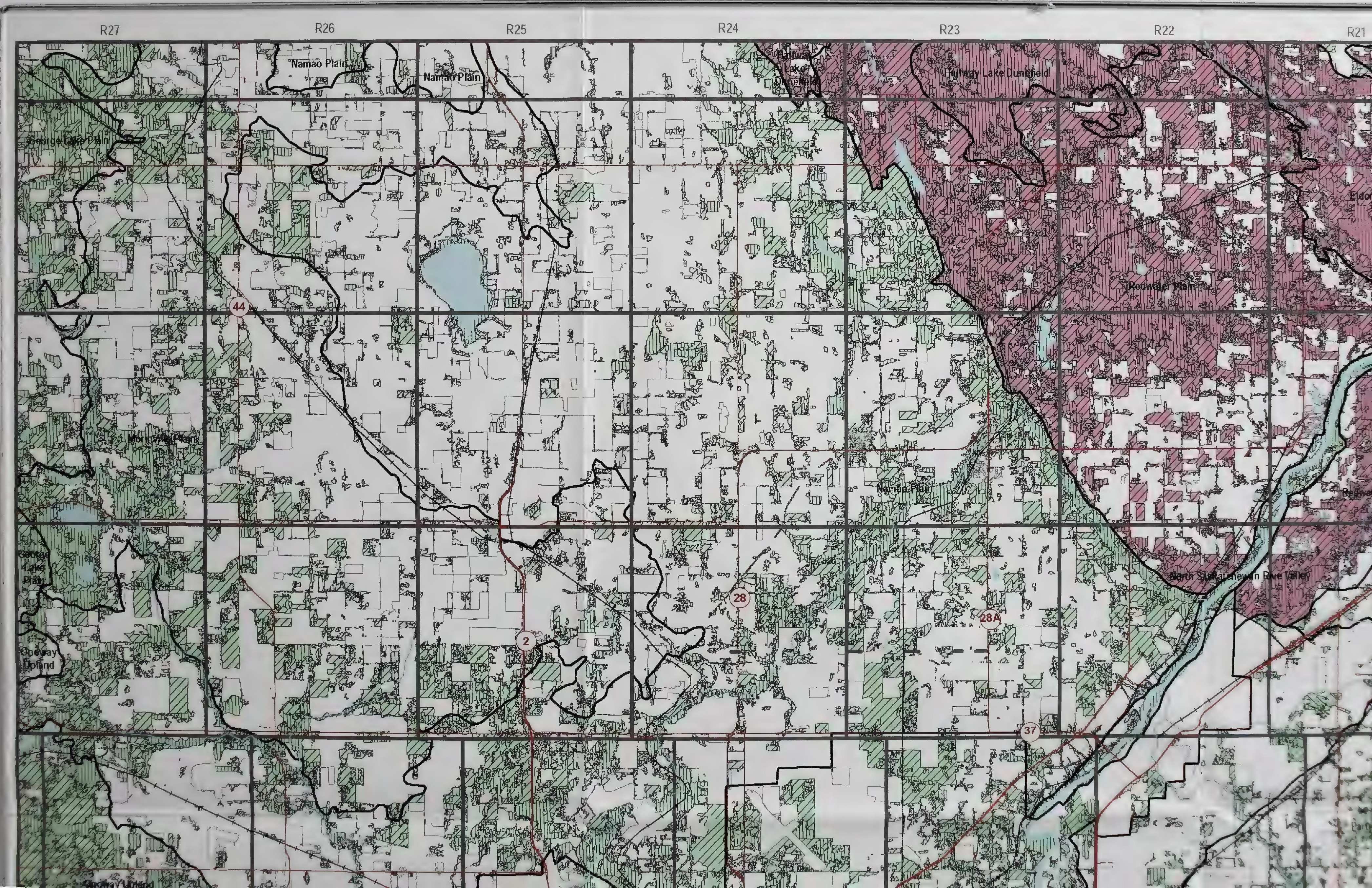




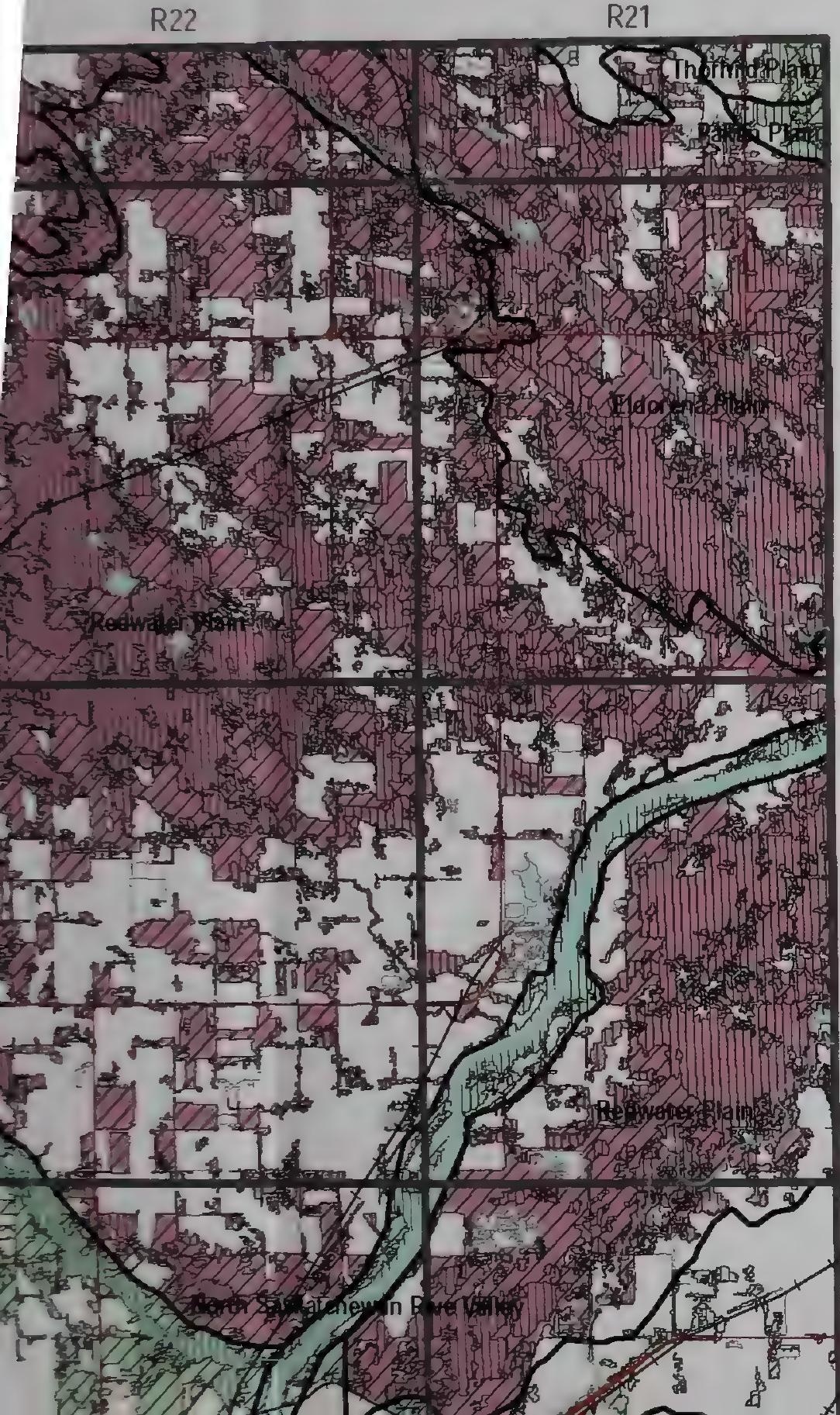

\section{Legend}

T57

T56

\begin{tabular}{|c|c|c|c|}
\hline Land System & Land System Description & Major Solls & Minor Solls \\
\hline $\begin{array}{l}\text { Battle River } \\
\text { Valley } \\
05.00 .09^{z}\end{array}$ & $\begin{array}{l}\text { Valley bottom with some confined floodplain. } \\
\text { Regosols developed on undifferentiated material. } \\
\text { Minor soils include coarse textured soils. Significant } \\
\text { eroded soils present. }\end{array}$ & Miscellaneous Eroded & $\begin{array}{l}\text { Milk River-AA } \\
\text { (Cumulic Regosol) }\end{array}$ \\
\hline $\begin{array}{l}\text { Big Hay Plain } \\
05.3 d .26\end{array}$ & $\begin{array}{l}\text { Undulating landscape with some level- closed basin. } \\
\text { Black Chemozems and Black Solonetz developed on } \\
\text { medium textured till and fine textured water-laid } \\
\text { sediments. Minor soils include Gleysols. }\end{array}$ & $\begin{array}{l}\text { Angus Ridge } \\
\text { (Eluviated Black Chernozem) } \\
\text { Wetaskiwin } \\
\text { (Black Solodized Solonetz) }\end{array}$ & $\begin{array}{l}\text { Malmo } \\
\text { (Eluviated Black Chernozem } \\
\text { GleysoisMater }\end{array}$ \\
\hline $\begin{array}{l}\text { Bigstone Plain } \\
05.3 \mathrm{~d} .30\end{array}$ & $\begin{array}{l}\text { Undulating landscape with some duned. Black } \\
\text { Chernozems developed on coarse textured sediments } \\
\text { and medium textured material over medium textured } \\
\text { till. Minor soils include Gleysols. }\end{array}$ & $\begin{array}{l}\text { Peace Hills } \\
\text { (Orthic Black Chernozem) } \\
\text { Hobberna } \\
\text { (Eluviated Black Chemozem) }\end{array}$ & $\begin{array}{l}\text { Ponoka } \\
\text { (Eluviated Black Chernozem } \\
\text { Gleysols } N \text { ater }\end{array}$ \\
\hline $\begin{array}{l}\text { Calmar Plain } \\
05.3 \mathrm{~d} .21\end{array}$ & $\begin{array}{l}\text { Undulating landscape. Black Chemozems developed } \\
\text { on fine textured water-laid sediments. }\end{array}$ & $\begin{array}{l}\text { Malmo } \\
\text { (Eluviated Black Chernozem) }\end{array}$ & $\begin{array}{l}\text { Ponoka } \\
\text { (Eluviated Black Chernozem } \\
\text { Looma } \\
\text { Orthic Dark Gray Chernozer }\end{array}$ \\
\hline $\begin{array}{l}\text { Cawes Plain } \\
05.3 \text { d.10 }\end{array}$ & $\begin{array}{l}\text { Undulating landscape. Black Chemozems developed } \\
\text { on medium textured till. }\end{array}$ & $\begin{array}{l}\text { Angus Ridge } \\
\text { (Eluviated Black Chemozem) }\end{array}$ & $\begin{array}{l}\text { Hobbema } \\
\text { (Eluviated Black Chernozem } \\
\text { Rolly View } \\
\text { (Orthic Dark Gray Chemozer }\end{array}$ \\
\hline $\begin{array}{l}\text { City of Edmonton } \\
05.3 \mathrm{~d} .14\end{array}$ & City of Edmonton. & Disturbed Lands & \\
\hline $\begin{array}{l}\text { Eldorena Plain } \\
06.2 a .11\end{array}$ & $\begin{array}{l}\text { Undulating landscape with some duned. Black } \\
\text { Chernozems and Brunisols developed on coarse } \\
\text { textured sediments. }\end{array}$ & $\begin{array}{l}\text { Peace Hills } \\
\text { (Orthic Black Chernozem) } \\
\text { Primula } \\
\text { (Eluviated Eutric Brunisol) }\end{array}$ & $\begin{array}{l}\text { Manatokan-AA } \\
\text { (Terric Mesisol) } \\
\text { Mundare } \\
\text { (Orthic Black Chemozem) }\end{array}$ \\
\hline $\begin{array}{l}\text { Falun Plain } \\
06.1 \text { c.12 }\end{array}$ & $\begin{array}{l}\text { Undulating landscape. Dark Gray Luvisols and Dark } \\
\text { Gray Chernozems developed on medium textured till. } \\
\text { Minor soils include Organic. }\end{array}$ & $\begin{array}{l}\text { Benalto } \\
\text { (Dark Gray Luvisol) } \\
\text { Falun } \\
\text { (Orthic Dark Gray Chernozem) }\end{array}$ & $\begin{array}{l}\text { Breton } \\
\text { (Orthic Gray Luvisol) } \\
\text { Organics }\end{array}$ \\
\hline $\begin{array}{l}\text { Ferlow Plain } \\
05.3 \mathrm{~d} .27\end{array}$ & $\begin{array}{l}\text { Hummocky landscape. Biack Chernozems developed } \\
\text { on medium textured till. Minor soils include Gleysols. }\end{array}$ & $\begin{array}{l}\text { Angus Ridge } \\
\text { (Eluviated Black Chernozem) }\end{array}$ & $\begin{array}{l}\text { Rolly View } \\
\text { (Orthic Dark Gray Chemozer } \\
\text { GleysolsNater }\end{array}$ \\
\hline $\begin{array}{l}\text { George Lake } \\
\text { Plain } \\
06.1 d .02\end{array}$ & $\begin{array}{l}\text { Hummocky landscape with some numerous water } \\
\text { bodies. Gray Luvisols and Gray Solonetz developed } \\
\text { on medium textured till. Minor soils include Gleysols. }\end{array}$ & $\begin{array}{l}\text { Cooking Lake } \\
\text { (Orthic Gray Luvisol) } \\
\text { Dnister } \\
\text { (Gray Solodized Solonetz) }\end{array}$ & $\begin{array}{l}\text { Nakamun } \\
\text { (Solonetzic Gray Luvisol) } \\
\text { GleysolsNater }\end{array}$ \\
\hline $\begin{array}{l}\text { Graminia Plain } \\
05.3 \mathrm{~d} .20\end{array}$ & $\begin{array}{l}\text { Undulating landscape with some duned. Dark Gray } \\
\text { Luvisols developed on coarse textured sediments. } \\
\text { Minor soils include Organic. }\end{array}$ & $\begin{array}{l}\text { Elk Point } \\
\text { (Dark gray Luvisol) } \\
\text { Tiger Lily } \\
\text { (Orthic Gray Luvisol) }\end{array}$ & Organics \\
\hline $\begin{array}{l}\text { Halfway Lake } \\
\text { Dunefield }\end{array}$ & $\begin{array}{l}\text { Undulating landscape. Brunisols and Dark Gray } \\
\text { Chernozems developed on coarse textured } \\
\text { sediments. Minor soils include Organic and Gieysols. }\end{array}$ & $\begin{array}{l}\text { Primula } \\
\text { (Eluviated Eutric Brunisol) } \\
\text { Helliwell }\end{array}$ & Gleysols Nater \\
\hline
\end{tabular}




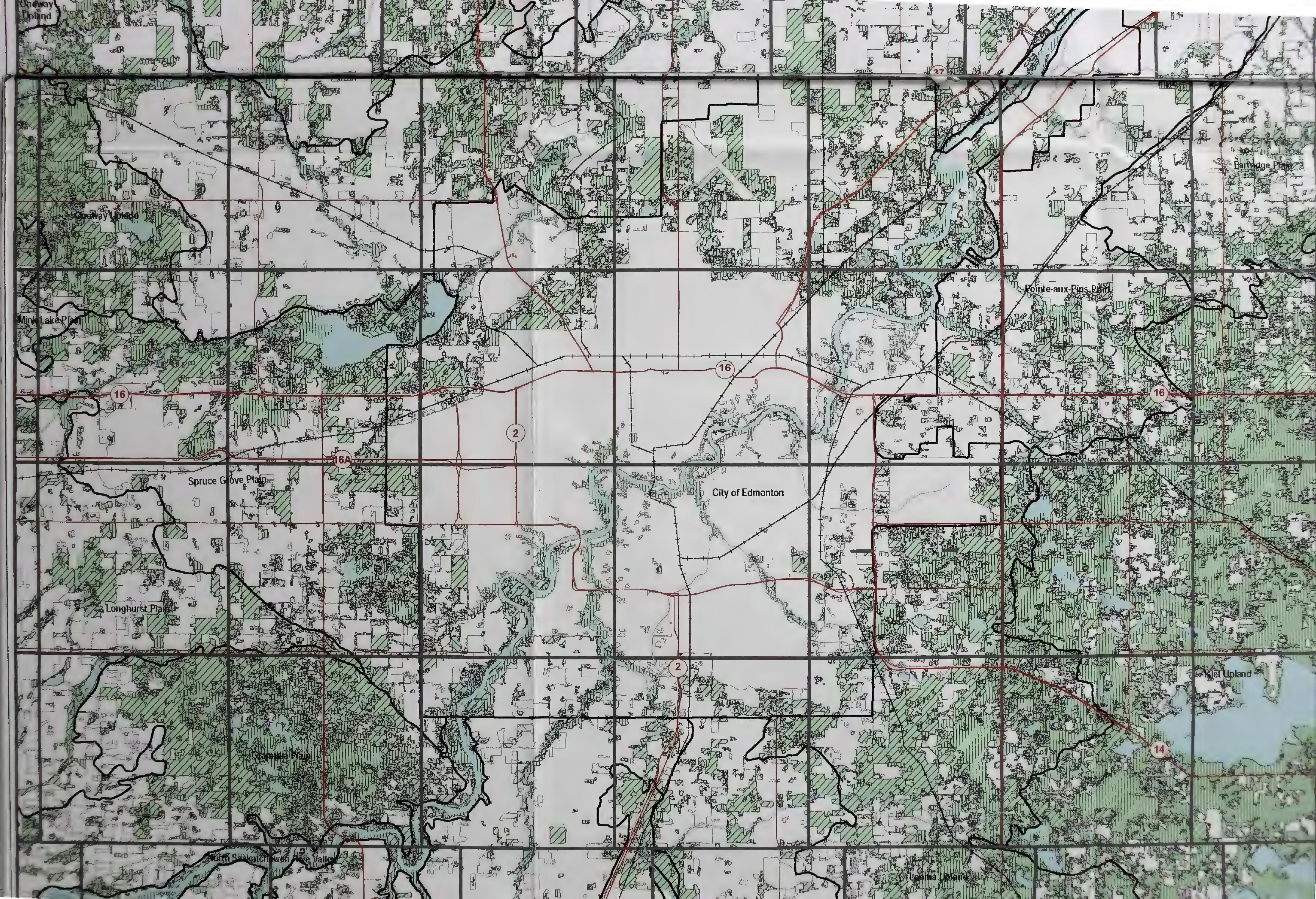




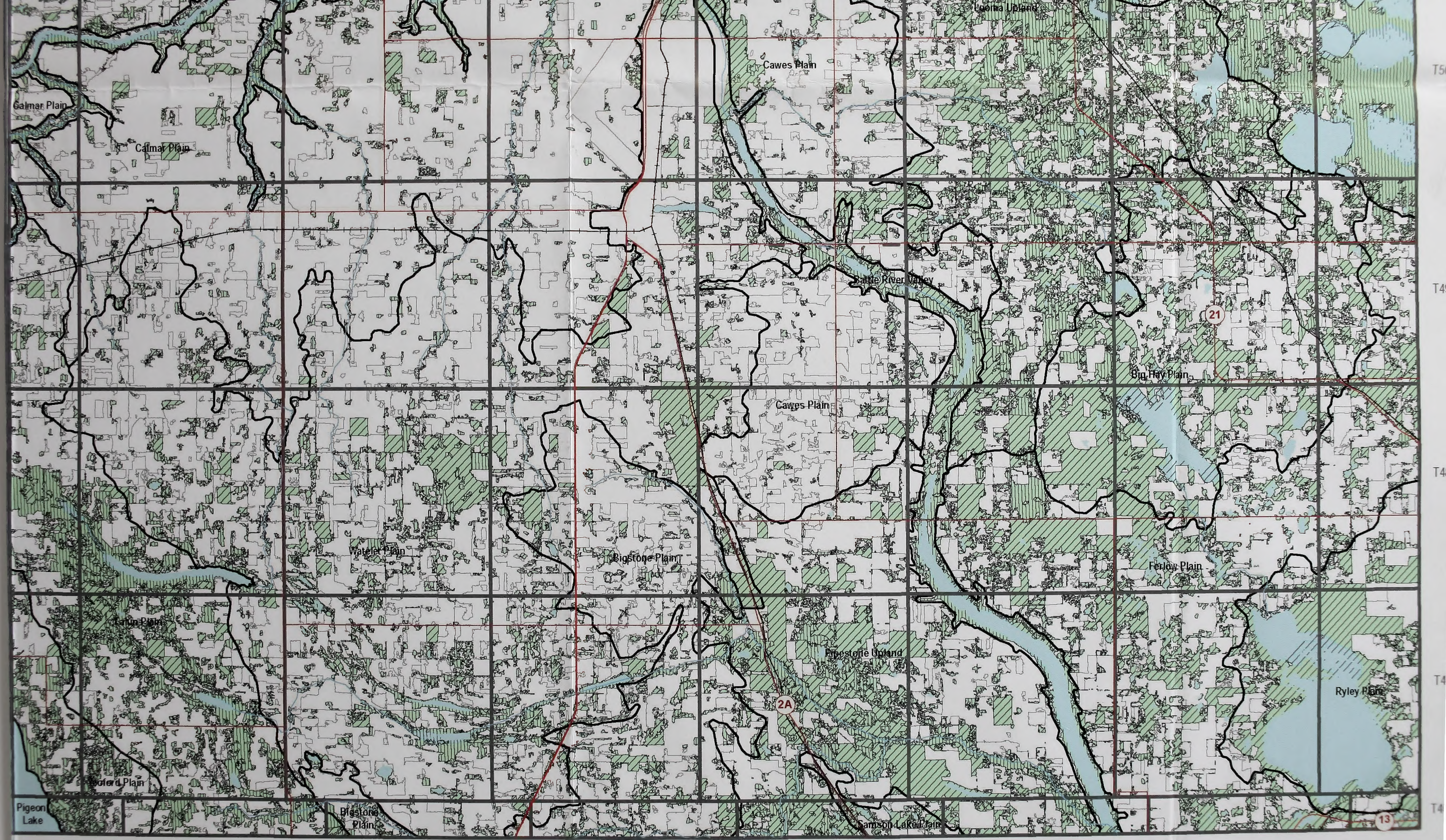



LIBRARY AND ARCHIVES CANADA
Bibliotheque et Archives Canada 